\begin{abstract}
UNIVERSIDADE DE SÃO PAULO
FACULDADE DE FILOSOFIA LETRAS E CIÊNCIAS HUMANAS DEPARTAMENTO DE TEORIA LITERÁRIA E LITERATURA COMPARADA

PROGRAMA DE PÓS-GRADUAÇÃO EM TEORIA LITERÁRIA E LITERATURA COMPARADA
\end{abstract}

Lívia Bueloni Gonçalves

Em busca de Companhia: $O$ universo da prosa final de Samuel Beckett

Versão corrigida

São Paulo

2014 


$$
\text { UNIVERSIDADE DE SÃO PAULO }
$$

FACULDADE DE FILOSOFIA LETRAS E CIÊNCIAS HUMANAS DEPARTAMENTO DE TEORIA LITERÁRIA E LITERATURA COMPARADA PROGRAMA DE PÓS-GRADUAÇÃO EM TEORIA LITERÁRIA E LITERATURA COMPARADA

\title{
Em busca de Companhia: O universo da prosa final de Samuel Beckett
}

\author{
Lívia Bueloni Gonçalves
}

Tese apresentada ao programa de Pós-Graduação em Teoria Literária e Literatura Comparada da Faculdade de Filosofia, Letras e Ciências Humanas da Universidade de São Paulo, para a obtenção do título de Doutora em Letras.

Área de Concentração: Teoria Literária e Literatura Comparada

Orientação: Fábio Rigatto de Souza Andrade

São Paulo

2014 
A meus pais, Márcio (in memoriam) e Soemes. 


\section{Agradecimentos}

Voyez-vous, la route est longue quand on chemine tout

seul...

Beckett, En attendant Godot

Felizmente, ao longo de minha trajetória no doutorado, tive a inestimável companhia de amigos, colegas e familiares, apoiando, de diversas formas, um caminho nem sempre fácil. Além de agradecer, dedico este trabalho a todos vocês.

À minha querida família, que atravessou, ajudou e enfrentou comigo os altos e baixos deste percurso. Agradeço principalmente à minha avó Zenith; à minha mãe Soemes e às minhas tias Marilena e Marisa. Ao meu orientador, Fábio de Souza Andrade, pela apresentação de todo esse mundo beckettiano, pela generosidade e por tudo que pude aprender e absorver em um convívio de tantos anos.

Aos amigos próximos e sempre presentes, pela força e pelas conversas inspiradoras em muitos momentos - Daniela Gonçalves, Eduardo Parisi, Hugo Neto, Simone Paulino, Kátia Suelotto, Márcia Machado, Rita Pisano.

Aos amigos do Grupo de Estudos Samuel Beckett, cujas discussões foram fundamentais para o aprofundamento deste trabalho. Agradeço especialmente a Luciano Gatti, Cláudia Maria de Vasconcellos, Talita Mochiute Cruz e Francisco Merçon pelas conversas beckettianas em diversas ocasiões.

Aos amigos do Grupo de Estudos O romance e suas crises que, em debates literários sempre tão produtivos, me estimularam a refletir sobre muitos aspectos desta tese. 
À Ana Helena Souza e Sandra Guardini Vasconcelos, pelas valiosas observações em meu exame de qualificação.

Ao professor Mark Nixon, diretor da Beckett International Foundation, que me acolheu durante a estadia na Universidade de Reading, possibilitando o acesso ao acervo da fundação.

Agradeço à FAPESP pela bolsa de doutorado concedida no país e também pela bolsa BEPE, através da qual pude realizar parte da pesquisa nos arquivos de Beckett em Reading, no Reino Unido. Agradeço também ao CNPq pela bolsa concedida nos primeiros meses do doutorado. 


\section{Resumo}

O presente trabalho realiza uma leitura da chamada segunda trilogia em prosa de Samuel Beckett composta pelos textos Company (1980), Ill Seen Ill Said (1981) e Worstward Ho (1983), com especial atenção para a obra Company. Tais textos fazem parte da prosa final do autor, marcada pelo hibridismo de gêneros e por um intenso questionamento da linguagem e da representação literária. Destacando as características desta fase procuramos argumentar que, em meio a todos os experimentos do narrador beckettiano, há um mecanismo de busca de companhia na própria narrativa, tema que atravessa diversos trabalhos de Beckett e se evidencia com a publicação de Company. A necessidade de companhia através do ato de narrar, contudo, processa-se de forma ambígua e conflituosa.

Palavras-chave: Beckett; companhia; segunda trilogia beckettiana; prosa final beckettiana; Company; IIl Seen Ill Said; Worstward Ho. 


\section{Abstract: Searching for Company. The universe of Samuel Beckett's late prose.}

This dissertation presents a reading of Samuel Beckett's so-called second trilogy in prose comprising the works Company (1980), III Seen IIl Said (1981), and Worstward Ho (1983), with special focus on Company. These texts belong to the author's late prose, characterized by a mixture of genres and the intense questioning of both language and literary representation. While highlighting the specificities of this period, we argue that among all the experiments of the Beckettian narrator there is a mechanism that seeks for company within the very narrative - a theme present in many of Beckett's works, which is further stressed by the publication of Company. The need for company through the act of narrative, however, unfolds in an ambiguous and conflicted manner.

Keywords: Beckett; company; Beckett's second trilogy; Beckett's late prose; Company; Ill Seen IIl Said; Worstward Ho. 
"Lutar com palavras parece sem fruto Não têm carne e sangue... Entretanto, luto". Carlos Drummond de Andrade, O lutador. 


\section{Sumário}

Nota sobre o bilinguismo do autor e as traduções utilizadas - p.10

Introdução ou "O misterioso homem de impermeável" - p.13

Homero... Joyce.Beckett... Vila-Matas... - p.13

Beckett para iniciados - p.25

I. Do "como dizer" ao "mal dizer": as transições na prosa de Samuel Beckett - p.28

1.1. As fases da prosa beckettiana - p.29

1.2. A crítica e as fases - p.49

1.3. Discutindo a periodização - p.53

II. No manicômio do crânio: a "segunda trilogia" beckettiana - p. 62

2.1. Company, imaginação soberana na escuridão - p.63

2.2. Ill Seen IIl Said - O olho enevoado - p.77

2.3. Worstward Ho - Mente incansável - p.98

2.4. "Falhando melhor". O embate com a palavra - p.107

III. Em busca de Companhia. "E você como sempre esteve. Só" p. 111

3.1. O narrador-voz - p.115

3.2. "Alone together" - ficção como companhia - p.131

3.3. "Confusão também é companhia até certo ponto" - p.139

3.4. Conciliação ou novo impasse? - p.144

Bibliografia - p.149 


\section{Nota sobre o bilinguismo dos textos e traduções utilizadas}

Da fase final da prosa de Beckett, trataremos das obras Company (1980), Mal Vu Mal Dit (1981) e Worstward Ho (1983). Com exceção do segundo título mencionado, escrito originalmente em francês e depois traduzido pelo próprio autor para o inglês como III seen Ill said (1981), os outros dois textos foram compostos em inglês. Para manter a unidade linguística dessa tríade, optei por usar citações de IIl seen IIl said ao invés de Mal Vu Mal Dit, na segunda parte da tese.

O bilinguismo beckettiano é um assunto amplamente discutido entre os estudiosos do autor ${ }^{1}$. Independentemente de qual língua tenha sido utilizada para criar uma obra, o que poderia conferir um caráter de originalidade à Mal Vu Mal Dit, sabemos que o autor trabalhou incessantemente nessas "traduções" mantendo intactos o universo e as questões trazidas por cada obra. É claro que cada língua representa em si um universo próprio, tanto estilístico como cultural e Beckett lidou com essas questões quando traduziu seus textos, buscando os termos mais adequados, substituindo expressões, suprimindo trechos. Ele até mesmo joga com seu leitor, modificando as possíveis interpretações de algumas passagens, dependendo do idioma em que se realiza a leitura - artifício passível de uso somente no caso da autotradução².

\footnotetext{
${ }^{1}$ Ver como exemplo a coletânea de ensaios Beckett Translating/Translating Beckett. (Friedman, Alan W. Rossman, Charles \& Sherzer, Dina (Ed). Beckett Translating/Translating Beckett. Pennsylvania: Pennsylvania State University Press, 1987.) Ver também o capítulo IV do livro de Ana Helena Souza: A Tradução Como um Outro Original. Como é de Samuel Beckett (Rio de Janeiro: 7Letras, 2006)

${ }^{2}$ Ver o ensaio de Brian T. Fitch sobre o cotejo entre Company e Compagnie intitulado "The Relationship Between Compagnie and Company: One Work, Two Texts, Two Fictive Universes". In: Friedman, A., Rossman, C. \& Sherzer, D., op. cit.
} 
Considerar o bilinguismo do autor é algo fundamental no estudo de sua obra. É sabido que a adoção do francês nos anos 40 foi um grande ponto de virada em seu trabalho. Na fase final de sua prosa, entretanto, há um retorno à língua materna com a predominância de textos escritos originalmente em inglês. Além da preocupação com a uniformidade, este também é um motivo que nos fez optar pelo trabalho com essa língua nestes textos. Isso não significa que os textos em francês não venham a ser utilizados. Eles serão muito importantes para marcar contrastes e discutir alguns aspectos das obras.

Vale enfatizar que não podemos considerar IIl Seen IIl Said uma mera tradução de Mal Vu Mal Dit. Beckett iniciou a tradução para o inglês antes mesmo de finalizar a obra em francês. O mesmo ocorreu, em sentido inverso, na composição de Company e Compagnie. A tradução francesa foi iniciada antes mesmo da versão final do texto em inglês. Talvez a palavra ideal neste caso seja "recriação" ou "criação conjunta". A ideia transmitida aqui é a de um autor que tem duas línguas à sua disposição e compõe uma obra com duas roupagens diferentes.

Recentemente, as obras da segunda trilogia foram traduzidas para o português. Quando elas forem citadas, a tradução para nossa língua virá em nota de rodapé. Para Company e Worstward Ho, usaremos a tradução de Ana Helena Souza (Beckett, S. Companhia e outros textos. São Paulo: Globo, 2012). Para Ill Seen Ill Said, a tradução utilizada será a de Eloísa Araújo Ribeiro realizada a partir de Mal Vu Mal Dit. (Beckett, S. O despovoador. Mal Visto Mal Dito. São Paulo: Martins Fontes, 2008).

Pelo fato de Mal Visto Mal Dito ter sido traduzida a partir do francês (não há nenhuma tradução publicada de IIl Seen IIl Said para o português) algumas diferenças poderão ser notadas na comparação com o texto em inglês. Ainda assim, acredito ser válida a citação de 
uma bem-sucedida tradução do texto para nossa língua, tendo em vista a extrema complexidade que esses textos trazem para a atividade da tradução.

Há diversas obras de Beckett ainda não traduzidas para o português e, no caso desses trechos, eu mesma ofereço uma tradução em nota de rodapé. O mesmo vale para os textos críticos citados. 
Beckett, que amava o mundo das palavras e amava o jogo, levou uma vida de romances cada vez mais curtos, mais ínfimos, obras cada vez mais despojadas, mais descarnadas. Sempre rumo ao pior. "Nomear não, nada é nomeável dizer, não, nada é dizível, então o quê, não sei, não devia ter começado". Um obstinado caminho para o silêncio. "Assim rumo ao menos ainda. Enquanto ainda tênue. $O$ tênue sem atenuar. Ou atenuado ao mais tênue ainda. Até o tênue tenuíssimo. O minimíssimo do tênue tenuíssimo".

Mudou de língua para empobrecer sua expressão. E afinal seus textos pareciam cada vez mais depurados. Delírio lúcido da miséria. Vivendo sempre no obstruído, no precário, no inerte, no disforme, no incerto, no rígido, no aterrorizador, no inóspito, no nu, no enfermiço, no vacilante, no desguarnecido, no exilado, no inconsolável, no lúdico. Beckett magérrimo e fumando no quarto de Le Tiers Temps, um asilo de velhos de Paris. Os bolsos cheios de biscoitos para as pombas. Retirado como um ancião qualquer sem família a um lar de idosos. Pensando no mar da Irlanda. À espera da escuridão definitiva. "Melhor assim, afinal de contas que as penas se percam e que volte o silêncio. Afinal de contas, é como sempre se esteve. Só".

Enrique Vila-Matas, em Dublinesca

\section{Homero... Joyce. Beckett... Vila-Matas...}

Capítulo seis de Ulisses (1922). Enterro de Paddy Dignam. Em meio ao sepultamento, Leopold Bloom vê um homem desconhecido, apartado do grupo que chega unido ao cemitério de Glasnevin: "Ora quem é aquele sujeito estranho desengonçado ali de capa impermeável? Ora quem é ele eu gostaria de saber? Ora eu daria uma bagatela para saber quem ele é. Sempre surge alguém com quem você nunca sonhou" ${ }^{3}$.

Em Dublinesca (2010), romance de Enrique Vila-Matas, o protagonista Riba, editor aposentado e um pouco deprimido, planeja

\footnotetext{
3 Joyce, James. Ulisses. Trad. Bernardina da Silveira Pinheiro. Rio de Janeiro: Alfaguara/Objetiva, 2007, p. 144.
} 
uma viagem a Dublin no período do Bloomsday e na companhia de poucos amigos: "Vou a Dublin para um funeral da era da imprensa, da era dourada de Gutenberg", ele comunica à esposa.

Algum tempo depois, Riba e seus amigos aparecerão no cemitério de Glasnevin, em pleno Bloomsday, fazendo referência ao sexto capítulo do romance de James Joyce. Para Riba, Ulisses é "o romance dublinense por excelência e um dos picos da era da imprensa" que, de acordo com ele, teria chegado ao seu ocaso. Como não poderia deixar de acontecer neste jogo literário proposto por Vila-Matas, o misterioso homem de impermeável também aparece para Riba e é associado a outro grande escritor irlandês:

O olhar de Riba circula pelos presentes e se detém em um grupo que não é do pub, mas do campo-santo. Perto dessa gente, como surgido do nada, aparece um sujeito alto e deselegante, solitário. Não está com ninguém. De onde terá saído? É o mesmo sujeito que ele viu esta manhã na Meeting House. Parece Samuel Beckett quando jovem. Óculos redondos de tartaruga. Rosto ossudo e enxuto. Olhos de águia, de pássaro que voa alto, que tudo vê inclusive de noite. Cobre-se com uma desastrosa gabardina bege e olha Riba com atenção intensa, como se estivesse sentindo que seu espírito voa e também como se não quisesse passar certa obscura infelicidade que se desprende de seu rosto de pássaro. [...]

Riba continua olhando o desconhecido de impermeável e, logo depois, o vê entrar lentamente na névoa e então se apagar, desaparecer dentro dela. Não o vê de novo. Que terá acontecido com o sujeito tragado pela bruma? Drácula também desaparecia assim. Mais que isso. Drácula tinha a capacidade de se converter em névoa. Foi só ele quem o viu? Volta a perguntar a Ricardo se ele registrou a presença de um jovem com um impermeável que aquela manhã também estava na Meeting House. "Que enigma por si mesmo complexo Bloom de pé, voluntariamente apreendendo, não compreendendo, saindo recolhendo roupas múltiplas, multicores, multiformes?" Que facilidade, por certo, para se volatizar, qual Drácula na névoa. Nesse mesmo cemitério, em outros tempos, Bloom chegou a ver o seu criador.

Se tenho um autor, é possível que tenha esse rosto, pensa.

-Não, mas você já sabe - diz Ricardo - Sempre aparece alguém que nunca se espera ${ }^{4}$.

\footnotetext{
${ }^{4}$ Vila-Matas, Enrique. Dublinesca. Trad. José Rubens Siqueira. São Paulo: Cosac Naify, 2011, p. 246-7.
} 
A aparição fantasmagórica de Beckett em um romance contemporâneo que retoma Ulisses que, por sua vez, parodia a Odisseia de Homero, não pode passar despercebida. Estamos diante de etapas muito marcantes na história da ficção, retomadas por VilaMatas em um jogo lúdico de referências literárias. O surgimento de um homem parecido com Beckett no momento em que o grupo de amigos deixa o cemitério tampouco está ali ingenuamente, uma vez que a ideia de "morte da literatura" perpassa a própria história de Riba, que se considera um editor fracassado. O livro faz uma transição do mundo de Joyce ao mundo de Beckett fornecendo um chão literário para que Riba realize suas reflexões. Como grande amante dos livros, ele se lamenta por não ter descoberto e editado um grande autor de sua época, questiona a existência dessa figura e vive citando antigos escritores. Parte de sua angústia deriva dessa frustração. A partir de um sonho e da fixação de que deve celebrar tanto o Bloomsday como o fim da era Gutenberg, parte para Dublin.

Há várias menções ao mundo beckettiano em Dublinesca, além de citações reconhecíveis da obra do autor, muitas vezes alteradas. 0 nome da esposa de Riba, por exemplo, é Célia, assim como a namorada de Murphy. O livro que acompanha o editor em sua viagem é a famosa biografia de Beckett escrita por James Knowlson, Damned to Fame (1996). Após a visão do homem na saída do cemitério, Riba vê-se cada vez mais imerso em um mundo insólito e beckettiano, no qual a ficção mescla-se à sua vida e torna-se indissociável dela para o leitor. Em um ponto alto da narrativa para os fãs de Beckett, o editor conhece dois franceses em um bar chamados Verdier e Fournier, descobre através deles que o tal duplo do autor era relativamente famoso em Dublin e que, para alguns, era conhecido como Godot, para outros, como Malachy Moore mas que, na verdade, o sujeito é o próprio Beckett que vaga por ali. 
A presença marcante em grande parte desta obra, contudo, é a de James Joyce. Os momentos beckettianos, entretanto, denotam que o escritor espanhol é um leitor atento e admirador de Beckett. Vila-Matas não é o único. Beckett costuma ser citado por diversos escritores e críticos como o representante de um marco na história literária, como aquele que levou a literatura a seu ponto mais extremo, provocando uma intensa reflexão sobre os possíveis caminhos a se seguir com ela. Esse é um dos motivos pelos quais Beckett paira como um espectro na graciosa Dublinesca de VilaMatas.

Partindo do mundo literário para o mundo da teoria, seguindo a ideia do espectro que paira, Beckett é citado por Peter Boxall como o escritor que representa a ponte entre os modernistas e os contemporâneos. No livro Since Beckett. Contemporary Writing in the Wake of Modernism (2009), o crítico analisa o que considera uma "influência" de Beckett em uma gama de autores de tradições diversas, indo do conterrâneo irlandês John Banville a Thomas Bernhard, W.G. Sebald, J.M. Coetzee, Saul Bellow e Don de Lillo. Partindo da obra de Beckett como referência e fazendo um movimento para trás e para frente, o objetivo de Boxall é mostrar como o escritor irlandês realiza uma ligação entre passado e futuro, colocando "as formas herdadas de Joyce e Proust em um contato particular com o contemporâneo" ${ }^{5}$.

Citando dois exemplos estudados por Boxall, em Sebald, a presença de Beckett se daria pelo aspecto formal. Ele vê a cadeia de vozes narrativas no romance Austerlitz (2001) como herdeira do jogo

\footnotetext{
${ }^{5}$ Boxall, Peter. Since Beckett. Contemporary Writing in the Wake of Modernism. London/New York: Continuum International Publishing Group, 2009, p. 16.
} 
de vozes que marca a prosa de Beckett a partir do romance Comment C'est (1961). Para o crítico, a fragmentação característica de Beckett se acomodaria a uma narrativa centrada no Holocausto. Uma relação diferente ocorreria no romance Dangling Man (1944), de Saul Bellow, no qual ele aponta o que seria uma resposta ao isolamento beckettiano. O protagonista desta obra - Joseph - a quem o crítico compara com Murphy, decide sair de seu quarto e lutar por seu país na Segunda Guerra Mundial, enfrentar o mundo ao invés de isolar-se dele.

O crítico vê a sombra de Beckett por trás de diversas obras desses autores, tanto em aspectos formais como temáticos e cita o escritor irlandês como uma peça-chave para se entender a história literária a partir do século XX. Ainda que em alguns momentos a presença de Beckett se baseie em análises bastante pessoais de Boxall, a obra tem o grande mérito de tentar situar Beckett em um amplo contexto cultural e contemporâneo, algo pouco comum dentro da crítica do autor. Este não é o único trabalho do pesquisador sobre Beckett. Ele já havia editado uma obra sobre a recepção crítica das peças En attendant Godot (1952) e Fin de partie (1957), mapeando as correntes através das quais o teatro de Beckett foi interpretado entre os anos 50 e $90^{6}$. Apesar de meu trabalho estar centrado na prosa do autor, vale a pena mencionar um importante debate da crítica teatral, uma vez que a maioria dos estudiosos da obra de Beckett, da mesma forma com a qual o autor transitou entre os gêneros, também transitou entre as análises de prosa e drama.

Para Boxall, a recepção crítica do drama beckettiano deriva basicamente de duas vertentes: a primeira na esteira de Martin Esslin; a segunda na esteira de Adorno.

\footnotetext{
${ }^{6}$ Ver Boxall, Peter (Ed). Samuel Beckett. Waiting for Godot/Endgame. Cambridge: Icon Books Ltd., 2000.
} 
Esslin incluiu Beckett na categoria do "teatro do absurdo" juntamente com dramaturgos como Arthur Adamov, Eugène Ionesco, Jean Genet, e Harold Pinter ${ }^{7}$. Para Esslin, no século XX, tais autores teriam cunhado uma forma dramática especial convertendo a falta de sentido do mundo e da existência humana no próprio sentido de suas peças. De acordo com Boxall, porém, com este conceito, Esslin teria transformado a crítica que Beckett faz do humanismo ocidental em uma defesa do mesmo:

The universal reality that Esslin discovers in Beckett's drama, in which an individual confronts a confusing and irredeemable world with honesty, bravery and poetry, is a cornerstone of the Western bourgeois ideology in which his critique is steeped: the world may be bleak and difficult, but there is nothing we can do about it, so we must keep on going with humour and humility, stoically accepting the status quo as the given and immuttable condition of humanity. ${ }^{8}$

Já Adorno teria uma visão oposta à de Esslin. Em sua análise de Fin de partie, haveria a defesa de que "a falta de sentido não pode ser transformada em sentido pela crítica, mas deve ser examinada na condição e no momento de sua falta de sentido" ${ }^{9}$. Na interpretação do filósofo alemão, Fin de partie trataria da decadência da cultura ocidental em um momento de triunfo do capitalismo:

Endgame presents us with a voiceless reflection on such a catasthrophe - a dramatic urge towards a condemnation of what has become of culture, which cannot find a voice and whose only mode of expression is silence. This silent verdict on twentieth century culture

\footnotetext{
7 A primeira edição da obra The Theatre of the Absurd é de 1961. Há uma edição brasileira de 1968. (Esslin, Martin. O Teatro do Absurdo. Trad. Bárbara Heliodora. Rio de Janeiro: Zahar, 1968)

8 "A realidade universal que Esslin encontra no drama de Beckett, no qual um indivíduo confronta um mundo confuso e irremediável com honestidade, coragem e poesia, é o pilar da ideologia burguesa ocidental na qual sua crítica está mergulhada: o mundo pode ser deserto e difícil, mas não há nada que possamos fazer quanto a isso, então devemos continuar com humor e humildade, aceitando estoicamente o status quo como a condição inerente e imutável da humanidade". (Boxall, op. cit., p. 37)

${ }^{9}$ Idem, ibidem, p. 22.
} 
cannot be mediated or paraphrased by philosophy or by theory, because it is the inability of these discourses to deal with the depravity of post-Second World War culture that is the focal point of the play. ${ }^{10}$

Boxall comenta que, enquanto Esslin buscou elucidar, humanizar e positivizar o teatro beckettiano, Adorno mostrou-se contra essa prática, ressaltando que era preciso encontrar uma forma de crítica que acessasse a negatividade de Beckett sem comprometer a rejeição de seu trabalho a interpretações. Coerentemente, Boxall vê a crítica ao teatro beckettiano desenvolver-se entre esses dois polos: a tentativa de entender como o radicalismo beckettiano subverte e desconstrói instituições ideologicamente dominantes caminhando ao lado de uma tentativa oposta - interpretar sua forma dramática em si, assumindo que sua arte é apolítica e benigna ${ }^{11}$.

Em uma variação da vertente de Esslin estariam críticos como Hugh Kenner e Ruby Cohn, mais focados na análise dos aspectos formais da obra de Beckett, compartilhando a visão de que seu drama trata de verdades universais sobre a condição humana em tempos de crise cultural. A mesma linha teria gerado um outro tipo de abordagem - aquela focada no questionamento em torno das noções de significado, identidade e subjetividade, além de explorar a dinâmica da linguagem e da representação. Aqui, Boxall coloca estudiosos como Wolfgang Iser, Steven Connor, Leslie Hill, Mary Bryden e Carla Locatelli, que desenvolveram suas teorias a partir da exploração pessoal de um ou vários desses temas.

A tendência em ver possibilidades políticas na obra de Beckett teria ficado restrita à crítica de língua alemã. No entanto, Boxall vê

10 Fim de partida apresenta-nos uma reflexão muda sobre tal catástrofe - um impulso dramático na direção da condenação do que aconteceu com a cultura, que não pode encontrar uma voz e cujo único modo de expressão é o silêncio. Este veredito silencioso sobre a cultura no século $X X$ não pode ser mediado ou parafraseado pela filosofia ou pela teoria, pois a inabilidade desses discursos para lidarem com a depravação da cultura pós-Segunda Guerra Mundial é o ponto central da peça (Idem, ibidem, p. 40-1).

${ }^{11}$ Idem, ibidem, p. 50. 
nas leituras pós-coloniais da obra do autor, como as de Declan Kiberd, uma herança da visão de Adorno. Kiberd interpreta En attendant Godot e Fin de partie como uma forma de protesto dos colonizados contra seus colonizadores em um contexto que chamaria a atenção para as relações entre Irlanda e Inglaterra ${ }^{12}$.

A fortuna crítica do autor é tão vasta quanto as análises de sua obra e estende-se para além dos nomes mencionados por Boxall . No que se refere à prosa, a importância de Beckett está diretamente ligada à publicação da chamada trilogia romanesca do pós-guerra composta pelos romances Molloy, Malone Meurt (1951) e L'innommable (1953). Esses romances foram escritos na mesma época em que En attendant Godot e Fin de partie e, da mesma forma com a qual essas peças impactaram a história do drama, os romances também causaram muita discussão no plano da prosa. $O$ ensaio de Adorno tem muita relevância nos estudos beckettianos pois chama a atenção não apenas para a ruptura estética associada ao autor, mas também para sua ligação com o momento histórico do pós-guerra, algo que também vale para a composição desses romances.

A trilogia romanesca coloca Beckett como uma das referências para a crise da narrativa no século XX. Ao final da leitura dos três romances, temos a impressão de que nenhum rastro de história ficou em pé. Foco narrativo, tempo, espaço, personagens e enredo esfumaçam-se na gradativa confusão que toma conta dos narradores dessas obras. No último romance da tríade, as tentativas de contar uma história encontram-se completamente destruídas. Apesar do romance sempre ter sido considerado um gênero instável, a particularidade de Beckett está na radicalidade com a qual ele apresenta seus questionamentos, sempre apontando para uma incapacidade de narrar, para o impasse, para uma dissolução das

${ }^{12}$ A obra citada de Kiberd é Inventing Ireland (London: Jonathan Cape, 1995). 
formas e para uma crise aguda da representação da realidade. Quem conhece a prosa do autor pós-trilogia, guardadas as especificidades de cada trabalho, sabe que a luta com a palavra e com a narrativa transforma-se justamente no motor dessas obras.

A última frase de L'innommable tornou-se o próprio mote do narrador beckettiano - "é preciso continuar, não posso continuar, vou continuar". E ele, de fato, continua, ou melhor, "segue adiante", para usar agora a expressão central de uma das últimas obras do autor Worstward Ho (1983) - e começar a se aproximar do centro de nosso estudo.

$\mathrm{Na}$ tese que segue, os estudiosos com os quais dialogo são, em sua maior parte, da tradição de língua inglesa ou francesa, línguas nas quais a obra do autor mais se difundiu e produziu análises. Dentro da vasta crítica da obra de Beckett, os textos foram selecionados na medida em que forneciam contribuições frutíferas e alinhadas com nossa análise dos textos literários. John Pilling, James Knowlson, Enoch Brater, Stanley Gontarski e Mark Nixon, por exemplo, são fontes de referência marcantes na crítica beckettiana e muitos deles serão aqui citados e comentados. Somam-se a eles nomes que também se dedicaram com frequência à análise da obra de Beckett tais como Alain Badiou, Pascale Casanova, Maurice Blanchot, Carla Locatelli, Marjorie Perloff, Frederik Smith e H. Porter Abbott, entre outros.

Há uma série de estudos recentes voltados para a análise do material dos arquivos de Beckett - diários, cartas, cadernos de anotação, manuscritos - espalhados por diversos locais ao redor do mundo, mas condensados em dois grandes centros: a Universidade de Reading, no Reino Unido, sede da Beckett International Foundation e o Harry Ransom Humanities Research Center, na Universidade de Austin, no Texas. Mark Nixon, Matthew Feldman e 
Dirk Van Hulle são alguns dos pesquisadores associados a esses estudos. Nixon e Van Hulle são os diretores do projeto Samuel Beckett Digital Manuscript que visa disponibilizar pela internet os manuscritos dos trabalhos do autor.

A recepção crítica de um autor como Beckett, contudo, extrapola fronteiras e atualmente tem interessados espalhados pelo mundo todo como apresenta o livro organizado por Nixon e Feldman, The International Reception of Samuel Beckett (2009). Nessa obra, pesquisadores falam sobre a recepção do autor em seus países: Estados Unidos, Alemanha, Irlanda, Espanha, China, Japão, Polônia etc. Não há um capítulo sobre a recepção brasileira ${ }^{13}$. Os estudos de Beckett por aqui, porém, vêm crescendo como demonstram os trabalhos do Grupo de Estudos Samuel Beckett, coordenado por Fábio de Souza Andrade e sediado na Universidade de São Paulo, mas com integrantes de diversas partes do país. Há uma série de traduções recentes da obra do escritor para o português, realizada por críticos de sua obra no Brasil, algo que contribui bastante para a acessibilidade em nossa língua de um autor extremamente complexo. Fábio de Souza Andrade traduziu o romance Murphy (2013) e as peças Esperando Godot (2005), Fim de partida (2002) e Dias Felizes (2010), publicados pela editora Cosac Naify. Ana Helena Souza traduziu os romances Molloy (2007) e O inominável (2009), além de Companhia (2012) e alguns textos em prosa da fase final beckettiana, publicados pela Editora Globo. Outras traduções ainda estão por vir. Beckett, também no Brasil, ainda é mais conhecido pelo seu trabalho como dramaturgo.

\footnotetext{
${ }^{13}$ Há, contudo, um artigo do diretor teatral Robson Correa de Camargo publicado em 2006 na revista Journal of Beckett Studies, importante publicação na área dos estudos beckettianos. O autor trata da recepção do teatro de Beckett no Brasil. (Ver Camargo, Robson Correa de. 50 Years of Beckett in the Brazilian Theatre. Journal of Beckett Studies, vol. 15, 2006). Fábio de Souza Andrade também escreveu sobre a recepção brasileira no artigo "Facing other windows: Beckett in South America". (Ver Andrade, Fábio de Souza. Facing other windows: Beckett in South America. In: Gontarski, S.E. (Ed.) The Edinburgh Companion to Samuel Beckett and the Arts. Edinburgh: Edinburgh University Press, 2014)
} 
Em relação à prosa, Fábio de Souza Andrade estudou detidamente os romances da trilogia do pós-guerra em seu livro Samuel Beckett. O Silêncio Possível (2001), outra importante fonte de referência para o desenvolvimento desta tese, uma vez que o objeto de nossa pesquisa é justamente o momento pós-trilogia. Sobre esta fase, há poucos estudos no Brasil.

Após esse longo, mas necessário preâmbulo, chegamos, enfim, ao assunto deste trabalho - uma leitura da prosa final de Beckett centrada nos textos da chamada "segunda trilogia beckettiana": Company (1980), Ill Seen Ill Said (1981) e Worstward Ho (1983), com particular atenção para a obra Company.

Procuramos argumentar que, em meio a toda dissolução que a prosa de Beckett opera, questionando formas, rompendo modelos, há um mecanismo de busca de companhia na própria narrativa, o que se tornaria evidente com a publicação de Company. Essa busca, no entanto, processa-se de forma ambígua pois, ao mesmo tempo em que a narrativa é alvo de ataque e desconfiança, há uma dependência do narrador em relação a ela, o que impossibilita que ele alcance o tão desejado silêncio. A voz que surge em Company pode ser vista como a própria configuração desse processo em um texto literário, já que tanto pode apaziguar como torturar o sujeito que ouve, tanto contar uma história de vida como questionar o próprio sentido deste ato. A prosa de Beckett vai se construindo sobre essa ambiguidade e, nesse embate, ganha forma e caminha.

A ficção final do autor é composta por textos bem diferentes das obras da trilogia romanesca e coloca questões de ordem diversa. Não podemos sequer precisar o gênero aos quais pertencem, apesar de considerá-los "próximos da prosa". Com o decorrer da leitura, ficará clara a aproximação destes textos com a lírica e até mesmo com o drama, mostrando que o autor buscou explorar os diversos 
recursos ao seu alcance. Beckett era ligado a várias artes e essa diversidade refletiu-se em seu trabalho. Especialmente nessa última fase, há peças semelhantes a textos em prosa e vice-versa. No entanto, as dúvidas e os questionamentos do narrador continuam presentes nas novas configurações que a ficção de Beckett assume. 0 universo de sua prosa final tem um caráter mais hermético, voltado para as elucubrações da mente no momento em que cria ou, no caso de Beckett, tenta criar.

Privilegiando a análise das tentativas do narrador em contar histórias, a tese realiza um movimento de afunilamento, do geral ao particular, e está dividida em três partes.

Na primeira - Do "como dizer" ao "mal dizer": as transições na prosa de Samuel Beckett - tratamos das três fases da prosa do autor. Neste momento, procuramos mostrar o percurso do narrador desde as primeiras obras de ficção de Beckett, passando pela relação com James Joyce, pela mudança de idioma, a adoção do narrador em primeira-pessoa e pelas características centrais da última fase da prosa do autor.

Na segunda parte - No manicômio do crânio: a "segunda trilogia" beckettiana - abordamos as três obras reunidas sob tal denominação: Company, Ill Seen Ill Said e Worstward Ho. Aqui, o objetivo é comentar cada um dos textos, buscando semelhanças e diferenças, de forma a caracterizar o universo da prosa final, relacionando-o com outros trabalhos de Beckett.

A terceira parte - Em busca de Companhia. "E você como sempre esteve. Só" - destaca esta obra das outras duas e procura por suas particularidades. A partir da análise de alguns elementos estruturais do texto, como a do narrador-voz, aproximamo-nos da ideia da ficção como companhia, de modo a discuti-la. 


\title{
Beckett para iniciados
}

\author{
Mas, afinal, "quem é o leitor da prosa final de Beckett?" \\ pergunta-se Enoch Brater em seu artigo sobre Worstward $\mathrm{Ho}^{14}$. O \\ tom de perplexidade da questão aponta para a estranheza que esses \\ textos apresentam à primeira vista. Como abordar, por exemplo, uma \\ obra que começa dessa forma:
}

On. Say on. Be said on. Somehow on. Till nohow on. Said nohow on.

Say for be said. Missaid. From now say for be missaid.

Say a body. Where none. No mind. Where none. That at least. A place. Where none. For the body. To be in. Move in. Out of. Back into. No. No out. No back. Only in. Stay in. On in. Still.

All of old. Nothing else ever. Ever tried. Ever failed. No matter. Try again. Fail again. Fail better ${ }^{15}$.

Worstward Ho é um bom exemplo da radicalidade que a prosa de Beckett assume em sua fase final. Se os romances do pós-guerra questionavam o ato de narrar e a própria autoridade da voz narrativa, os textos finais passam a discutir intensamente o papel da linguagem, sua capacidade de representação e transmissão de conhecimento. Como podemos observar pelo trecho acima, o

\footnotetext{
${ }^{14}$ Brater, Enoch. Voyelles, Cromlechs and the Special (W) rites of Worstward Ho. In: Acheson, James \& Arthur, Kateryna. Beckett's Later Fiction and Drama. Texts for Company. London: Macmillan Press, 1987.

${ }^{15}$ Beckett, Samuel. Worstward Ho. In: Samuel Beckett. The Grove Centenary Edition. Vol. IV. Poems, Short Fiction, Criticism. New York: Grove Press, 2006, p. 471.

Adiante. Dizer adiante. Ser dito adiante. De algum modo adiante. Até que de nenhum modo adiante. Dito de nenhum modo adiante.

Dizer por ser dito. Dito mal. Desde agora dizer por ser dito mal.

Dizer um corpo. Onde nenhum. Nenhuma mente. Onde nenhuma. Isso pelo menos. Um lugar. Onde nenhum. Para o corpo. Estar nele. Mexer-se nele. Fora dele. De volta a ele. Não. Não fora. Não de volta. Somente nele. Ficar nele. Adiante nele. Parado.

Tudo de outrora. Nada mais nunca. Nunca tentado. Nunca falhado. Não importa. Tentar de novo. Falhar de novo. Falhar melhor.

(Beckett, S. Pra frente o pior. In: Companhia e outros textos. Trad. Ana Helena Souza. São Paulo: Globo, 2012, p. 65)
} 
narrador avança aos solavancos em sua tentativa de configurar uma obra. Worstward Ho exige uma outra postura do leitor. O texto voltase contra a própria palavra e não permite que o acompanhemos dentro da perspectiva de um encadeamento lógico. Não há mais como seguir os rastros de uma narrativa, apenas imagens esparsas e incompletas. Beckett coloca-se em busca de uma outra forma de comunicação, de um outro tipo de discurso, ou melhor, procura por uma forma que comporte sua própria insatisfação com as possibilidades que a palavra oferece. Tal objetivo é perseguido de forma intensa.

Brater argumenta que, em Worstward Ho, a palavra é protagonista e a linguagem, antagonista. No mesmo artigo, o crítico ainda diz que poucos, além dos "já iniciados", ousariam aventurar-se por um caminho no qual "a linguagem como veículo de comunicação parece ter ruído completamente". Redução, fragmentação, metalinguagem, necessidade de dizer e mal dizer a palavra e o desejo de falhar são marcas dessa obra, a mais drástica das três estudadas. Apesar da ideia de destruição, algo poderoso se constrói quando o autor lida com as ruínas da linguagem e a partir delas, surge um universo extremamente elaborado, instigante, exigente com o leitor e que nunca se desvela por inteiro.

Entrar nesse universo final pressupõe um conhecimento anterior da obra beckettiana, uma vez que as opções narrativas e as imagens utilizadas são frutos de um contexto maior com o qual o autor veio trabalhando no decorrer de sua trajetória. A leitura de Worstward Ho depende, certamente, de que o leitor conheça os embates prévios do narrador beckettiano. Daí a ideia de leitor iniciado.

A imagem de Beckett "tragado pela bruma" que Riba vê em Dublinesca traz muito da atmosfera da prosa final e da própria ideia de autor obscuro associada a Beckett. Obscuro, inquietante e, 
"plagiando" Adorno, resistente a interpretações. A bruma, no entanto, pode se dissipar um pouco e revelar algo mais do "misterioso homem de impermeável". Um sujeito deitado no escuro que ouve uma voz, uma senhora isolada em sua cabana, uma mente incansável tentando criar. O desejo desta "iniciada" é trazer um pouco de luz para o universo da prosa final de Samuel Beckett. 


\title{
I - DO "COMO DIZER" AO "MAL DIZER": AS TRANSIÇÕES NA PROSA DE SAMUEL BECKETT
}

\begin{abstract}
Viver. Falo sem saber o que quer dizer tal coisa. Tentei fazê-lo ignorando o que fazia. Talvez eu tenha vivido, sem saber. Me pergunto por que fico falando nessas coisas todas. Ah, sim, é para não morrer de tédio. Viver e fazer viver. Não vale a pena culpar as palavras. Elas não são mais vazias do que aquilo que carregam. Depois do fracasso, o consolo, o repouso, comecei de novo a querer viver, fazer viver, ser outrem, em mim, em outrem. Como tudo isso é falso. Não tenho tempo para explicar. Jamais consegui nada parecido. Comecei de novo. Mas, pouco a pouco, com uma outra intenção. Não mais a de ter sucesso, mas a de fracassar.
\end{abstract}

Samuel Beckett, Malone Morre

A obra em prosa de Samuel Beckett passou por uma série de transformações desde a estreia do autor no mundo literário. Do caminho iniciado com o livro de contos More Pricks than Kicks (1934) até seus últimos trabalhos ficcionais - entre os quais destacaremos Company (1980), Ill Seen IIl Said (1981) e Worstward Ho (1983) uma longa e questionadora jornada narrativa foi percorrida ${ }^{16}$.

A fala de Malone, expressa no segundo romance da notável trilogia romanesca do pós-guerra, expõe um tema caro ao autor, presente sobretudo a partir das obras narradas em primeira-pessoa e da adoção da língua francesa - a ideia do fracasso, da falha. O tema não deve ser entendido como uma desistência da tarefa de narrar, muito pelo contrário. Na terra do "I can't go on, I' II go on", um dos fascínios de se acompanhar a trajetória da prosa beckettiana está justamente na persistência do narrador, sob as mais diversas configurações que assume. Mesmo frustrado com as palavras, mesmo

\footnotetext{
${ }^{16}$ Este recorte foi feito considerando as obras mais conhecidas de Beckett. Sua produção em prosa é bastante extensa. O autor possui contos e textos literários anteriores a More Pricks than Kicks e também posteriores a Worstward Ho.
} 
insatisfeito com o que busca representar, ele continua. A narrativa é, afinal, sua grande companhia. Apresentar as etapas dessa caminhada é o foco da primeira parte desse trabalho.

\subsection{As fases da prosa beckettiana}

A ficção de Beckett costuma ser dividida em três fases principais. Na primeira, de língua inglesa, estão as primeiras obras do escritor, como o livro de contos More Pricks than Kicks e os romances Murphy (1938) e Watt (1953).

Neste começo, Beckett escreve em tom paródico sobre a vida de seus jovens protagonistas perambulando pela Irlanda (More Pricks than Kicks), por Londres (Murphy) ou tentando entender tanto o funcionamento da linguagem como as regras da misteriosa casa em que trabalha, caso de Watt. Especialmente nas duas primeiras obras, o estilo empregado pelo autor está longe da "linguagem empobrecida" que ele viria a buscar posteriormente e é frequentemente associado à literatura de James Joyce, escritor de quem Beckett fora muito próximo.

Um dos motivos que culminariam na decisão de adotar a língua francesa a partir da segunda fase foi justamente o desejo de se afastar da influência de Joyce e trilhar um caminho próprio, mais simples e objetivo ${ }^{17}$. Em uma entrevista de 1956, Beckett diria que queria trabalhar com a impotência e a ignorância, ao contrário de Joyce, que "tendia para a onisciência e a onipotência enquanto

\footnotetext{
${ }^{17}$ James Knowlson, biógrafo autorizado e amigo de Beckett, faz esse comentário ao analisar algumas das entrevistas concedidas pelo autor. Ver Knowlson, James. Damned to Fame. The life of Samuel Beckett. New York: Grove Press, 1996, p. 323-4.
} 


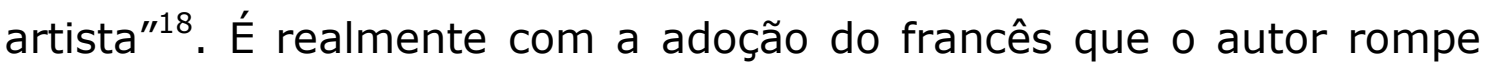
com essa primeira fase, passando a produzir textos que atingiriam seu ponto mais alto na escrita da trilogia romanesca composta por Molloy, Malone Meurt (1951) e L'innommable (1953).

Com esses três romances, Beckett passa a ser conhecido como um dos escritores mais relevantes do século XX. Na mesma entrevista mencionada, comentando seu retorno a Paris após a Segunda Guerra Mundial, o autor também declara que se sentia mais estimulado escrevendo em francês:

\begin{abstract}
Apesar de ter sido obrigado a fugir em 1942, consegui manter meu apartamento. Voltei para cá e comecei a escrever novamente, em francês. Senti vontade. Era uma experiência diferente de escrever em inglês. Era mais estimulante para mim, escrever em francês.
\end{abstract}

Escrevi toda minha obra muito rapidamente, entre 1946 e 1950. Desde então não escrevi mais nada. Ou pelo menos nada que me pareça de valor. A obra em francês levou-me a um ponto em que sentia estar dizendo a mesma coisa de novo, de volta ao começo repetidas vezes. Para alguns autores, a escrita fica mais fácil quanto mais escrevem. Para mim, fica mais difícil. Para mim, a área do possível fica cada vez mais restrita ${ }^{19}$.

É certo que a prática da língua francesa já fazia parte da rotina do autor desde cedo. Beckett trabalhou como Lecteur d'Anglais na École Normale Supérieure de Paris entre 1928 e 193020. Além disso, traduziu para o inglês poemas de diversos autores franceses como

\footnotetext{
${ }^{18}$ Esta declaração está na entrevista concedida a Israel Shenker em 1956. Ver Andrade, Fábio de Souza. Anexos. In: Samuel Beckett. O silêncio possível. São Paulo: Ateliê Editorial, 2001, p. 186.

${ }^{19}$ Idem, p. 185-6.

20 É exatamente nesse momento que o autor conhece James Joyce. Tom MacGreevy, predecessor de Beckett no posto de Lecteur d'Anglais e um importante amigo do autor no período, foi o responsável pelas apresentações. Beckett estabeleceria a partir daí uma grande amizade tanto com Joyce como com sua família, passando a frequentar a casa do escritor em Paris. O convívio e admiração por Joyce fizeram com que Beckett adotasse hábitos de trabalho semelhantes, como a anotação de trechos de livros que pudessem servir de referência para trabalhos posteriores. Beckett ainda fazia parte do grupo de amigos que lia para Joyce quando este estava perdendo a visão e chegou a contribuir com pesquisas para o "Work in Progress" de Joyce na época, que viria a se transformar no Finnegans Wake. (Para mais detalhes em relação ao período, ver o quinto capítulo da biografia escrita por Knowlson, "The Paris Years", 1928-30, op. cit., p. 96-122)
} 
Arthur Rimbaud, Paul Éluard e Guillaume Apollinaire, o que the permitiu o trabalho intenso com a língua que o exercício da tradução proporciona ${ }^{21}$.

Ainda cabe lembrar que Beckett foi professor de literatura francesa no Trinity College, em Dublin, no começo dos anos 30 . No livro Beckett before Beckett. Samuel Beckett's Lectures on French Literature (2010), Brigitte Le Juez recupera, através do caderno de Rachel Burrows (a mais conhecida ex-aluna de Beckett), o curso dado pelo escritor ${ }^{22}$. É muito interessante observar, através das anotações da aluna, o que Beckett escolhe ensinar sobre Balzac, Stendhal, Gide, Proust, Dostoievski, Corneille e Racine. Le Juez procura no "professor Beckett" características que apareceriam em seu trabalho posterior. Ela destaca as críticas à literatura de Balzac e os elogios aos escritores que sabiam como retratar o mundo interior de seus personagens, algo que Beckett via em Proust e Dostoievski.

Segundo o caderno da aluna, Beckett destacava a qualidade do claro-escuro nos personagens do escritor russo, que deixava seus personagens parcialmente na sombra. Ele via Gide e Proust como sucessores de Dostoievski, pois estes sabiam preservar a complexidade do real, o inexplicável, e rejeitava os romances

\footnotetext{
${ }^{21}$ No artigo "Beyond the criterion of genre: Samuel Beckett's Ars Poetica" Mary Lydon defende que a prática da tradução foi fundamental para o desenvolvimento da arte poética de Beckett. Para Lydon, traduzir não só aperfeiçoou o francês do autor como permitiu que ele continuasse trabalhando com a língua francesa mesmo quando não estava produzindo seus próprios escritos. De fato, tanto o exercício de tradução dos poemas como o trabalho na École Normale de Paris devem ter fornecido o "terreno seguro" para que o autor investisse na mudança de idioma. (Lydon, Mary. Beyond the criterion of genre: Samuel Beckett's Ars Poetica. In: Engelberts, Matthijs (Ed.). Samuel Beckett Today/Aujourd'hui 8. Poetry and Other Prose/ Poésie et autres Proses. Amsterdam-Atlanta, GA: 1999)

22 Uma entrevista com Rachel Burrows a respeito das aulas de Beckett foi publicada em 1989. (Ver Gontarski, S.E., Fehsenfeld, Martha, and Mcmillan Dougald. Interview with Rachel Burrows, Dublin, Bloomsday, 1982. In: Journal of Beckett Studies, n. 11 e 12, 1989, p. 6-15).
} 
balzaquianos que, em sua visão, apenas descreviam a superfície deste real ${ }^{23}$.

É famosa a declaração em que Beckett compara o universo balzaquiano a um "mundo em clorofórmio": "Ler Balzac é receber a impressão de um mundo em clorofórmio. Ele é dono absoluto de seu material, pode fazer o que quiser com ele, pode prever e calcular sua menor vicissitude, pode escrever o fim de seu livro antes de ter acabado o primeiro parágrafo" ${ }^{24}$. A ideia de controle total sobre o mundo narrado está muito longe do que Beckett viria a defender a partir de seus escritos do pós-guerra. Há inclusive uma referência jocosa a Balzac no romance Murphy, exatamente no momento em que o narrador faz a descrição do quarto de Murphy e Celia:

\begin{abstract}
The room that Celia had found was in Brewery Road between Pentoville Prison and the Metropolitan Cattle Market. West Brompton knew them no more. The room was large and the few articles of furniture it contained were large. The bed, the gas cooker, the table and the solitary tallboy, all were very large indeed. Two massive upright unupholstered armchairs, similar to those killed under him by Balzac, made it just possible for them to take their meals seated ${ }^{25}$.
\end{abstract}

As predileções de Beckett são ainda ressaltadas no ensaio que ele escreveu sobre Proust (1931), no qual o autor volta a enfatizar a ligação deste com Dostoievski ao discorrer sobre o "impressionismo proustiano":

${ }^{23}$ Ver Le Juez, Brigitte. Beckett before Beckett. Samuel Beckett's lectures on French Literature. London: Souvenir Press, 2009, p. 28-9.

${ }^{24}$ Beckett, S. In: Disjecta. Miscellaneous Writing and a Dramatic Fragment. New York: Grove Press, 1984, p. 47 apud Berrettini, Celia. Samuel Beckett. Escritor Plural. São Paulo: Perspectiva, 2004, p. 33

${ }^{25}$ Beckett, S. Murphy. In: Samuel Beckett. The Grove Centenary Edition. Vol I. Novels. New York: Grove Press, 2006, p. 41. "O quarto que Celia achou ficava na Brewery Road, entre a prisão de Pentonville e o Mercado Metropolitano de Gado. West Brompton não veria mais sombra deles. Era um quarto grande e os poucos itens de mobília que comportava também eram grandes. A cama, o fogareiro a gás e o único armário eram todos muito grandes. Duas sólidas poltronas estofadas, parecidas com as que Balzac assassinava sob o próprio peso, permitiam que fizessem as refeições sentados". (Beckett, S. Murphy. Trad. Fábio de Souza Andrade. São Paulo: Cosac Naify, 2013, p. 52) 
Por impressionismo, refiro-me a seu relato não-lógico de certos fenômenos na ordem exata de sua percepção, antes que tenham sido distorcidos até a inteligibilidade, para que se adaptem a uma cadeia de causa e efeito [...]. Nesse contexto, é possível pensar na relação de Proust com Dostoievski, que expõe seus personagens sem explicálos. A isto poderia objetar-se que Proust não faz praticamente nada além de explicar seus personagens. Mas suas explicações são experimentais e não-demonstrativas. Ele os explica para que possam aparecer como realmente são - inexplicáveis. Ele os inexplica ${ }^{26}$.

Desde muito cedo, portanto, estavam delineadas tanto as preferências literárias como o domínio da língua e literatura francesas. O que Beckett elogiava em seus autores preferidos ia ao encontro de sua visão por uma literatura que assumisse sua própria incapacidade de fornecer um retrato seguro da realidade. A fluência e conforto que o autor sentia no idioma também serviram bem ao propósito que ele buscava - encontrar uma forma nova que se adequasse à virada narrativa pretendida, além de distanciar-se da tradição inglesa, principalmente a joyceana.

Em seu estudo sobre Beckett, Pascale Casanova questiona como fazer algo novo em literatura ou com a linguagem após Ulisses (1922)? Joyce era um ídolo e ao mesmo tempo uma sombra, alguém a ser superado ${ }^{27}$. O caminho encontrado por Beckett foi seguir a via oposta justamente a partir da adoção do francês. Casanova ainda comenta o périplo comum aos escritores irlandeses da época Dublin, Londres, Paris. Segundo a autora, se Yeats fundou em Dublin uma posição literária nacionalista e Shaw se converteu às exigências inglesas em Londres, Joyce teria concebido Paris como o novo reduto dos escritores irlandeses, excluindo tanto as demandas da poesia nacionalista como a submissão às regras literárias inglesas. Um

\footnotetext{
${ }^{26}$ Beckett, S. Proust. Trad. Arthur Nestrovski. São Paulo: Cosac Naify, 2003, p. 923.

27 No segundo capítulo de seu livro sobre o autor, Casanova discute os anos de formação de Beckett, detendo-se sobre a influência de Dante e, principalmente, de Joyce. Segundo Casanova, Beckett teve que lutar contra a influência de Joyce, autor que, ao mesmo tempo, abriu e fechou uma estrada, condenando aqueles que queriam segui-lo à mera imitação. (Ver Casanova, Pascale. Youth and Genesis. In: Samuel Beckett. Anatomy of a Literary Revolution. London: Verso Books, 2006).
} 
decreto de 1929 estabelecendo a censura aos livros que não se encaixassem ao padrão moral irlandês também determinou, para Beckett, o gradual adeus à Irlanda ${ }^{28}$.

Recentemente, uma série de obras sobre este "primeiro" Beckett tem sido publicada ${ }^{29}$. Com o foco nos cadernos do autor mantidos pelos arquivos responsáveis, alguns pesquisadores voltaram-se para as anotações e estudos pessoais do escritor no período de sua formação. Fazendo o mesmo movimento do livro de Le Juez, esses pesquisadores buscam conexões entre as anotações e a poética desenvolvida por Beckett. O livro de Matthew Feldman, Beckett's Books: A Cultural History of Samuel Beckett's Interwar Notes (2002), analisa os cadernos do escritor do começo dos anos 30 e mapeia todas as leituras realizadas por ele. Feldman ressalta o fato de Beckett ser um dos escritores mais eruditos do século XX. Além de literatura, as notas mostram estudos aprofundados em filosofia e psicologia.

Mais interessante do que ligar diretamente essas leituras às obras do autor, é refletir sobre a relação entre o acúmulo de conhecimento e a busca declarada pela ignorância. Essas notas antecipam a virada narrativa do pós-guerra, o início da segunda fase da prosa beckettiana. Feldman sugere que Beckett buscou conhecer bem o sistema que queria questionar e combater. No entanto, a simplificação da linguagem, o homem errante, as cidades hostis e a narração duvidosa também podem estar associados ao período histórico em que ele começou a escrever em primeira-pessoa, uma Europa destruída pós Segunda Guerra Mundial.

\footnotetext{
${ }^{28}$ Idem, p. 32-5. Sabemos também que os constantes conflitos de Beckett com a mãe foram decisivos para a mudança de país.

${ }^{29}$ Podemos citar como exemplo Samuel Beckett's Library (2013), de Dirk van Hulle e Mark Nixon, Samuel Beckett's German Diaries: 1936-1937 (2011), de Mark Nixon e Samuel Beckett's More Pricks than Kicks: In a Strait of Two Wills (2011), de John Pilling.
} 
A segunda fase, consequentemente, é profundamente marcada por essa mudança linguística empreendida pelo autor. Já morando em Paris no pós-guerra, por volta de 1945, Beckett escolhe o francês como língua literária justificando sua escolha como uma tentativa de "empobrecer" seus escritos, algo que considerava impossível de se atingir em inglês, sua língua materna, carregada de referências.

Apesar de nunca ter mudado de idioma, Virginia Woolf (18821941) expressa a mesma inquietude em relação à língua inglesa e uma espécie de "desconforto beckettiano" - a constatação de que as palavras sempre estarão aquém do que se deseja expressar:

... Words, English words, are full of echoes, of memories, of associations. They have been out and about, on people's lips, in their houses, in the streets, in the fields, for so many centuries. And that is one of the chief difficulties in writing them today - that they are stored with other meanings, with other memories, and they have contracted so many famous marriages in the past [...] Our business is to see what we can do with the old English Language as it is. How can we combine the old words in new orders so that they survive, so that they create beauty, so that they tell the truth? That is the question ${ }^{30}$.

A fala de Woolf é de 1937 e ecoa, de certo modo, algo que Beckett diz na famosa carta a Axel Kaun, curiosamente do mesmo ano: "Está se tornando mais e mais difícil, até sem sentido, para mim, escrever num inglês oficial. $E$, mais e mais, minha própria língua me parece como um véu que precisa ser rasgado para chegar às coisas (ou ao Nada) por trás dele" ${ }^{\prime 31}$.

\footnotetext{
30 "... As palavras, as palavras em inglês são cheias de ecos, de memórias, de associações. Elas estiveram por aí, nas bocas das pessoas, nas suas casas, nas ruas, nos campos, por tantos séculos. E essa é uma das principais dificuldades em escrevê-las hoje - pois elas estão guardadas com outros significados, com outras memórias, e elas contraíram tantos casamentos famosos no passado [...] Nosso trabalho é ver o que podemos fazer com a velha língua inglesa como ela é. Como podemos combinar as velhas palavras em novos arranjos para que elas possam sobreviver, para que elas possam criar beleza, para que elas possam dizer a verdade? Essa é a questão". (Woolf, Virginia. Craftsmanship. In: The Death of the Moth and other essays. Orlando, Florida: Harcourt Brace \& Company, 1942)

${ }^{31}$ Beckett, S. Carta a Axel Kaun. In: Andrade, Fábio de Souza. Samuel Beckett. O silêncio possível. São Paulo: Ateliê Editorial, 2001, p. 169
} 
O incômodo de Woolf e Beckett está ligado aos questionamentos dos escritores, principalmente a partir do Modernismo, em torno das formas de representação literária. Em Mr. Bennett e Mrs. Brown, palestra de 1924, Virginia Woolf pedia paciência aos leitores de sua época: "Tolerate the spasmodic, the obscure, the fragmentary, the failure. Your help is invoked in a good cause" $^{\prime 32}$. A autora de Mrs. Dalloway discorre sobre uma transição necessária nas formas de narrar e estabelece o ano de 1910 como marco de uma grande mudança nas relações humanas e no próprio caráter humano, que se refletiria na literatura ${ }^{33}$. Segundo Woolf, as velhas ferramentas literárias não serviam mais à sua geração e as novas estavam sob intensa experimentação. Como escritora, ela procura analisar e se posicionar em um debate literário de seu tempo, terminando sua fala com uma aposta otimista.

Cronologicamente anterior à ruptura estética que Beckett apresentaria com sua trilogia romanesca, Woolf já aponta o ambiente modernista de experimentação das formas. Beckett decidiu adotar uma postura extrema diante deste desconforto com a palavra, rompendo com o idioma materno a partir da segunda fase de sua prosa. São deste período as novelas "L'expulsé", "Le calmant", "La fin" (1955) e "Premier Amour" (1970), a trilogia já mencionada e os fragmentos Textes pour rien (1955).

Indissociável da opção pela língua francesa está o emprego do narrador em primeira-pessoa, emblemático de toda essa fase. 0 leitor das novelas e da trilogia reconhece de imediato o homem

\footnotetext{
32 "Tolerem o espasmódico, o obscuro, o fragmentário, a falha. Sua ajuda é invocada por uma boa causa". (Woolf, Virginia. Mr. Bennett and Mrs. Brown. London: Hogarth Press, 1924)

${ }^{33}$ Em um ensaio sobre Mrs. Dalloway, Ann Banfield também lembra que 1910 foi o ano de uma exposição que divulgara os pintores pós-impressionistas na Inglaterra. Segundo Banfield "Para dar nova forma ao romance, a escritora tomou como modelo as artes visuais, visto que o modernismo, segundo sua intuição, foi de início um movimento pictórico" (Banfield, Ann. Mrs. Dalloway. In Moretti, Franco. $A$ cultura do romance. Vol. I. Trad. Denise Bottmann. São Paulo: Cosac Naify, 2009, p. 961).
} 
errante e solitário que narra sua própria história de maneira bastante peculiar e perturbada. Essas novelas abordam a peregrinação do narrador-protagonista pelas ruas de uma cidade indefinida, na qual ele se põe em movimento contra sua vontade, em busca de abrigo e isolamento social, sempre em virtude da expulsão de seu local de origem. Ele vaga pelas ruas enquanto conta sua história. O questionamento sobre o material narrado, as falhas de memória, as dúvidas e o impasse como condutor narrativo são algumas das características deste narrador. Alguns trechos da novela "Premier Amour" são um bom exemplo do estilo de narração aqui descrito ${ }^{34}$ :

$\mathrm{J}^{\prime}$ associe, à tort ou à raison, mon mariage avec la mort de mon père, dans le temps. Qu'il existe d'autres liens, sur d'autres plans, entre ceux deus affaires, c'est possible. Il m'est déjà difficile de dire ce que je crois savoir. ${ }^{35}$

Je me demande si tout cela n'est pas de l'invention, si en realité les choses ne se passèrent pas tout autrement, selon un schéma qu'il m'a fallu oublier. Et cependant son image à elle reste liée à celle du banc, pour moi, non pas du banc de la nuit, mais du banc du soir, de sorte que parler du banc, tel qu'il m'apparaissait le soir, c'est parler d'elle, pour moi. Cela ne prouve rien, mais je ne veux rien prouver ${ }^{36}$.

Mais quelques semaines plus tard, plus mort que vif, je retournai encore au banc, cela faisait la quatrième ou cinquième fois depuis que je l'avais abandonné, à la même heure à peu près sous le même ciel, non, ce n'est pas cela non plus, car c'est toujours le même ciel et

\footnotetext{
${ }^{34}$ A novela trata da relação entre o protagonista que, expulso da casa em que morava, passa a vagar pelas ruas e a prostituta Lulu, que ele conhece em um banco da cidade.

${ }^{35}$ Beckett, S. "Premier Amour". Paris : Les Éditions de Minuit, 1970, p. 7. "Associo, com ou sem razão, o meu casamento à morte de meu pai, em outros tempos. Talvez existam outras ligações, em outros planos, entre esses dois acontecimentos, é possível. Já me é difícil dizer o que julgo saber" (Beckett, S. Primeiro Amor. Trad. Célia Euvaldo. São Paulo: Cosacnaify, 2004, p. 1-2)

${ }^{36}$ Idem, p. 22. "Às vezes me pergunto se tudo isso não é invenção, se na realidade as coisas não se passaram de modo completamente diverso, segundo um esquema que precisei esquecer. No entanto a imagem dela permanece ligada à do banco, para mim, não o banco da noite, mas o banco do anoitecer, de modo que falar do banco, tal como eu o via ao anoitecer, é falar dela, para mim. Isso não prova nada, mas não quero provar nada". (Idem, p. 12)
} 
c'est ne jamais le même ciel, comment exprimer cette chose, je ne I'exprimerai pas, voilà. ${ }^{37}$.

O questionamento em torno do "como dizer", como expressar em palavras, não aparece apenas nas novelas, mas também nos romances da trilogia e nos Textes pour rien, obras nas quais a forma de expressão é tão questionada quanto o próprio valor e necessidade da narração.

Após vagar pela cidade, o narrador de "L'expulsé" conclui sua história dizendo: "Je ne sais pas pourquoi j'ai raconté cette histoire. J'aurais pu tout aussi bien en raconter une autre. Peut-être qu'une autre fois je pourrai en raconter une autre. Ames vives, vous verrez que cela se ressemble" ${ }^{38}$. Entretanto, apesar do aparente descaso, esse narrador errante em primeira-pessoa protagoniza outras três histórias e nele está a própria gestação dos personagens Molloy, Malone e do eu de L'innommable. Molloy inicia sua narração dessa forma:

\begin{abstract}
Je suis dans la chambre de ma mère. C'est moi qui y vis maintenant. Je ne sais pas comment j'y suis arrivé. Dans une ambulance peutêtre, un véhicule quelconque certainement. On m'a aidé. Seul je ne serais pas arrivé. Cet homme qui vient chaque semaine, c'est grace à lui peut-être que je suis ici. Il dit que non. Il me donne un peu d'argent et enlève les feuilles. Tant de feuilles, tant d'argent. Oui, je travaille maintenant, un peu comme autrefois, seulement je ne sais plus travailler ${ }^{39}$.
\end{abstract}

\footnotetext{
37 Idem, p. 36. "Mas algumas semanas depois, mais morto do que vivo, voltei novamente ao banco, era a quarta ou quinta vez desde que eu a tinha abandonado, à mesma hora mais ou menos, isto é, mais ou menos sob o mesmo céu, não, também não é isso, pois é sempre o mesmo céu e nunca é o mesmo céu, como expressá-lo em palavras, não o expressarei, pronto. (Idem, p. 20).

38 Beckett, S. Nouvelles et Textes pour rien. Paris : Les Éditions de Minuit, 1958, p.37. "Não sei por que contei essa história. Poderia muito bem ter contado outra.Talvez outra hora poderei contar outra. Almas vivas, verão que elas se parecem". (Beckett, S. O expulso. In: Novelas. Trad. Eloísa Araújo Ribeiro. São Paulo: Martins Fontes, 2006, p. 24).

${ }^{39}$ Beckett, S. Molloy. Paris : Les Éditions de Minuit, 1982. P. 7. "Estou no quarto de minha mãe. Sou eu que moro lá agora. Não sei como cheguei lá. Numa ambulância talvez, num veículo qualquer certamente. Me ajudaram. Sozinho não teria chegado. Esse homem que vem toda semana, é graças a ele que estou aqui. Ele diz que não. Me dá dinheiro e leva as folhas. Tantas folhas, tanto dinheiro. Sim, trabalho agora,
} 
Molloy começa sua jornada no quarto de sua mãe, em meio a folhas que deve escrever e entregar sem saber muito bem por que. Ainda assim, ele cumpre a tarefa. O romance abre-se com uma alusão ao ofício da escrita. No entanto, o que Molloy enfatiza neste trecho é sua dúvida, tanto em relação à sua condição atual ("não sei como cheguei lá") como em relação à sua atividade ou profissão ("Esse homem que vem toda semana [...] Tantas folhas, tanto dinheiro"). A incerteza será uma marca de sua narração.

A principal atividade de Malone também é a escrita. Entretanto, se Molloy escreve por obrigação, Malone o faz para passar o tempo e ter companhia enquanto aguarda seu fim. Mais uma vez aqui, temos a presença dessa ambiguidade entre a insatisfação com o que se narra e a necessidade de narrar, temática que se inicia com as novelas. A peregrinação de Molloy pelas ruas é bastante parecida com a do protagonista anônimo de "L'expulsé", mostrando que muitas situações presentes nas novelas foram posteriormente desenvolvidas na trilogia romanesca. Além da errância, o protagonista que narra de uma condição entre a vida e a morte, presente em Malone Meurt, também aparece em "Le calmant".

Na segunda parte de Molloy, o personagem Moran, após retornar de sua caçada frustrada a Molloy, termina o romance escrevendo um relatório a pedido de uma "voz" que diz ouvir. A narração de Moran modifica-se no decorrer de seu relato. $O$ que a princípio era claro começa a confundir-se e ele passa a assumir características de Molloy, o que sugere uma fusão entre os dois personagens. Além disso, o romance acaba por pregar uma peça no leitor, já que o final da história nos remete ao começo do relato de Moran, frustrando a expectativa de que a história de Molloy se 
esclareça ou de que Moran o encontre e a esclareça para nós. Propositadamente, não se chega a nenhum lugar com a narrativa. Podemos ler a peregrinação dos dois personagens (ou o duplo de um mesmo) como uma busca pela própria forma da narrativa ou ainda uma crítica aos moldes tradicionais do gênero romanesco, uma tentativa de encontrar uma saída para o impasse da escrita.

Assim como nas novelas, Molloy e Moran vagam por suas cidades ou regiões. Lembremos que o "vagar pelas ruas" é destaque em romances canônicos. É só pensarmos nas andanças de Frédéric Moreau por Paris em L'éducation sentimentale (1869), nos personagens de Mrs Dalloway (1925) caminhando por Londres ou ainda de Stephen Dedalus e Leopold Bloom percorrendo a Dublin de Ulisses $^{40}$. No entanto, ao contrário dos heróis que se locomovem livremente pelas ruas e do próprio papel de destaque que a cidade exerce nesses romances, o percurso de Molloy é marcado pela dificuldade e aponta para uma paralisia. De acordo com Fábio de Souza Andrade:

\begin{abstract}
Como metáfora da narrativa, o espaço de Molloy vale pela descrição do método do romance: movimentar-se de forma tortuosa para tentar seguir em frente, vencer o beco sem saída do romance moderno não mais pela narrativa linear, mas por um narrar que aparentemente descreve círculos, gira em falso. A dificuldade física do movimento de Molloy, cada vez maior, chegando ao extremo do movimento à força dos pulsos, quando ambas as pernas falham, espelha a dificuldade da narrativa ${ }^{41}$.
\end{abstract}

A própria descrição da "região de Molloy" não traz nenhum traço que permita a identificação com uma cidade específica, mantendo-se indefinida, dentro do universo próprio e instável do romance, além de ser um desses momentos nos quais o humor beckettiano aflora:

\footnotetext{
${ }^{40}$ Romances de Gustave Flaubert, Virginia Woolf e James Joyce, respectivamente.

${ }^{41}$ Andrade, Fábio de Souza, op. cit., p. 61.
} 
Ce bourg, ou ce village, disons-le tout de suite, s'appelait Bally, et représentait, avec les terres en dependant, une superficie de cinque ou six milles carrés tout au plus. Dans les pays évolués on appelle ça une commune, je crois, ou un canton, je ne sais pas, mais chez nous il n'existe pas de terme abstrait et générique pour ces subdivisions du territoire. Et pour les exprimer nous avons un autre système, d'une beauté et simplicité remarquables, et qui consiste à dire Bally (puisqu'il s'agit de Bally) lorsqu'on veut dire Bally et Ballyba lorsqu'on veut dire Bally plus les terres y afferents et Ballybaba lorsqu'on veut dire les terres de Bally exclusives de Bally lui-même. Moi par exemple je vivais, et à bien y réflechir vis toujours, à Shit, chef-lieu de Shitba. Et le soir, quand je me promenais, histoire de prendre le frais, en dehors de Shit, c'est le frais de Shitbaba que je prenais, et nul autre $^{42}$.

Nesta trilogia, o tema da escrita e de seus impasses ganha ainda mais força do que nas novelas. Os protagonistas dos dois primeiros romances estão às voltas com o ato de narrar sua própria história de vida, concentrando o discurso em suas mãos. Esse foco se modifica na fase final da prosa do autor. Outra diferença marcante está em uma espécie de "descarnamento" ou desintegração das narrativas, processo que se inicia justamente com o último romance desta trilogia, $L^{\prime}$ innommable ${ }^{43}$. Nessa obra os questionamentos vão muito além do "como narrar" e passam a se dirigir também a "quem está narrando" ou "por que está narrando".

42 Beckett, S. Molloy, op. cit., p. 181-2. "Esta cidade-mercado, ou esta aldeia, digase de imediato, chamava-se Bally, e representava, com as terras adjacentes, uma superfície de cinco ou seis milhas quadradas no máximo. Nos países desenvolvidos chamam a isso comuna, acho, ou cantão, não sei, mas entre nós não existem termos abstratos e genéricos para essas subdivisões de território. E para expressálas temos outro sistema, de beleza e simplicidade notáveis, e que consiste em dizer Bally (já que se trata de Bally) quando você quer dizer Bally e Ballyba quando você quer dizer Bally mais as terras que Ihe cabem e Ballybaba quando você quer dizer as terras de Bally exclusivas da própria Bally. Eu por exemplo morava, e pensando bem ainda moro, em Shit, sede de Shitba. E à noitinha, quando passeava, para tomar a fresca, ao redor de Shit, era a fresca de Shitbaba que eu tomava, e nenhuma outra" (Beckett, S. Molloy, op, cit., p. 184)

${ }^{43} \mathrm{~A}$ trajetória do narrador em primeira-pessoa beckettiano e a angústia relacionada à incapacidade de narrar foram temas da minha dissertação de mestrado, especialmente no que se refere às novelas e aos Textes pour rien. O título do trabalho é Um narrador no limite: O caminho da primeira-pessoa beckettiana das nouvelles aos Textes pour rien. São Paulo: FFLCH/USP, 2009. 
L'innommable pode até mesmo ser lido como um desabafo do escritor em sua busca pelo silêncio, pondo em xeque o próprio estatuto de ficção da obra. Quem lê o livro é tragado por um mundo de questionamentos que vão muito além dos fragmentos de narrativa ali presentes. É como se acompanhássemos o próprio processo de criação e pensamento do autor: "Où maintenant? Quand maintenant? Qui maintenant? Sans me le demander. Dire je. Sans le penser. Appeler ça des questions, des hypothèses. Aller de l'avant, appeler ça aller, appeler ça de l'avant" ${ }^{\prime 4}$. O que observamos nessas primeiras frases do romance é a própria tentativa de criá-lo, o esforço em seguir adiante.

Em seu conhecido texto sobre a trilogia de Beckett, "Où maintenant? Qui maintenaint?" Maurice Blanchot retoma justamente essa abertura do romance para destacar o fato do narrador de L'innommable não conseguir formar "um rosto", uma identidade: "O que era narrativa tornou-se luta, o que tomava algum aspecto, mesmo que fosse o de seres em farrapos e em pedaços, é agora sem rosto. Quem fala aqui?"45.

Blanchot vê L'innommable como uma obra que se aproxima do próprio movimento originário do qual vêm todos os livros - seria esse o lugar ocupado pelo eu que narra, assombrado pelas suas criações passadas. De fato, essa é justamente a obra em que há um acirramento das questões em torno da voz narrativa (quem fala?) aliado à própria desintegração da mesma:

Celui qui parle, il a dû voyager, il a dû voir, quelques hommes, quelques choses, il a dû être là-haut, sous la lumière, ou bien on lui a raconté des histoires, des voyageurs I'ont trouvé, ça m'innocente,

\footnotetext{
${ }^{44}$ Beckett, S. L'innommable. Paris: Les Éditions de Minuit, 2004, p. 7. "Onde agora? Quando agora? Quem agora? Sem me perguntar. Dizer eu. Sem pensar. Chamar isso de perguntas, hipóteses. Ir adiante, chamar isso de ir, chamar isso de adiante" (Beckett, S. O inominável. Trad Ana Helena Souza. São Paulo: Globo, 2009, p. 29) ${ }^{4}$ Blanchot, Maurice. Onde agora? Quem agora? In: O livro por vir. Trad. Leyla Perrone- Moisés. São Paulo: Martins Fontes, 2005, p. 311-2.
} 
qui dit, ça m'innocente, lui, c'est lui qui le dit, ou c'est eux qui le disent, oui, eux, c'est eux qui raisonnent, eux qui croient, non, un seul, celui qui a vécu, ou qui a vu des ayant vécu, c'est lui qui parle de moi, comme si j'étais lui, comme si je n'étais pas lui, les deux, e comme si j'étais d'autres, I'un après l'autre, c'est lui l'affligé, moi, je suis loin, vous entendez, [...] alors il dit je, comme si j'étais lui, ou dans une autre, alors il dit Murphy, ou Molloy, je ne sais plus, comme si j'étais Malone... ${ }^{46}$

\section{Investigando a tendência autobiográfica do romance contemporâneo, Adriano Schwartz cita a trilogia beckettiana como um possível marco para uma nova configuração da forma romanesca} após a Segunda Guerra Mundial:

É como se houvesse uma necessidade fundamental de retornar à cena em que tudo implodiu. Não por acaso outro momento de corte possível para marcar essa nova configuração do romance é a publicação da trilogia Molloy, Malone Morre e O inominável, de Samuel Beckett, entre 1946 e 1953. O último, por exemplo, começa cheio de dúvidas ("Onde agora? Quando agora? Quem agora? Sem me perguntar. Dizer eu. Sem pensar. Chamar isso de perguntas, hipóteses...") e termina de modo não menos enigmático ("... é preciso continuar, não posso continuar, vou continuar"). Entre um trecho e outro, o romance dinamita quase todas as convenções do romance: não há personagens, enredo, progressão temporal, ambiente, representação; apenas uma voz que fala, fala e fala, sabe-se lá de onde, sem nenhuma motivação. Ali, a experiência modernista é levada ao extremo, a uma espécie de marco regulatório final, a partir do qual seria preciso retroceder se se quisesse continuar. Se o homem encolhera, se a humanidade atingira o fundo do poço, talvez esse retorno, esse recomeço, passasse por um olhar ficcionalizado para a própria história pessoal, para a constituição contraditória e incerta desse único sujeito que

\footnotetext{
${ }^{46}$ Beckett, S. L'innommable. Paris: Les Éditions de Minuit, 2004, p. 194-5. "Aquele que fala, deve ter viajado, deve ter visto, alguns homens, algumas coisas, deve ter estado lá em cima, sob a luz, ou então Ihe contaram histórias, viajantes o encontraram, isso me inocenta, quem diz, isso me inocenta, ele, é ele quem diz ou são eles que dizem, sim, eles, são eles que raciocinam eles que acreditam, não, um só, aquele que viveu, ou que viu os que viveram, é ele que fala de mim, como se eu fosse ele, como se eu não fosse ele, os dois, e como se eu fosse outros, um após outro, é ele o aflito, eu, eu estou longe, vocês estão ouvindo [...] então diz Murphy, ou Molloy, não sei mais, como se eu fosse Malone..." (Beckett, S. O inominável. Trad. Ana Helena Souza. São Paulo: Globo, 2009, p. 171)
} 
talvez se possa conhecer e desconhecer minimamente, o pequeno $\mathrm{eu}^{47}$.

A motivação do eu de L'innommable parece ser justamente buscar algum centro, algo em que se apoiar, o que ele não encontra, uma vez que sua própria fala parece vir de outro lugar. A voz que vem "sabe-se lá de onde" começa a atormentar o narrador e se desenvolverá na ficção final de Beckett, assumindo uma nova configuração.

A posição do narrador de L'innommable é frágil e apesar de fazer referências aos protagonistas de obras anteriores e nos remeter a essas histórias, seu momento é de retração, de investigação sobre sua própria origem. Há, pela primeira vez aqui, um recuo para a interioridade que será a marca de alguns textos da fase final, também focados na abordagem de como se inicia uma criação. No entanto, ao contrário da ficção final, L'innommable está na ponta de uma linha que o liga à exploração da primeira-pessoa narrativa iniciada com as novelas. A obra mais parece representar o fim de um processo do que o começo.

Em L'innommable, as tentativas de narrar arruínam-se por completo, seu espaço é cinzento e sua situação, crítica ao extremo ele não sabe quem é, quem fala, onde está e por que está ali. É claro que, na medida do possível, também vai tentar narrar histórias, criando suas ficções em torno dos personagens Mahood e Worm, mas o que predomina na obra, especialmente da metade para o final são os questionamentos. Aqui, a consciência criativa é intensamente inquirida. A obra ocupa um papel de grande destaque na prosa de Beckett e a partir dela podemos puxar o fio desenvolvido posteriormente em uma obra como Company. Nesta última, a voz a quem o narrador de L'innommable atribui seu discurso, ganha corpo

\footnotetext{
47 Schwartz, Adriano. A tendência autobiográfica do romance contemporâneo. Coetzee, Roth e Piglia. In: Novos Estudos Cebrap, n. 95, março 2013.
} 
e dicção própria transformando-se em um narrador. Essa voz começa

a assumir diversos tratamentos na obra do autor, não apenas na prosa, mas também em seu drama ${ }^{48}$.

Se nos romances da trilogia ainda é possível acompanhar a trajetória de um herói romanesco - ainda que às avessas, "aos trapos" e em meio a uma série de confrontos com a linguagem e o ato de narrar - os textos em prosa da fase final são de difícil leitura e definição. Não possuem um centro claro. Transmitem esse próprio vagar da mente que busca. Ela procura por uma história, um narrador, um personagem, uma imagem que possa apreender, ao mesmo tempo em que questiona suas intenções e seu próprio método.

Em seus últimos textos, surge ainda um novo tipo de narrador, mais preocupado em investigar o que se observa. É como se diante da angústia derivada principalmente de obras como L'innommable ou os Textes pour rien, o autor escolhesse tomar distância de seu material, partindo para um novo ângulo de observação. Neste momento, não só a capacidade de representação é posta em xeque, mas também os próprios sentidos da percepção humana, principalmente o "ver" e o "ouvir", verbos aos quais poderíamos associar duas obras da fase final: IIl Seen IIl Said, pela importância dada ao olho e Company, que tem como protagonista um ouvinte ${ }^{49}$.

No prefácio à publicação brasileira de $\mathrm{O}$ despovoador e Mal Visto Mal Dito, Fábio de Souza Andrade comenta essa etapa:

\footnotetext{
${ }^{48}$ A questão da voz na obra de Beckett será analisada na terceira parte deste trabalho.

${ }^{49} \mathrm{O}$ escritor Charles Juliet, grande admirador de Beckett, relata que ao falar sobre o processo de envelhecimento, o autor costumava destacar a superioridade da audição em relação à visão. (Juliet, Charles. Conversations with Samuel Beckett and Bram van Velde. Netherlands: Academic Press Leiden, 1995, p. 147 e 152). O tema rendeu diversos trabalhos pois, além de Company, muitas peças da fase final giram em torno de um ouvinte, entre as quais Ohio Improptu, $A$ piece of monologue, That Time e Rockaby.
} 
Ver e ouvir, mediações necessárias da criação, são a matéria primeira da ficção final beckettiana, transfigurando o eu em olho devorador, quando o I se faz eye. [...]

Nos rastros desses textos ficcionais, autor e leitor percorrem tentativas de explorar um labirinto muito peculiar, o "manicômio do crânio", consciência profunda ou abismos de inconsciência, onde vontade expressiva e vestígios do mundo se combinam em corredores de linguagem mais ou menos triunfante, mais ou menos arruinada. Renunciar à ilusão do controle - fio de Ariadne com o qual acenava, sereno, o narrador clássico - e examinar as condições dessa falência (moderna, por certo, e mediada pela onipresença de um olhar investigativo cioso de si, observador e observado) é para onde aponta a narrativa beckettiana madura, a da "última pessoa narrativa", trabalho das três últimas décadas de sua vida ${ }^{50}$.

A chamada terceira fase abarcaria, assim, os últimos textos escritos pelo autor, marcados por um retorno ao uso da língua inglesa na composição da maior parte das obras e, principalmente, por uma segunda virada narrativa. O narrador em primeira-pessoa explorado ao seu limite na fase anterior não aparece mais nesta etapa e Beckett começa a utilizar um narrador observador, uma "nova terceirapessoa", instância que tenta descrever objetivamente as cenas que vê ou imagina, frustrando-se frequentemente. É o que ocorre em textos como IIl Seen IIl Said ou Worstward $\mathrm{Ho}^{51}$. Neste momento final, temas como os bastidores da criação artística e o trabalho da imaginação na mente passam a ocupar o centro das obras.

Os textos mais significativos dessa etapa são os que formam a chamada "segunda trilogia" beckettiana - Company, Ill Seen Ill Said e Worstward Ho. Vale ressaltar que Beckett não gostava da ideia de que esses três textos fossem publicados como uma unidade, na forma de uma trilogia. As primeiras edições, tanto a americana (Grove Press) como a inglesa (Calder), saíram com o título de Three Novels, seguido pelo nome das três obras. No entanto, com o passar

\footnotetext{
${ }^{50}$ Andrade, Fábio de Souza. Prefácio. Try again. Fail again. Fail better. In: Beckett, S. O despovoador/Mal Visto Mal Dito. Trad. Eloísa Araújo Ribeiro. São Paulo: Martins Fontes, 2008, p. xi-xii.

${ }^{51}$ As duas obras são bem distintas. Estou apenas apontando um expediente comum a ambas - o esforço do narrador no sentido de descrever o que vê.
} 
do tempo, a crítica passou a se referir aos três textos como "segunda trilogia", especificação que acabou se tornando convenção ${ }^{52}$. Mas há também neste período obras como Le dépeupleur (1971) ou textos curtos como All Strange Away (1976) marcando uma outra vertente desta fase - a dos textos centrados no confinamento de personagens, na descrição de espaços fechados. Em Le dépeupleur, por exemplo, o narrador nos fala sobre as regras que regem a vida de um grupo de pessoas confinadas em um cilindro, seus hábitos, suas funções nesse universo ${ }^{53}$ :

Un corps par mètre carré soit un total de deux cents corps chiffre rond. Parents proches et lointains ou amis plus ou moins beaucoup en principe se connaissent. L'identification est rendue difficile par la presse et par l'obscurité. Vus sous un certain angle ces corps sont de quatre sortes. Premièrement ceux qui circulent sans arrêt. Deuxièmement ceux qui s'arrêtent quelquefois. Troisièmement ceux qui à moins d'en être chassés ne quittent jamais la place qu'ils ont conquise et chassés se jettent sur la première de libre por s'y immobiliser de nouveau. Cela n'est pas tout à fait exact. Car si chez ces derniers ou sédentaires le besoin de grimper est mort il n'en est pas moins sujet à d'étranges résurrections. [...] Voilà en gros pour ces corps vus sous un premier angle et pour cette notion et ses suítes si elle est maintenue ${ }^{54}$.

\footnotetext{
${ }^{52}$ Ver sobre o assunto Gontarski, S.E. The conjuring of something out of nothing: Samuel Beckett's "closed spaces" novels. In: Beckett, S. Nohow on. Company, III seen IIl said, Worstward Ho. Three novels by Samuel Beckett with an Introduction of S.E. Gontarski. New York: Grove Press, 1996.

${ }^{53}$ Essa obra é comumente associada ao inferno dantesco. Além de Joyce, Dante e Proust também foram grandes referências para Beckett. Basta mencionar o primeiro conto de More Pricks than Kicks, "Dante and the lobster" e o já mencionado ensaio Proust, escrito quando Beckett tinha apenas 22 anos.

${ }^{54}$ Beckett, S. Le dépeupleur. Paris: Les Éditions de Minuit, 1970, p. 12-3 e 14. "Um corpo por metro quadrado ou seja um total de duzentos corpos número redondo. Parentes próximos e distantes ou amigos mais ou menos muitos em princípio se conhecem. A identificação torna-se difícil pela aglomeração e pela obscuridade. Vistos de um certo ângulo esses corpos são de quatro tipos. Em primeiro lugar aqueles que circulam sem parar. Em segundo aqueles que às vezes param. Em terceiro aqueles que a menos que sejam expulsos nunca deixam o lugar que conquistaram e expulsos se jogam sobre o primeiro livre para ali se imobilizar de novo. Não é exatamente assim. Pois se nestes últimos ou sedentários a vontade de escalar morreu ela não deixa de estar sujeita a estranhas ressurreições.[...] Eis grosso modo esses corpos vistos de um primeiro ângulo e essa noção e suas consequências se ela for mantida" (Beckett, S. O despovoador. Mal visto mal dito. Trad. Eloisa Araújo Ribeiro. São Paulo: Martins Fontes, 2008, p. 8 e 10)
} 
O tom mais neutro, de observação distanciada, como no trecho acima, é marca dessa obra e também uma característica dos textos da fase final, conforme já apontado. O narrador de Le dépeupleur parece não se afetar com o que vê, tendo como objetivo uma espécie de descrição pura e imparcial. Ainda assim, a dúvida e a hesitação, marcas da prosa de Beckett, se fazem presentes através de alguns comentários dispersos pela obra. No trecho citado, após a descrição dos tipos de corpos temos a frase "Não é exatamente assim" ou "se ela for mantida". A narração detalhada tem momentos de recuo que sugerem possibilidades não aventadas pelo narrador, ou seja, seu controle não é total.

Guardadas as devidas especificidades podemos fazer uma associação entre o confinamento no cilindro e a retração para o interior da mente que ocorre nos textos da segunda trilogia. São duas configurações para uma mesma temática, a do aprisionamento, seja no espaço, seja na mente. É este o caminho que os personagens beckettianos seguem se tomarmos como referência a imobilidade que começa a acometer os protagonistas da trilogia do pós-guerra. Essa trajetória também se dá nas peças do autor, nas quais observamos uma perda cada vez maior da mobilidade dos personagens até chegarmos ao próprio limite ou ao que restou de um corpo - uma boca (Not I), uma cabeça (Play, That Time).

Beckett fez uso da narração em terceira pessoa, onisciente, nas obras da primeira fase. No entanto, ainda que mais próxima de um molde tradicional de narrativa, essa primeira voz beckettiana já se intrometia e comentava as ações de sua história, expediente bastante recorrente na prosa do autor, como veremos logo a seguir. A denominação de "nova terceira-pessoa" na prosa final está sendo usada para marcar essa diferença em relação às primeiras obras. 


\subsection{A crítica e as fases}

Diversos estudiosos da obra de Beckett detiveram-se na periodização de sua prosa. Primeiramente vamos citar Carla Locatelli que, ao analisar a produção do cômico na prosa beckettiana, comenta estas três etapas.

Para Locatelli, na primeira fase - que ela chama de "paródica" Beckett utiliza elementos da tradição literária com a intenção de criticar e transpor essa estrutura. Seria uma fase intertextual, da qual fariam parte obras como More pricks than Kicks e Murphy. Aqui, o autor refere-se ao cânone para parodiá-lo. É o caso da referência a Dante no primeiro conto de More Pricks than Kicks - "Dante and the lobster"155. A segunda fase, chamada por ela de "metanarrativa", concentraria-se na paródia dos próprios gêneros literários utilizados. Esta fase, intratextual, deixaria claro que estamos na presença da literatura devido às interrupções narrativas de caráter metalinguístico. A autora cita como exemplo as obras dos anos 40 e 50, período em que estão as novelas e a trilogia do pós-guerra. A última fase, definida como "essencialmente discursiva" seria a mais problemática e o humor ocorreria no nível do discurso. Neste momento estaria a prosa final de Beckett na qual o próprio estatuto da linguagem é posto em xeque ${ }^{56}$.

No ensaio "O esgotado", Gilles Deleuze também faz uma análise da obra de Beckett propondo uma divisão da mesma em três línguas - língua dos nomes, língua das vozes e língua das imagens. Aqui não há separação entre a prosa e outros trabalhos do autor. Apesar de o ensaio ter como objetivo a análise de quatro peças televisivas de

\footnotetext{
${ }^{55}$ Neste conto, após desistir de entender um trecho da Divina Comédia, Belacqua concentra-se em três afazeres: preparar seu almoço, comprar uma lagosta para sua tia e ir à aula de italiano.

56 Locatelli, Carla. Comic strategies in Beckett's narratives. In : Unwording the world. Samuel Beckett's prose works after the Nobel Prize. Philadelphia: University of Pennsylvania Press, 1990.
} 
Beckett - Quad(1984), Ghost Trio(1976), ...but the clouds...(1977) e Nacht und Traüme(1984) - a obra beckettiana como um todo é vista como uma busca pelo que Deleuze chama de "esgotamento do possível": "Há, pois quatro maneiras de esgotar o possível: formar séries exaustivas de coisas, estancar os fluxos de voz, extenuar as potencialidades do espaço, dissipar a potência da imagem" ${ }^{\prime 57}$. Desde os cálculos combinatórios feitos por Murphy para comer suas bolachas no parque, passando pela cena de Molloy com suas pedras de chupar, até a tentativa de despotencializar o quadrado em Quad, para Deleuze, a busca de Beckett estaria em função dessa dissipação total - dos nomes, dos objetos, das vozes, dos espaços e das imagens. Seguindo uma linha similar, no ensaio "Towards the zero of language", Martin Esslin também chama a atenção para o "esforço de concisão da imagem" sempre buscado por Beckett. Para Esslin, o tal zero da linguagem teria sido atingido justamente nessas quatro peças televisivas que, para ele, formariam um novo gênero - "poemas sem palavras, poesia visual" ${ }^{\prime 58}$.

No texto já mencionado anteriormente, Stanley Gontarski também comenta uma mudança fundamental na prosa de Beckett, relacionada à passagem da segunda para a terceira fase. Seria a troca dos espaços abertos e de errância familiares aos personagens das novelas e da trilogia aos espaços de confinamento presentes nas narrativas finais. Essa mudança exigiu que o autor criasse um novo estilo para narrar uma nova condição. Neste ponto está a substituição da narração em primeira- pessoa pelo que anteriormente chamamos de uma "nova terceira-pessoa". Gontarski inclusive aponta o momento em que isso ocorre na obra beckettiana, quando ela se encaminha para a prosa final, citando uma passagem de "All strange

\footnotetext{
${ }^{57}$ Deleuze, Gilles. O esgotado. In: Sobre o teatro: Um manifesto de menos; $O$ esgotado. Trad. Fátima Saadi, Ovídio de Abreu, Roberto Machado. Rio de Janeiro: Jorge Zahar, 2010, p. 86.

${ }^{58}$ Esslin, Martin. Towards the zero of language. In: Acheson, James \& Arthur, Kateryna (Ed.). Beckett's Later Fiction and Drama. Texts for Company. London: The Macmillan Press, 1987.
} 
away" (1976): "Out of the door and down the road in the old hat and coat like after the war, no, not that again. Five foot square, six high, no way in, none out, try for him there ${ }^{\prime \prime 59}$.

Com as devidas variações de opinião e enfoque, tal mudança é apontada por vários estudiosos beckettianos. Rubin Rabinovitz também cita essa mesma passagem de "All strange away" para marcar a ruptura da segunda para a terceira fase. O crítico ainda destaca as primeiras palavras deste texto - "Imagination dead" chamando a atenção para um novo tema que ganha destaque na prosa final de Beckett - o papel da imaginação. Ainda que "morta" ela continua a criar, aponta o crítico ${ }^{60}$. A ideia de prosseguir a partir de um "terreno arrasado" é outro velho tema da prosa beckettiana. O melhor exemplo a mencionar nesse caso é o texto Worstward Ho, analisado na segunda parte do trabalho.

De pontos de vista distintos, a maioria dos críticos chama a atenção para os três momentos que regem a prosa beckettiana. Locatelli concentra-se mais nos jogos lingüísticos estabelecidos pela obra - a paródia do cânone na primeira fase, a intratextualidade na segunda e o ataque final à própria linguagem, na tentativa de desconstruir os discursos anteriormente estabelecidos. Deleuze e Esslin veem na obra do autor esse fluxo rumo à dissipação plena, reflexão que vai ao encontro da busca declarada de Beckett pelo silêncio, pelo "cavar buracos na linguagem" até chegar ao que estaria por trás dela, ou ao Nada, como ele declara na carta a Axel Kaun ${ }^{61}$.

\footnotetext{
${ }^{59}$ Gontarski, S.E., op. cit., p. viii. "Fora de casa e pela estrada com o velho chapéu e o casaco como depois da guerra, não, isso de novo não. Cinco metros quadrados, seis de altura, sem entrada, sem saída, tentar colocá-lo aí"

${ }^{60}$ Rabinovitz, Rubin. The Self Contained: Beckett's fiction in the 1960s. In: Acheson, James \& Arthur, Kateryna (Ed.). Beckett's Later Fiction and Drama. Texts for Company. London: The Macmillan Press, 1987.

61"Como não podemos eliminar a linguagem de uma vez por todas, devemos pelo menos não deixar por fazer nada que possa contribuir para sua desgraça. Cavar nela um buraco atrás do outro, até aquilo que está a espreita por trás - seja isso alguma coisa ou nada - comece a atravessar; não consigo imaginar um objetivo mais elevado para um escritor hoje". Apud Andrade, Fábio de Souza, op. cit., p.169.
} 
Gontarski e Rabinovitz buscam esses saltos de etapa na própria temática beckettiana, apontando o momento em que o narrador abandona o velho protagonista errante de casaco e chapéu para deter-se na descrição das dimensões de um espaço. A partir desse momento, uma nova configuração será estabelecida pela prosa de Beckett.

Ainda vale mencionar o filósofo francês Alain Badiou, que também já se deteve bastante na obra do autor. Badiou destaca dois grandes momentos da obra de Beckett. O primeiro seria o período após os Textes pour rien, no qual o escritor foi tomado por um sentimento de impasse e impotência. Segundo Badiou, a saída encontrada por Beckett marcaria uma segunda etapa a partir da escrita de Comment C'est (1961), obra que marcaria uma ruptura tanto na temática quanto na condução de sua prosa. Apesar de ser possível observar traços romanescos na trilogia do pós-guerra, Badiou aponta para o esgotamento dessa forma nas obras posteriores, nas quais não seria mais possível definir à qual gênero literário pertencem. Ele defenderá a ideia de que após L'innommable o texto de Beckett adquirirá características do que ele chama de um "poema latente". A divisão de Badiou considera duas etapas apenas porque sua análise, neste momento de seu livro, concentra-se nas obras posteriores aos Textes pour rien não comentando a primeira prosa em língua inglesa ${ }^{62}$.

Apesar de nenhuma classificação dar conta da complexidade dos textos do escritor e considerando que mesmo dentro de cada período há uma unidade muito particular em cada obra, a divisão em três fases fornece um quadro geral bastante coerente para que possamos nos mover no mar da obra em prosa beckettiana, também muito extensa. Há contos do autor praticamente desconhecidos, como "A case in a thousand" e "Assumption" e uma série de textos

\footnotetext{
${ }^{62}$ Badiou, Alain. Beckett. L'incrévable désir. Paris: Hachette, 1995, p. 11-12.
} 
curtos finais, entre os quais "All strange away", "Fizzles" (1976) e "Stirrings Still"(1988).

\subsection{Discutindo a periodização}

É interessante pensar no lugar que certas obras ocupam nesta divisão. O romance Watt, por exemplo, última obra escrita em inglês antes da primeira mudança de rumo do autor, apresenta muitos pontos de contato com o tipo de narração que aparece nas novelas francesas. Os questionamentos do protagonista Watt sobre os mecanismos da linguagem e sobre a capacidade de significação das palavras anunciam, de certa forma, os impasses e angústias metalinguísticas do narrador em primeira pessoa que surge posteriormente. Captar o sentido das situações que vive já é algo central em Watt, como no momento em que ele reflete sobre a passagem dos afinadores de piano pela casa de seu mestre, o Sr. Knott:

Thus the scene in the music room, with the two Galls, ceased very soon to signify for Watt a piano tuned, an obscure family and professional relation, an exchange of judgments more or less intelligible, and so on, if indeed it had ever signified such things, and became a mere example of light commenting bodies, and stillness motion, and silent sound, and comment comment.

This fragility of the outer meaning had a bad effect on Watt, for it caused him to seek for another, for some meaning of what had passed, in the image of how it had passed. [...]

But what was this pursuit of meaning, in this indifference to meaning? And to what did it tend? These are delicate questions ${ }^{63}$.

63 Beckett, S. Watt. Ed. Chris Ackerley. London: Faber \& Faber, 2009, p.60 e 62. "Assim, a cena ocorrida na sala de música, com os dois Gall, em breve deixou de significar para Watt um piano afinado, uma obscura família e uma relação profissional, uma permuta de juízos mais ou menos inteligíveis, etc., se é que 
Watt é um romance que traz, além desses questionamentos, uma estrutura muito particular, comportando até mesmo partituras musicais, poemas, repetições que geram "curtos-circuitos" linguísticos, onomatopéias e um narrador muito especial - Sam - que diz ter ouvido a história da boca do próprio Watt através de um buraco em uma cerca de um manicômio. A semelhança com o nome do autor obviamente não é "mera coincidência" e faz parte de um jogo literário bastante comum nessas obras da primeira fase.

Em Samuel Beckett's German Diaries 1936-1937 (2011), Mark Nixon comenta o jogo de intrusão do autor em sua primeira ficção citando uma curiosa frase de Dream of Fair to Middling Women $(1992)^{64}$, obra que geraria More Pricks than Kicks:

[...] an instance of Freudian Verschreiben alerts the reader to questions of who is speaking and to the true relationship between the narrator and Belacqua. When the reader is asked, 'No but surely you see now what he am?', the inharmonious interplay of personal pronouns removes the differentiation that had previously distinguished narrator (and, potentially, author) and protagonist ${ }^{65}$.

Apesar do narrador de Watt não se confundir diretamente com o protagonista, vemos que, em suas primeiras obras em prosa, há

realmente alguma vez significara tais coisas, e se tornou um simples exemplo de corpos que faziam comentários ligeiros, e de movimento imóvel e de som silencioso, e de comentário de comentário.

Essa fragilidade do significado exterior exercia um mau efeito sobre Watt, pois levava-o a procurar outro, algum significado do que se tinha passado, na imagem de como se tinha passado[...]

Mas o que era essa perseguição do significado, nessa indiferença para com o significado? E para que tendia? Trata-se de perguntas delicadas". (Beckett, S. Watt. Trad. Manuel Resende. Lisboa: Assírio \& Alvim, 2005, p. 81 e 84).

${ }^{64}$ Esta obra foi publicada apenas em 1992. Beckett tentou publicá-la, sem êxito, em 1932, logo após a escrita, mas renegou o trabalho posteriormente. O escritor, no entanto, autorizou que o livro fosse publicado após sua morte.

65 Nixon, Mark. Samuel Beckett's German Diaries (1936-1937). London: Continuum, 2011, p. 12. "Um exemplo do Verschreiben Freudiano alerta o leitor para questões em torno de quem está falando e também para a verdadeira relação entre o narrador e Belacqua. Quando o leitor é questionado, 'não, mas certamente você vê agora o que ele sou?', a interação desarmoniosa dos pronomes pessoais remove a diferenciação que previamente distinguia o narrador (e, potencialmente, o autor) e o protagonista". 
um jogo ficcional que marca a presença do autor. Nixon vê em Dream of fair to middling women a busca de Beckett por uma escrita que o incluísse no texto ao mesmo tempo em que escondesse certas referências autobiográficas que se revelariam nas experiências de seu protagonista - Belacqua. Essa tendência, segundo Nixon, atravessa a obra de Beckett e também está presente em textos mais tardios, como o romance Malone Meurt, que trabalha com a forma do diário. De acordo com sua análise das notas de viagem do escritor, o Beckett dos anos 30 buscava uma poética, um estilo, e refletia muito mais sobre o processo de escrita do que o praticava. Já nesses diários, o crítico observa a busca por uma simplificação da linguagem. Nixon ressalta que o hábito de manter um diário foi um primeiro passo criativo na direção de um estilo de escrita que iria apagar as fronteiras entre autobiografia e ficção ${ }^{66}$.

O jogo narrativo presente em Dream of fair to middling women, entretanto, também pode estar associado ao estilo virtuosístico e à atmosfera mais cômica dessas primeiras obras, mais especificamente More Pricks than Kicks e Murphy. Ambas são marcadas por um tipo semelhante de intrusão narrativa, como veremos agora.

Em More Pricks than Kicks e em Murphy, o narrador frequentemente se intromete na narrativa para comentar sua história. A diferença está na maneira com a qual ele o faz e em como as características dessa intervenção modificam-se com o decorrer das obras em prosa. A atmosfera mais colorida dos contos e primeiros romances em inglês é substituída pelo tom angustiado em que se move o narrador das novelas até os fragmentos dos Textes pour rien.

${ }^{66}$ Idem, p. 36. 
Em More Pricks than Kicks, o narrador se considera um velho amigo de Belacqua, protagonista dos contos, e usa um artifício gerador de cumplicidade com o leitor, comentando atitudes e pensamentos do protagonista, como neste trecho de "Ding-Dong" em que descreve as feições da mulher que tenta vender assentos no céu para Belacqua: "The features were null, only luminous, impassive and secure, petrified in radiance, or words to that effect, for the reader is requested to take notice that this sweet style is Belacqua's" ${ }^{\prime 67}$.

Já em Murphy, o narrador refere-se aos personagens como fantoches em suas mãos, à exceção do protagonista, e demonstra sua superioridade em relação a eles, como neste trecho, no qual enfatiza ter melhorado ou aprimorado a história pregressa de Celia até seu encontro com Murphy, na ocasião da conversa da mesma com seu avô, Mr. Kelly: "Celia's account, expurgated, accelerated, improved and reduced, of how she came to have speak of Murphy, gives the following"68. Este modelo de frase é recorrente no romance. O narrador apenas troca o nome do personagem dono do discurso. Em Murphy, essa superioridade narrativa se dá em tom paródico como uma forma de ironizar a forma de narrar dos romances tradicionais, ricos em detalhes. A descrição física de Celia no segundo capítulo também cumpre essa função. Há ainda comentários do narrador que antecipam o que virá em capítulos subsequentes, um tipo de intervenção que Chris Ackerley relaciona com o método de narrar do autor de Tom Jones, Henry Fielding ${ }^{69}$.

\footnotetext{
${ }^{67}$ Beckett, S. "Ding-Dong". In: Samuel Beckett. The Grove Centenary Edition. Vol. IV: Poems, Short Fiction, Criticism. New York: Grove Press, 2006, p.106. "As feições eram nulas, apenas luminosas, impassíveis e confiantes, petrificadas em seu esplendor, ou palavras com este efeito, pois pedimos que o leitor note que este doce estilo é o de Belacqua".

${ }^{68}$ Beckett, S. Murphy. In: Samuel Beckett. The Grove Centenary Edition. Volume I. Novels. New York: Grove Press, 2006, p.10. "Expurgado, acelerado, melhorado e reduzido, o relato de Celia sobre como se viu forçada a mencionar Murphy, resultou no seguinte". (Beckett, S. Murphy. Trad. Fábio de Souza Andrade. São Paulo: Cosac Naify, 2013, p.13)

${ }^{69} \mathrm{Na}$ obra Demented Particulars. The Annotated Murphy, Ackerley rastreia minuciosamente todas as referências presentes neste romance - filosóficas,
} 
Na obra Beckett's Eighteenth century (2002), Frederick Smith também relaciona alguns expedientes beckettianos da primeira fase àqueles usados por escritores ingleses tais como Swift e Sterne, além de Fielding. Smith enfatiza que Beckett estudou literatura inglesa extensivamente no Trinity College nos anos 30 e, ao longo de sua obra, mostra diversos pontos de contato ligando Beckett aos autores ingleses do século XVIII. As proximidades seriam mais visíveis nos livros Dream of fair to middling women, More Pricks than Kicks e Murphy principalmente através dos gracejos do narrador e da cumplicidade que se estabelece com o leitor, estratégias que chamam a atenção para o jogo ficcional. Smith chega a comparar trechos de More pricks than Kicks com Tom Jones e de Malone Meurt com Tristram Shandy. Ligando Beckett a uma tradição maior da literatura em língua inglesa, a obra de Smith tem o mérito de retirar Beckett da associação direta com Joyce, enfatizando a importância dos estudos literários do escritor na produção de sua obra ${ }^{70}$.

Esse narrador-titereiro e cúmplice já se desfaz em Watt, romance no qual Beckett realmente parece estar explorando seu terreno literário em busca de uma nova voz. Não é a toa que uma grande mudança se processa logo em seguida. O estilo de narrar muda bastante com as novelas e a primeira trilogia. A adoção do francês e a escolha da primeira pessoa trazem uma cara nova para a ficção de Beckett, na qual não há mais espaço para as "brincadeiras" do narrador. Seus comentários mudam completamente de figura e estão mais centrados na angústia e impotência que o narrador sente

literárias, psicanalíticas. O método de composição desta obra aproxima-se do método de trabalho adotado por Joyce. Beckett incluiu em Murphy uma série de ideias presentes nas leituras que havia feito na época, devidamente anotadas em seus cadernos. Ackerley persegue detalhadamente essas referências. O mesmo autor fez um trabalho semelhante com o romance Watt em Obscure Locks, Simple Keys.The Annotated Watt. (ver Ackerley, C.J. Demented Particulars. The Annotated Murphy.Edinburgh: Edinburgh University Press, 2010 e Ackerley, C.J. Obscure Locks, Simple Keys. The Annotated Watt. Edinburgh: Edinburgh University Press, 2010. ).

${ }^{70}$ Ver Smith, Frederik N. Beckett and the Eighteenth-Century Novel. In: Beckett's Eighteenth Century. Great Britain: Palgrave/Macmillan Press, 2002. 
com o que conta, ou tenta contar. Vejamos um trecho dos Textes pour rien:

Laisse, j'allais dire laisse tout ça. Qu'importe qui parle, quelqu'un a dit qu'importe qui parle. Il va y avoir un départ, j'en serai, ce ne sera pas moi, je serai ici, je me dirai loin, ce ne sera pas moi, je ne dirai rien, Il va y avoir une histoire, quelqu'un va essayer de raconter une histoire. Oui, foin de démentis, tout est faux, Il n'y a personne, c'est entendu, il n'y a rien, foin de phrases, soyons dupe, dupe de temps, de tous le temps, en attendant que ça passe, que tout soit passe, que les voix se taisent, ce n'est que des voix, que des mensonges. ${ }^{71}$

James Knowlson e John Pilling já disseram que os Textes pour rien seriam uma espécie de divisor de águas entre o romance L'innommable e os textos em prosa final de Beckett ${ }^{72}$. A obra guarda muitas semelhanças com o romance. Mesmo após ter declarado que a escrita desses fragmentos foram uma tentativa de escapar da atitude de desintegração à qual L'innommable o teria levado, Beckett ainda teria fôlego para a escrita de Comment C'est $(1961)^{73}$.

Da mesma forma com a qual apontamos em Watt, Comment C'est também fica no meio do caminho entre o universo da errância presente nas narrativas em primeira pessoa e uma exploração da linguagem mais próxima das obras finais, além de ser uma obra "ditada" ao seu narrador, ou seja, novamente aqui a autoridade

\footnotetext{
${ }^{71}$ Beckett, S. Nouvelles et Textes pour rien. Paris: Les Éditions de Minuit, 1958, p. 129. "Deixe, eu ia dizer deixe tudo isso. Que importa quem fala, alguém disse que importa quem fala. Vai haver um começo, estarei lá, não serei eu, estarei aqui, direi que estou longe, não serei eu, não direi nada, vai haver uma história, alguém vai tentar contar uma história. Sim, sem mais desmentidos, tudo é falso, não há ninguém, está entendido, não há nada, sem mais frases, sejamos joguetes, joguetes do tempo, de todos os tempos, esperando que isso passe, que tudo seja passado, que as vozes se calem, são apenas vozes, apenas mentiras".

${ }^{72}$ Ver Pilling, John. Texts for nothing. In: Knowlson, James \& Pilling, John. Frescoes of the skull: the later prose and drama of Samuel Beckett. London: John Calder, 1979.

${ }^{73} \mathrm{~A}$ declaração à qual me refiro foi dada na mesma entrevista já citada, concedida a Israel Shenker: "A última das coisas que escrevi, os Textes pour rien, foi uma tentativa de escapar da atitude de desintegração, mas falhou". Apud Andrade, Fábio de Souza, op. cit., p.186.
} 
narrativa é atribuída a uma outra instância, representada por essa voz. A frase "je le dis comme je l'entends" permeia a narrativa de Pim e Bom, marcando a presença da voz que assombra os personagens beckettianos sobretudo, mas não exclusivamente, a partir de L'innommable. A voz que se dirige a um personagem passa a ser parte essencial de uma obra como Company, já na última etapa da prosa do autor.

A estrutura de Comment C'est também se assemelha bastante às obras da fase final, uma vez que a história é narrada de forma bastante fragmentada, em pequenos parágrafos. Apesar de ter recebido a denominação de romance, fica difícil ver a obra dentro desses limites. Com o passar do tempo, o autor veio reduzindo seus textos e aproximando-se de formas breves e mais condensadas de narrar. A sonoridade presente nestes últimos trabalhos também é digna de nota e muitos estudiosos do autor já escreveram sobre a aproximação entre poesia e prosa nesta etapa ${ }^{74}$. Há ainda a aproximação com o drama, gênero que Beckett explorou com maestria, transformando essa última fase beckettiana em um período difícil de estudar sem que se recorra também aos seus últimos trabalhos teatrais. A força imagética, os sons e passagens de textos em prosa semelhantes a rubricas são muito presentes nesta fase. $O$ hibridismo de gêneros é uma marca nesses textos finais e abriu portas para que alguns desses textos em prosa migrassem para outros meios ${ }^{75}$.

\footnotetext{
${ }^{74}$ Marjorie Perloff e Enoch Brater são dois exemplos de críticos que se detiveram bastante sobre esta relação. A primeira em ensaios como "Between verse and prose: Beckett and the New Poetry", "Space of a Door: Beckett and the Poetry of Absense" e "Une voix pas la mienne: French/English Beckett and the French/English Reader"; e o segundo em livros como The drama in the text. Beckett's late fiction e Beyond minimalism. Beckett's late style in the theater.

75 É o caso de Le dépeupleur. O texto foi levado aos palcos em uma elogiada adaptação com direção de Lee Breuer e participação de David Warrilow, conhecido ator beckettiano (Nova York, 1975). (Ver sobre o assunto Kalb, Jonathan. The gamble of staging prose fiction. In: Beckett in performance. Cambridge: Cambridge University Press, 1989). A mesma obra ainda serviu de inspiração para que o artista plástico Bruce Nauman elaborasse obras como Three Dead End Adjacent
} 
As mudanças sofridas pela prosa do autor e que nos permitem vê-la em três fases principais não ocorreram abruptamente. Na carta a Axel Kaun, Beckett explicita uma espécie de projeto literário ao dizer que o objetivo maior de um escritor naquele momento seria essa escavação da linguagem, a tentativa de chegar ao que está por trás das palavras. Nela, ele também diz que escrever em inglês estava se tornando difícil e sem sentido para ele. A carta é de 1937 e a adoção do francês em 1945 parece ser uma tentativa de começar a por em prática esse projeto de forma mais contundente.

A língua francesa lhe daria a liberdade necessária para se distanciar da tradição literária de língua inglesa, tão entranhada no autor. O momento da escolha do francês também ocorre no final da Segunda Guerra Mundial quando Beckett já havia escolhido a França como seu país de morada. O narrador- protagonista que vaga por cidades irreconhecíveis, dono apenas de uns poucos objetos além de seu casaco e chapéu também está inserido neste contexto histórico. Beckett precisou de uma nova língua para dar conta da atmosfera deste momento, sombria e desesperançada. O romance Watt foi escrito enquanto o autor se refugiava em Roussilon, no interior da França, quando escapou da Gestapo. O autor fazia parte de um grupo de Resistência francês ${ }^{76}$. Com o final da guerra, ele se estabelece em Paris e começa a escrever em francês. Em um período de cinco anos, de 1945 a 1950, Beckett compõe as obras que o tornariam célebre. Além das novelas e da trilogia romanesca do pós-guerra, ele também escreve a peça En attendant Godot (1952). Este é um período

Tunnels, Not Connected (1979 e 1981). (Ver sobre o assunto Benetti, Liliane. Ângulos de uma caminhada lenta: exercícios de contenção, reiteração e saturação na obra de Bruce Nauman. Tese apresentada ao Programa de Pós-Graduação em Artes Visuais.São Paulo: ECA/USP, 2013)

${ }^{76}$ Knowlson descreve esse período no décimo terceiro capítulo da biografia do autor - "Refuge in Roussilon 1942-5". (Knowlson, J., op. cit., p. 291-308) 
extremamente importante da obra de Beckett, o chamado siège in the room. Anos mais tarde, após ver todos os seus principais trabalhos traduzidos para diversas línguas, o autor ainda ganharia o prêmio Nobel de Literatura (1969). É sabido que Beckett se referiu ao prêmio como "uma catástrofe" ${ }^{177}$, entretanto, a despeito de sua vontade, seu nome já ganhara o mundo.

Quanto à prosa, o narrador em primeira-pessoa parece ter sido explorado ao máximo nesta fase e o autor procurou uma outra forma para continuar. Seu questionamento em torno de como narrar, "como dizer" o mundo transforma-se na constatação de que dizer é "dizer mal" e representar é "representar mal", restando ao artista apenas acolher a falha e "falhar melhor" - "Say for be said. Missaid. From now say for be missaid" - diz o narrador de Worstward Ho. Esses temas são bastante presentes na segunda trilogia beckettiana, que passamos a analisar agora.

Tornou-se comum dizer que a busca de Beckett pelo silêncio é bastante ruidosa, já que ela se dá pela exploração intensa e incessante de todas as possibilidades da palavra. Para além da palavra, a fase final da prosa beckettiana é também uma exploração de sons, imagens, luzes e vozes. Entramos no terreno do manicômio do crânio.

${ }^{77}$ Idem, p. 505-6 


\title{
II- NO MANICÔMIO DO CRÂNIO: A "SEGUNDA TRILOGIA" BECKETTIANA
}

\begin{abstract}
Esse crânio já teve língua um dia, e podia cantar. E o crápula o atira aí pelo chão, como se fosse a queixada de Caim, o que cometeu o primeiro assassinato. Pode ser a cachola de um politiqueiro, isso que esse cretino chuta agora; ou até o crânio de alguém que acreditou ser mais que Deus. [...]

Olá, pobre Yorick! Eu o conheci, Horácio. Um rapaz de infinita graça, de espantosa fantasia. Mil vezes me carregou nas costas; e agora, me causa horror só de lembrar! Me revolta o estômago! Daqui pendiam os lábios que eu beijei não sei quantas vezes. Yorick, onde andam agora as tuas piadas? Tuas cambalhotas? Tuas cantigas? Teus lampejos de alegria que faziam a mesa explodir em gargalhadas? Nem uma gracinha mais, zombando da tua própria dentadura? Que falta de espírito! Olha, vai até o quarto da minha grande Dama e diz a ela que, mesmo que se pinte com dois dedos de espessura, este é o resultado final; vê se ela ri disso!
\end{abstract}

Shakespeare,

Hamlet.

As três obras que iremos comentar agora trazem o leitor para um mundo que trata de temas anteriores da prosa do autor de uma maneira inteiramente nova. O objetivo aqui é apresentar o universo da segunda trilogia em prosa do autor. Se a imagem crua do crânio é frequentemente associada a uma reflexão sobre a morte, na prosa final de Beckett ela é a fonte central de criatividade. Finitude e "exploração da mente" se retroalimentam nesta etapa - "Imagination dead imagine". 


\subsection{Company, imaginação soberana na escuridão}

A voice comes to one in the dark. Imagine.

Em Company, um homem deitado de costas no escuro ouve uma voz que, por sua vez, parece narrar cenas da vida deste sujeito. Tal situação, entretanto, não pode ser comprovada, já que o narrador aventa a possibilidade dessa mesma voz estar se dirigindo a um outro que também poderia estar ali, na mesma escuridão. Os parágrafos são relativamente curtos, com poucas exceções, nos quais este narrador vai descrevendo a situação do homem que está ali além de comentar a própria feitura e proposição de seu texto:

A voice comes to one in the dark. Imagine.

To one on his back in the dark. This he can tell by the pressure on his hind parts and by how the dark changes when he shuts his eyes and again when he opens them again. Only a small part of what is said can be verified. As for example when he hears, You are on your back in the dark. [...] That then is the proposition. To one on his back in the dark a voice tells of a past. With occasional allusion to a present and more rarely to a future as for example, You will end as you now are. And in another dark or in the same another devising it all for company. Quick leave him ${ }^{78}$.

A abertura da obra condensa tudo o que leremos na sequência. O desenvolvimento dessa situação se dará através das manifestações

\footnotetext{
78 Beckett, S. Company. In: Samuel Beckett. The Grove Centenary Edition. Vol IV. Poems. Short Fiction. Criticism. New York: Grove Press, 2006, p. 427. As citações de IIl Seen IIl Said e Worstward Ho também serão retiradas desta edição. Sendo assim, a partir de agora indicarei apenas o nome da obra e a página correspondente à citação. O mesmo será feito com as citações das traduções cuja referência já foi citada: "Uma voz chega a alguém no escuro. Imaginar.

A alguém deitado de costas no escuro. Isso ele pode dizer pela pressão nas partes traseiras e pela mudança do escuro quando ele fecha os olhos e de novo quando os abre de novo. Só uma pequena parte do que é dito pode ser verificada. Como por exemplo quando ele ouve, Você está deitado de costas no escuro.[...]. Aquela então é a proposição. A alguém deitado de costas no escuro uma voz conta de um passado. Com alusões ocasionais a um presente e mais raramente a um futuro como por exemplo, Você acabará como está agora. E num outro escuro ou no mesmo um outro imaginando tudo por companhia. Depressa deixá-lo" (Companhia, op. cit., p. 27)
} 
da voz e dos comentários do narrador. Essa capacidade de síntese é uma característica da prosa final de Beckett. A última frase do trecho - "Depressa deixá-lo" - traz a marca daqueles comentários sobre o narrado presentes em toda prosa do autor. Deixar depressa o sujeito no escuro? Por quê? O narrador parece estar se referindo à composição que cria. É como se as imagens fossem surgindo e o leitor acompanhasse o processo. É preciso deixá-lo depressa e ir ao passo seguinte da composição - definir a voz - o que ocorre já no terceiro parágrafo: "Use of the second person marks the voice" ${ }^{\prime 79}$.

A voz verbatim dirige-se diretamente ao sujeito, sempre em segunda-pessoa, trazendo estas supostas lembranças do passado. A função da voz é fazer com que o sujeito se lembre do que é narrado, algo que nunca acontece. Há uma forte relação entre voz e memória, fracassada contudo, já que o sujeito nunca se manifesta para conferir veracidade ao que a voz narra:

Might not the voice be improved? Made more companionable [...] To have the hearer have a past and acknowledge it. You were born on an Easter Friday after long labour. Yes I remember. The sun had not long sunk behind the larches. Yes I remember. As best to erode the drop must strike unwavering. Upon the place beneath ${ }^{80}$.

A expressão "depressa deixá-lo" aparecerá novamente nos parágrafos 28 e 57: "Who asks in the end, Who asks? And in the end answers as above? And adds long after to himself, Unless another still. Nowhere to be found. Nowhere to be sought. The unthinkable last of all. Unnamable. Last person. I. Quick leave him. ${ }^{81 "}$ e "What a

\footnotetext{
79 Company, p. 28. "Uso da segunda-pessoa marca a voz" (Companhia, p. 28)

80 Company, p. 438. "A voz não poderia ser melhorada? Ficar mais propensa a companhia. [...] Fazer com que o ouvinte tenha um passado e o reconheça. Você nasceu numa Sexta-Feira Santa depois de um longo trabalho de parto. Sim eu me lembro. O sol acabara de se pôr atrás dos lariços. Sim eu me lembro. Para melhor erodir o pingo deve bater sem se desviar. No que está embaixo" (Companhia, p. 44)

${ }^{81}$ Company, p. 434. "Quem pergunta no fim, Quem pergunta? E no fim responde como acima? E acrescenta muito depois para si mesmo, A menos que um outro
} 
further addition to company that would be! Yet another still devising it all for company. Quick leave him ${ }^{82 " .}$

A retomada da expressão parece adquirir outros sentidos na medida em que aparece. Se no início parecia referir-se ao sujeito no escuro, em sua segunda menção parece referir-se ao narrador da obra, denominado aqui "o impensável último de todos. Inominável. Última pessoa. Eu". O narrador de Company seria o último na cadeia dos narradores beckettianos? No momento em que se parece chegar a essa ideia surge a frase "depressa deixá-lo". A expressão sempre parece indicar o abandono de uma possível conclusão, de um possível fechamento.

A primeira incursão da voz ocorre no sexto parágrafo e começa com a frase: "A small boy you come out of Connoly's Stores holding your mother by the hand" ${ }^{83}$. O trecho vai evocar uma lembrança já presente em outras obras de Beckett, como a novela "La fin" e o romance Malone Meurt. A situação consiste na pergunta que um menino faz à mãe sobre a distância do céu em relação a eles, ao que a mãe responde com rispidez, repelindo-o.

Na biografia de Beckett escrita por James Knowlson, há um rastreamento de como diversas situações e pessoas marcantes da vida do autor aparecem em sua obra. Nas lojas Connoly, por exemplo, que também aparecem na peça All That Fall (1957), a mãe do escritor, May, costumava fazer compras. O biógrafo ainda comenta o que Beckett definiu como "imagens obsessivas" que o perseguiam, em sua maioria associadas à infância. É o caso do

ainda. Em lugar nenhum a ser encontrado. Em lugar nenhum a ser procurado. 0 impensável último de todos. Inominável. Última pessoa. Eu. Depressa deixá-lo. (Companhia, p. 38).

${ }^{82}$ Company, p. 449. "Que acréscimo adicional a companhia isso ia ser! Ainda um outro ainda inventando isso tudo por companhia. Depressa deixá-lo" (Companhia, p. 61)

${ }^{83}$ Company, p. 428. "Um garotinho você sai das lojas Connoly segurando a mão de sua mãe". (Companhia, op. cit., p. 29) 
homem de mãos dadas com o menino, uma das imagens-chave de Worstward Ho. Knowlson a associa com a boa relação que Beckett tinha com o pai ${ }^{84}$.

Para quem conhece a biografia do autor, é fácil identificar diversas cenas de cunho autobiográfico em Company, obra na qual essas memórias aparecem em maior quantidade. Além da resposta áspera da mãe que marca o menino, há a menção ao nascimento do personagem em uma Sexta-Feira Santa enquanto o pai, que não suportava estar presente durante o trabalho de parto, sai para fazer uma caminhada ${ }^{85}$. As memórias associadas às vivências com o pai são as mais frequentes. A voz ainda traz lembranças dos passeios realizados entre os dois e do momento em que o menino tenta aprender a nadar, olhando do alto de uma rocha para o rosto amável do pai que o incita a pular na água: "You look down to the loved trusted face. He calls you to jump. He calls, Be a brave boy. The red round face. The thick moustache. The greying hair" ${ }^{\prime 86}$. Segundo Gontarski, esta última memória atormentou o escritor até seus últimos dias. Ele teria sonhos recorrentes nos quais se via tendo que mergulhar entre as rochas ${ }^{87}$.

Apesar da clara relação que se pode estabelecer entre vida e obra, Gontarski critica a leitura de Company como uma biografia cifrada. Para ele, esse tipo de interpretação negaria a característica fundamental desses últimos textos - o papel da imaginação e o trabalho da mente criadora, conforme já apontamos. O crítico ainda ressalta que as alusões autobiográficas não são maiores que as

\footnotetext{
${ }^{84}$ Knowlson, James. Preface; Images of Childhood (1906-15). In: Damned to Fame. The life of Samuel Beckett. New York: Grove Press, 1996.

${ }^{85}$ Esta situação também aparece em "Premier Amour". Nesta novela, o narradorprotagonista decide abandonar a casa em que morava com Lulu, grávida de seu filho, no momento em que ela dá à luz. A novela termina enquanto ele se distancia da casa, ainda ouvindo seus gritos em trabalho de parto.

86 Company, p. 432. "Você olha para baixo para o amado e confiável rosto. Ele grita para você pular. Ele grita, Seja um menino corajoso. O rosto redondo e vermelho. O bigode farto. O cabelo ficando grisalho." ( Companhia, p. 34)

${ }^{87}$ Gontarski, op. cit., p. xviii- xix. O crítico lembra que a mesma cena aparece no romance Watt e em um poema de 1930, "For Future Reference".
} 
alusões literárias que Beckett utiliza em sua obra e que ambas fazem parte de um mesmo contexto no qual a imaginação é soberana: "Childhood memories, like literary allusions, are 'figments', 'traces', 'fables' or 'shades', a mix of memory, experience, desire and imagination. Company then, like the other 'closed spaces' tales, is neither memoir nor autobiography, but a set of devised images of one devising images." ${ }^{88}$

Enoch Brater segue a mesma linha mostrando a imensa quantidade de autorreferências literárias presentes em Company. Para este crítico a frase "Yes, I remember" - que o narrador deseja que o sujeito diga - poderia até mesmo ser lida como uma exclamação do próprio leitor que, conhecedor da obra de Beckett, recorda-se de trabalhos anteriores na medida em que lê Company, um de seus últimos textos ${ }^{89}$. Poderíamos dizer que a obra joga com essas três instâncias - biografia, ficção e recepção.

H. Porter Abbott sugere que a biografia de Beckett realizada por Deirdre Bair - Samuel Beckett: a Biography (1978), poderia ter servido de estímulo para que o autor escrevesse Company como uma espécie de resposta ${ }^{90}$. É uma especulação interessante pois o que a obra faz é justamente questionar o que poderia ser tomado como "real", inserindo todas as memórias no plano da imaginação. Abbott é um dos críticos beckettianos que estuda as relações entre autobiografia e ficção. Ele aproxima Company dos textos de Santo Agostinho e William Wordsworth ${ }^{91}$. A obra de fato coloca em pauta a ideia de reconstrução de uma história de vida através da memória e

88 Idem, p. xxi. "As memórias de infância, assim como as alusões literárias são invenções, traços, fábulas ou sombras, uma mistura de memória, experiência, desejo e imaginação. Companhia, então, como as outras narrativas dos 'espaços fechados', não é nem uma coleção de memórias, nem uma autobiografia, mas um conjunto de imagens imaginadas por alguém que imagina".

89 Brater, Enoch. The Company Beckett Keeps: The Shape of Memory and One Fablist's Decay of Lying. In: Beja, Morris; Gontarski, S.E. \& Astier, Pierre (Ed). Samuel Beckett: Humanistic Perspectives. Ohio: Ohio State University Press, 1982. ${ }_{90}$ Abbott, Porter H. Beckett writing Beckett. The author in the autograph. Ithaca e London: Cornell University Press, 1996, p. 18-9.

${ }^{91}$ Abbott, Porter H., op. cit. 
da escrita. No entanto, é importante observar que as memórias (manifestações da voz) são colocadas em dúvida pela incapacidade do ouvinte em reconhecê-las e a escrita (comentários do narrador) está repleta de questionamentos. O texto aponta justamente para as falhas dessa empreitada. Ainda assim, o foco da obra está em um sujeito que ouve suas supostas memórias. Não podemos negar que há uma tentativa em valorar essas recordações. Beckett problematiza essa questão: a capacidade da linguagem e da escrita em conferir algum sentido ou reconstruir uma história de vida.

O estudioso de Beckett irá notar essas recorrências e relacionálas à vida pessoal do escritor como um dado a mais de aprofundamento no universo beckettiano. No entanto, aquele que não o fizer, não será prejudicado na leitura dos textos. O conhecimento da biografia aprimora, mas não constitui um dado fundamental para que se aprecie Company, ainda que a recepção da obra possa se alterar dependendo dos conhecimentos extraliterários do leitor. A situação proposta sustenta-se por si só. Torna-se necessário, contudo, chamar a atenção para o caráter autobiográfico do texto uma vez que esta é a obra do autor em que ele é mais evidente.

Como foi dito anteriormente, além dos parágrafos nos quais a voz traz à tona essas supostas memórias do sujeito deitado no escuro, existem outros nos quais um narrador discorre sobre a cena ali apresentada, comentando as inflexões da voz, as possíveis dimensões do espaço, a alternância entre claridade e escuridão etc. Esta instância imagina, inclusive, o criador desta situação/narrativa e reflete sobre onde estaria esse criador, em que posição, sob qual luz, a que distância de sua criatura/ouvinte, etc. Detalhando o "enredo" de Company há, portanto, o homem deitado de costas no escuro, a voz que chega a seus ouvidos, o criador que imagina toda essa cena ao mesmo tempo em que faz parte dela, e uma instância narrativa 
mais distante, condutora do texto, que narra todo esse processo de imaginar e compor as cenas que descreve.

Vimos que, com as devidas diferenças, os comentários do narrador estão presentes na ficção do autor desde More Pricks than Kicks. Em uma obra como Company, a diferença em relação a estes comentários está no papel central que eles ocupam em comparação com textos das fases anteriores, uma vez que a escolha, neste momento, é mostrar como se constituem as imagens, como elas se transformam em palavras e como o cérebro - o "germ of all" que aparece em Worstward Ho - executa esse processo no ato da criação. Nesta segunda trilogia, Beckett passa a tratar dos bastidores do ato criativo. As funções do olho, por exemplo, como captador de imagens são essenciais em IIl Seen Ill Said. Em Company, a imaginação assume o papel central, ela é a própria companhia buscada.

A voz é uma antiga companheira do protagonista beckettiano e Company é a obra em prosa na qual ela ganha mais destaque. Mais presente a partir do romance L'innommable, ela é marcante nos fragmentos dos Textes pour rien e também em Comment C'est. Nestas obras o protagonista refere-se a ela como uma força que o obriga a continuar seu discurso contra sua vontade. É como se ele não estivesse mais sob controle, tornando-se um boneco de ventríloquo desta voz. O próprio narrador dos Textes pour rien se compara a um boneco de ventríloquo no oitavo fragmento dessa obra: "... je ne suis ici qu'une poupée de ventriloque, je ne sens rien, je ne dis rien, il me tient dans ses bras et il fait remuer mes lèvres avec une ficelle..." ${ }^{\prime 2}$.

Aqui em Company a voz se manifesta diretamente no texto e o leitor pode acompanhar o que ela traz ao seu ouvinte, diferentemente dessas outras obras nas quais ela é apenas mencionada e pode ser

\footnotetext{
${ }^{92}$ Beckett, S., op. cit., p. 170-1 "... aqui eu sou apenas um boneco de ventríloquo, não sinto nada, não digo nada, ele me segura em seus braços e faz meus lábios se moverem com um barbante".
} 
vista como uma voz interna do próprio narrador que o obriga a continuar sua narrativa.

Sob este aspecto, Company guarda mais semelhanças com alguns textos teatrais de Beckett como Krapp's last tape (1958) e That time (1976). Também nessas peças a voz desempenha um papel fundamental. Na primeira, Krapp aos 69 anos ouve gravações que havia feito quando era mais jovem. O personagem tinha como costume fazer um balanço de sua vida a cada ano e gravar a si mesmo falando sobre estes fatos. O espectador desta peça acompanha as reações do protagonista enquanto, juntamente com ele, ouve essas gravações. As diferentes vozes que constituem Krapp são o cerne da peça. Em That Time, um sujeito do qual só vemos a cabeça também ouve três vozes distintas que se intercalam narrando cenas de sua vida.

A configuração escolhida para a manifestação da voz em Company assemelha-se a essas peças. No entanto, a associação da voz com uma força perturbadora que impede que o personagem atinja o silêncio, marca dos textos em prosa anteriores, também aparece aqui. No décimo quarto parágrafo, há uma explicação de como tudo teria começado para o protagonista de Company:

Slowly he entered dark and silence and lay there for so long that with what judgement remained he judged them to be final. Till one day the voice. One day! Till in the end the voice saying, You are on your back in the dark. Those its first words. Long pause for him to believe his ears and then from another quarter the same. Next the vow not to cease till hearing cease. You are on your back in the dark and not till hearing cease will this voice cease. Or another way. As in shadow he lay and only the odd sound slowly silence fell and darkness gathered. That were perhaps better company. For what odd sound? Whence the shadowy light? ${ }^{33}$

\footnotetext{
${ }^{93}$ Company, p. 431-2. "Lentamente ele entrou no escuro e no silêncio e se deitou lá por tanto tempo que com o juízo que restava julgou-os finais. Até que um dia a voz. Um dia! Até que por fim a voz dizendo, Você está deitado de costas no escuro. Essas as suas primeiras palavras. Pausa longa para ele acreditar nos seus ouvidos e então de outro canto o mesmo. A seguir o voto de não cessar até a audição cessar. Você está deitado de costas no escuro e só quando a audição cessar esta voz vai
} 
Apesar de o narrador sugerir uma outra possibilidade para esta situação inicial na parte final do trecho - "or another way" - o que põe em dúvida o que foi dito, o que se tem aqui é a velha voz que atormenta os personagens beckettianos e impede o silêncio, criando uma condição infernal. Enquanto ele puder ouvir ela estará presente - "Next the vow not to cease till hearing cease". No parágrafo anterior, o narrador fala da esperança que o sujeito alimenta de que a voz cesse: "At each slow ebb hope slowly dawns that it is dying. He must know it will flow again. And yet at each slow ebb hope slowly dawns that it is dying" ${ }^{\prime 4}$. Aqui podemos ler o desejo do sujeito por um descanso, sempre impedido pelo retorno da voz. Gostaria de salientar, portanto, que apesar de sua nova configuração, a voz mantém esse caráter perturbador.

O uso da repetição, como no trecho acima, é frequente na obra. Em passagens como essa, a sonoridade do texto chama a atenção, gerando uma forte musicalidade se lido em voz alta. Além das repetições, há diversos exemplos que poderíamos citar em relação à sonoridade: "Sole sound in the silence your footfalls"; "The swell sways it under and sways it up again"; "Some soft thing softly stirring soon to stir no more"; "And then there was no then so there is no now"; "Can the crawling creator crawling in the same create dark as his creature create while crawling? ${ }^{95 "}$

cessar. Ou de outra forma. Enquanto estava deitado na sombra e só raros sons lentamente o silêncio caiu e a escuridão se firmou. Isso talvez fosse melhor companhia. Pois quais raros sons? De onde a luz sombria?" (Companhia, op. cit., p. 34)

${ }^{94}$ Idem, p. 431. "A cada refluxo lento a esperança desponta lentamente de que ela esteja morrendo. Ele deve saber que ela fluirá outra vez. E entretanto a cada refluxo lento a esperança desponta lentamente de que ela esteja morrendo". (Companhia, op. cit., p 33)

${ }^{95}$ Ibidem, p. 430, 432, 432, 433 e 446. "Único som no silêncio seus passos"; "A ondulação o balança para baixo e para cima outra vez"; "Alguma coisa suave suavemente se mexendo para logo não mais se mexer"; "Como então não havia então também não há nenhum agora"; "Pode o criador rastejante rastejando no mesmo escuro criado que sua criatura criar enquanto rasteja?" (Companhia, op. cit., p.32, 34, 34, 36, 56). 
É impossível não notar o trabalho com os sons realizado por Beckett. Para além da sonoridade, a obra apresenta diversos pontos de contato com a poesia - múltiplas possibilidades de significado, rimas, elipses, inversões gramaticais, força imagética. As escolhas da composição extrapolam os limites da linguagem discursiva, mexendo não apenas com nosso entendimento do texto, mas também com nossos sentidos. Sobre esse assunto, vale mencionar o artigo em que Marjorie Perloff analisa IIl Seen IIl Said aproximando o texto do gênero lírico. Ela analisa o primeiro trecho do texto como uma estrofe e escreve sobre a ambiguidade entre poesia e prosa nessa obra ${ }^{96}$. Essa característica é comum às três obras da segunda trilogia.

Enoch Brater também chama a atenção para o papel do som nas últimas peças de Beckett em Beyond Minimalism. Beckett's late style in the theater (1987). Para ele, obras como Ohio Improptu, Rockaby e Footfalls poderiam ser vistas como apresentações de um poema no palco: "This is not drama in the shape of poetry, but poetry in the shape of drama. The experience for the audience in the theater is like the experience of reading a poem, except that in this instance the poem has been staged" ${ }^{\prime 97}$. Neste texto, Brater argumenta que a definição tradicional de gênero não se aplica às peças de Beckett, principalmente às da fase final. Ele mostra que mesmo em monólogos de peças anteriores, como En attendant Godot, Fin de partie e Happy days, já havia uma força poética, além da tendência

\footnotetext{
96 Perloff comenta a publicação de III Seen IIl Said na revista New Yorker em 1981. Apesar de designado como prosa, o texto apresentava mais características líricas, especificamente em relação a sua estrutura sonora, do que o poema "real" publicado a seu lado - Sea Noise, de Harold Brodkey. (Ver Perloff, Marjorie. Between Verse and Prose. Beckett and the New Poetry. In: Critical Inquiry 9. Chicago: The University of Chicago, 1982).

97 Brater, E. Genre under stress. In: Beyond Minimalism. Beckett's late style in the theater. New York: Oxford University Press, 1987, p. 17. "Isto não é drama na forma de poesia, mas poesia na forma de drama. A experiência do público no teatro é similar à da leitura de um poema, exceto que, neste caso, o poema foi montado".
} 
dos protagonistas em contar histórias, ou seja, uma épica dentro do drama ${ }^{98}$.

Essa mistura entre gêneros não é de se estranhar em um autor que trabalhou com quase todos eles. Beckett escreveu poemas, ensaios, peças teatrais, radiofônicas e televisivas além da extensa produção em prosa. O que parece ocorrer nesta segunda trilogia é uma confluência mais intensa entre diversos destes discursos. Além do explícito trabalho com o som, que aproxima Company de um poema, a voz nessa obra se manifesta como na peça That Time. Há ainda um forte recurso visual associado à sua manifestação, que faz com que o leitor imagine a "cena" como se ela estivesse sendo representada - a voz é acompanhada de luz. É ela a única luz na escuridão em que se encontra o sujeito - "By the voice a faint light is shed. Dark ligthens while it sounds. Deepens when it ebbs" ${ }^{\prime 99}$.

A luz direcionada a um personagem também é utilizada em Play (1964). É o próprio foco de luz que aciona a fala dos três personagens. Para além do aspecto visual, vale mencionar que, assim como a voz, a luz também pode assumir um papel perturbador. No caso de Play, os personagens são impelidos a falar quando o foco luminoso recai sobre eles. A ação da luz é agressiva. A voz acompanhada de luz também pode marcar essa intenção de incomodar o ouvinte com suas memórias.

Nos arquivos de Beckett da Universidade de Reading, é possível consultar alguns manuscritos embrionários de Company e anotações do autor sobre a composição da obra. No caderno em que Beckett

98 Kristin Morrison estuda o papel da épica dentro do drama nas peças de Beckett. O fato dos personagens contarem histórias seria uma espécie de substituição do solilóquio. Através da narração, os personagens revelariam sua interioridade ao público (Ver Morrison, Kristin. Canters and Chronicles. The use of narrative in the plays of Samuel Beckett and Harold Pinter. Chicago: Chicago University Press, 1983).

${ }^{99}$ Company, p. 432. "Pela voz uma luz fraca é emitida. A escuridão clareia enquanto soa. Aprofunda-se quando reflui". (Companhia, op. cit., p. 34) 
realizou a tradução de Company para Compagnie há um trecho muito interessante intitulado "Scenes from the past". Nele, o autor determina um momento do dia associado a sua respectiva luz (luz da tarde, luz da manhã, meio-dia, noite) para cada passagem referente às supostas memórias do ouvinte. Este trecho demonstra uma tendência dramática no momento de composição da obra ${ }^{100}$. Podemos ver que o autor pensou detalhadamente na luz que acompanharia cada uma dessas "cenas". Para o trecho referente à narração do nascimento e da caminhada com o pai na Ballyogan Road (parágrafos 9 e 27) Beckett escreve "noite". Já para os trechos referentes à Mrs. Coote e ao episódio do ouriço está escrito "tarde" (parágrafos 24 e 33). Para o momento do encontro com a moça no caramanchão temos "luz do arco-íris" (parágrafo 40).

Apesar do jogo entre luz e sombra ser uma marca da obra de Beckett como um todo, podemos notar nesses manuscritos o próprio esforço criativo do autor no sentido de imaginar os trechos acompanhados de luz, algo que evidencia um tipo de visualização próximo da criação teatral. A escolha do "homem no escuro que ouve" também sugere o papel de um espectador. Sobre esse assunto é interessante mencionar uma entrevista de Frederick Neumann concedida a Lois Oppenheim em 1992. Neumann relata uma conversa com Beckett na ocasião em que buscava a autorização do autor para sua adaptação de Company. Beckett o teria questionado sobre o que a montagem mostraria, uma vez que "tudo acontece no escuro". Neumann argumentou que essa era a própria condição do espectador que vai ao teatro, ao que Beckett respondeu: "Touché!" A autorização foi concedida e Neumann co-dirigiu uma adaptação de Company com

100 Refiro-me aos manuscritos MS 2910 e MS 1822 dos arquivos de Beckett na Universidade de Reading. 
Honora Fergusson para o Mabou Mines em 1982, grupo do qual era integrante ${ }^{101}$.

O próprio Gontarski já adaptou Company para o palco e escreveu um artigo sobre esta experiência analisando a obra e explicando por que a considera um dos textos mais dramatizáveis de Beckett $^{102}$. Jonathan Kalb também dedica um capítulo de seu livro Beckett in performance às adaptações feitas dos textos em prosa, comentando inclusive a referida montagem de Neumann ${ }^{103}$.

O principal problema enfrentado por essas montagens estava justamente em como mostrar o ator no palco - ora como ouvinte, ora como narrador, ora como voz - respeitando a ambiguidade que há no texto, no qual as figuras, apesar de apartadas, convergem para uma unidade. O sujeito estaria, assim, ouvindo a própria voz ao mesmo tempo em que refletiria sobre sua situação ali deitado no escuro. Há notícias de uma interessante adaptação apresentada no Beckett Festival de 1992 na Holanda (Amsterdã e Haia), sob a direção de Chaim Levano. Nesta montagem, o diretor optou por espalhar cadeiras em diversos níveis pelo espaço cênico. Os espectadores sentavam-se, as luzes apagavam-se e eles simplesmente ouviam o texto de Company gravado por Levano. A voz vinha de várias direções, com suas respectivas variações de luz. A proposta foi colocar o espectador diretamente na pele do ouvinte. Esta montagem

\footnotetext{
${ }^{101}$ Ver Oppenheim, Lois. (Ed). Directing Beckett. Michigan: University of Michigan Press, 1994, p. 28.

${ }^{102}$ Neste texto, Gontarski chama a atenção para o caráter "andrógino" de Company. Além de detalhar o processo de sua montagem, cuja estreia ocorreu em 1984, ele lembra que Beckett escreveu Company logo após $A$ piece of monologue - seu drama mais narrativo. Beckett estava, nesse momento, "conscientemente explorando o terreno comum entre o drama e a ficção". Ver Gontarski, S.E. Company for Company: Androgyny and Theatricality in Samuel Beckett's prose. In: Acheson, James \& Arthur, Kateryna (Ed.). Beckett's Later Fiction and Drama. Texts for Company. London: The Macmillan Press, 1987.

103 Neste livro também encontramos a análise da famosa montagem de "Le dépeupleur" com direção de Lee Breuer e participação de David Warrilow em Nova York, 1975. Ver Kalb, Jonathan. The gamble of staging prose fiction. In: Beckett in performance. Cambridge: Cambridge University Press, 1989.
} 
parece ter sido a que mais se aproximou da própria experiência da leitura da obra ${ }^{104}$.

No entanto, apesar das tentativas de adaptação e do claro hibridismo de gêneros já mencionado, Beckett decidiu que Company seria um texto em prosa. A escolha pode estar justamente na força dada ao papel da imaginação. Em uma montagem, nós vemos as cenas e na leitura, imaginamos. A montagem de Levano recriou cenicamente a experiência da leitura. O verbo "imaginar" é o verdadeiro protagonista da obra. Ele aparece isolado na primeira linha do texto quase como uma palavra de ordem. Ele dá o tom do que segue - "A voice comes to one in the dark. Imagine".

A investigação em torno do funcionamento da imaginação, essa espécie de recuo para o interior do crânio ocorre, em Company, através da retomada de diversos elementos da ficção anterior configurados em nova perspectiva. As lembranças trazidas pela voz trazem referências a diversas situações presentes em obras pregressas - o amparo no pai, a obsessão do protagonista pelos cálculos, pela contagem dos passos, o casaco e as botas típicas da figura beckettiana. No entanto, essas memórias não são reconhecidas pelo sujeito que está deitado no escuro. A identificação com elas não se concretiza. Ele não é capaz de dizer "Yes, I remember" como deseja o narrador. A movimentação e atividade do ouvinte são praticamente nulas. Esta é uma narrativa na qual não há lugar para a primeira pessoa. O sujeito não assume aquelas experiências como suas. Tanto as cenas descritas pelo narrador como as lembranças mencionadas pela voz fazem parte de um mesmo espaço fabulatório, no qual o papel do imaginar impera.

Assim como em textos anteriores, também essa narrativa é permeada por comentários sobre sua própria composição. Entretanto,

${ }^{104}$ As informações sobre a montagem de Chaim Levano foram retiradas das Folders Company dos arquivos de James Knowlson da Universidade de Reading (JEK $\mathrm{A} / 5 / 11)$. 
ao contrário dos impasses aos quais estava sujeito o narrador em primeira pessoa da fase anterior, aqui, ocorre uma capacidade de observação mais distanciada do processo de criação. Isso não significa que nesta última fase a narração não hesite. Há também intensos momentos de questionamento sobre a capacidade de perceber e transformar o que se vê ou imagina em palavras. Este assunto fica mais evidente na segunda obra dessa tríade - IIl Seen III Said - na qual a trajetória do olho que busca imagens entra em destaque. As imagens vêm e vão sem que ele consiga controlá-las e descrevê-las de forma clara. Apesar de mais objetivo e distanciado, o narrador continua impotente diante do mundo. O que ele vê é apenas bruma.

Como primeiro texto desta segunda trilogia, Company marca uma nova mudança de rumo na prosa de Beckett. O protagonista errante torna-se um sujeito imóvel, receptor da voz. O fim e o silêncio parecem estar próximos, mas a tão desejada calmaria é sempre negada ao homem beckettiano. Se o corpo parou, "o manicômio do crânio" passa a ser, por excelência, o território de novas explorações.

\subsection{Seen III Said - O olho enevoado}

Haze sole certitude.

A leitura de IIl Seen IIl Said nos leva a um espaço bem diferente daquele de Company. Nesse ponto podemos entender por que Beckett não gostava da denominação de trilogia agrupando os três textos. Há uma especificidade muito própria em cada um deles. Apesar dos temas comuns que apontamos como característicos dessa 
fase estarem presentes - o papel da imaginação e o trabalho intenso da mente criadora - a "história" que seguimos aqui nada tem a ver com a anterior. Ao contrário da trilogia do pós-guerra, na qual é possível observar um caminho percorrido pela narração em primeirapessoa de Molloy a L'innommable, aqui os textos guardam uma independência maior. Não há a sensação de reconhecimento de um protagonista que se transforma, reaparecendo na obra seguinte, impressão que se tem na primeira trilogia. Parece haver uma relação maior, por exemplo, entre a temática de IIl Seen IIl Said e Worstward Ho, no sentido do "mal dizer" a linguagem, algo que não ocorre em Company. A ligação desta última com as demais se dá mais por características como - o foco na imaginação, o trabalho da mente, os comentários do narrador sobre o narrado, o jogo acentuado de luz e sombra, a musicalidade do texto.

Em Ill Seen IIl Said, seguimos os passos de uma velha senhora que vive solitária em seu refúgio. Ela é vigiada por um olho que a observa e tenta reproduzir o que vê. $O$ olho é um personagem tão significativo na obra quanto ela. A narração alterna as cenas envolvendo a mulher com as más sucedidas empreitadas do olho em produzir uma imagem clara. O narrador coordena e comenta tanto as tentativas do olho de apreender uma imagem como as atividades realizadas pela protagonista.

Assim como Company, a obra se apresenta em diversos blocos, 61 parágrafos ao todo, como se cada um deles fosse uma retomada da tentativa de representação de uma cena. Elas escapam tanto ao olho como ao narrador. A constatação desta dificuldade está presente em todo o texto. Palavras como "calma" e "cuidado" permeiam os parágrafos.

Logo no início, ao descrever a cabana em que a mulher vive, temos: "The cabin. Its situation. Careful. On. At the inexistent centre 
of a formless place. [...] How come a cabin in such a place? How came? Careful" ${ }^{105}$. Trechos assim funcionam como uma espécie de alerta, um aviso para que o narrador siga cuidadosamente seu caminho, já sabendo de antemão que as imagens não se sustentam por muito tempo e que a qualquer momento podem desaparecer: "But quick seize her where she is best to be seized"106. Esses avisos também apontam para as falhas da própria linguagem que se usa. É preciso calma e cuidado na escolha dos termos que representarão o que se vê. Em um texto no qual a única certeza é a névoa, a bruma que menciona o narrador, também as palavras estão sob suspeita. Tornar mal dito, piorar o que se diz, tema explorado intensamente em Worstward Ho, começa a surgir de forma significativa já aqui. $\mathrm{O}$ narrador sente-se desconfortável com os termos que usa.

Pensando na prosa de Beckett como um todo, vemos que a questão do impasse vai tomando novos contornos na medida em que a obra avança. Se o narrador em primeira-pessoa atravancava sua história através das falhas de memória e das dúvidas em relação ao que dizia, o narrador aqui expõe sua desconfiança através de novas formas. Sua observação aparentemente distanciada é profundamente marcada pela comprovação da incongruência entre a palavra e o que se espera representar através dela. Na expressão desta dificuldade, um dos temas da obra, o texto segue tentando configurar o que se passa com a velha senhora.

A narração dos bastidores do ato criativo também está presente - a tentativa de se contar a história dos últimos dias na vida daquela mulher, as imagens que esse esforço evoca, a busca por uma reprodução adequada do que se imagina. Todo esse processo é

${ }^{105}$ Ill Seen Ill Said, p. 451. "A cabana. Sua localização. Cuidado. Ir. A cabana. Ao inexistente centro de um espaço sem forma [...] O que faz uma cabana num lugar desses? O que foi fazer ali? Cuidado. (Mal Visto Mal Dito, p. 38)

${ }_{106}$ Idem, p. 454. "Mas depressa surpreendê-la ali onde ela melhor se presta a isso". (Idem, p. 42) 
penoso para quem narra e esses obstáculos passam a ser a própria matéria do texto ${ }^{107}$.

O manicômio do crânio ao qual o narrador se refere no parágrafo 15 é o centro no qual as imagens, a linguagem e a visão se unem. Conforme apontado por Brian Finney e Susan Brienza, a opção pelo "trabalho da mente" no ato criativo transformada na própria obra é claramente uma constante nesta segunda trilogia beckettiana. No entanto, as obras não se fecham somente sobre este aspecto. Para além da exploração linguística, sua beleza deriva justamente da configuração dada a esse narrar, dos pedaços de história que o narrador tenta coordenar, ainda procurando um sentido para o ato da escrita. Esses textos compõem-se nessa busca. Seu hibridismo também deriva daí. A linguagem de III Seen IIl Said aproxima-se muito de uma linguagem poética, como se estivesse no meio do caminho entre prosa e poesia.

Marjorie Perloff começa seu artigo sobre IIl Seen IIl Said questionando-se: "Como caracterizar esse discurso estranho?"108 Para além da aproximação com aspectos da lírica, ela chama a atenção para uma mistura de vozes e modelos discursivos que aparecem no texto. Citando alguns exemplos dessa mescla de tons, a crítica aponta 0 tom descritivo em certos momentos, próximo da reportagem ("The two zones form a roughly circular whole"). Há também os momentos nos quais a linguagem é altamente lírica, rica

\footnotetext{
${ }^{107}$ No artigo "Still to Worstward Ho: Beckett's prose fiction since The Lost Ones", Brian Finney ressalta essa questão da autorreferência em Mal Vu Mal Dit. Para o autor, esta é uma característica típica de obras pós-modernistas - uma construção fictícia sobre o processo de se fazer ficção. (Finney, Brian. Still to Worstward Ho: Beckett's prose fiction since The Lost Ones. In: Acheson, James \& Arthur, Kateryna. Beckett's Later Fiction and Drama. Texts for Company. London: Macmillan Press, 1987.) Susan Brienza segue um argumento semelhante em seu livro sobre a prosa final de Beckett. Ela salienta que a ficção final do autor é essencialmente sobre o ato de fazer ficção. A questão da exploração da linguagem neste período ganha bastante destaque em seu livro. (Ver Brienza, Susan. Samuel Beckett's New Worlds. Style in Metafiction. Oklahoma: Oklahoma University Press, 1987.)

${ }^{108}$ Ver Perloff, Marjorie. Between Verse and Prose: Beckett and the New Poetry. In:

Critical Inquiry, Vol.9, n. 2. Chicago: University of Chicago Press, dec. 1982
} 
em elipses e inversões ("To the twelve then for want of better the widowed eye"). Há ainda os trechos que ela chama de trava-línguas ("Winter in her winter haunts she wanders") e também as perguntas curtas e diretas espalhadas pela obra ("Who is to blame? Or what? They? The eye? The missing finger? The keeper? The cry? What cry?" $)^{109}$. Para Perloff, a voz narrativa de Ill Seen Ill said busca uma forma para articular o que ela percebe ou imagina $e$ as falhas decorrentes desta tentativa. O hibridismo estaria ligado a essa tentativa de articular. Ela aproxima a linguagem da obra da definição de "ritmo associativo" de Northrop Frye - um tipo de discurso que representa justamente 0 processo de trazer as ideias para a articulação da linguagem e que não se definiria nem como prosa, nem como verso.

A própria escolha para a diagramação desses textos finais parágrafos entremeados por espaços - marca uma especificidade. 0 aspecto visual do texto faz com que o leitor não o associe nem a um texto em prosa, nem a um poema, como se eles reivindicassem outro tipo de denominação, ou se construíssem justamente nesse "entrelugar".

Só sentirá prazer com a leitura aquele que não estiver em busca de linearidade. O leitor precisa estar disposto a entrar no jogo de uma história contada através de imagens e sons não necessariamente concatenados.

${ }^{109}$ Idem, p. 421-2. As traduções dos exemplos citados por Perloff são: "As duas zonas formam um recinto vagamente circular"; "Rumo aos doze portanto o olho viúvo na falta de coisa melhor"; "Inverno ela erra em sua casa no inverno"; "De quem de que a culpa? Delas? Do olho? Do dedo que falta? Da aliança? Do grito? Que grito?" (Mal Visto Mal Dito, respectivamente p. 39, 46, 42, 51) 
Ill Seen Ill Said traz diversas imagens recorrentes no universo beckettiano. O leitor "treinado" em Beckett reconhecerá os jogos de claro e escuro, a presença da morte, o cenário evocando a Irlanda, o personagem solitário em seu abrigo, os poucos objetos significativos que fazem parte do cotidiano dessa protagonista - um álbum, uma cadeira, um baú, uma cama, uma abotoadeira. Assim como já se fez com Company, a menção a dados biográficos também é bastante citada por alguns estudiosos beckettianos no caso desta obra. A mulher retratada costuma ser associada à mãe de Beckett, May. O mesmo nome também é utilizado na peça Footfalls inclusive na forma de seu anagrama, Amy. Entretanto, assim como dito anteriormente, saber de tal fato não constitui uma exigência essencial para que se aprecie a obra. É possível encontrar diversas associações entre a vida de Beckett e suas criações desde seus primeiros contos, assim como é possível fazer com qualquer outro escritor. A biografia escrita por James Knowlson realiza todas essas ligações entre vida e obra ${ }^{110}$.

O que pode chamar a atenção em relação à figura central do texto é a escolha de uma protagonista feminina uma vez que o universo em prosa de Beckett é predominantemente masculino. Comparada com as outras protagonistas beckettianas - presentes apenas em suas peças - Winnie de Happy Days, a boca de Not I, Maddy em All That Fall, Amy em Footfalls, a mulher de Rockaby - já se destacou que a senhora de Ill Seen Ill Said é a única cuja dignidade permanece inviolável mesmo após todas as explorações imaginativas do narrador ${ }^{111}$. De fato, há uma notável solenidade em torno desta figura, talvez menos pela inspiração na mãe e mais pelo

\footnotetext{
110 Ver Knowlson, J., op. cit.

111 No artigo "Homage to the Dark Lady. Ill seen Ill said", Lawrence Graver ressalta a nobreza com que a mulher desta obra é retratada. Comparando-a com outras protagonistas beckettianas o crítico ressalta que ela é a única que não possui um aspecto cômico ou uma marca de incompletude e fragilidade aparentes. Sua dureza e magnitude trazem uma seriedade para sua figura não encontrada em nenhuma outra protagonista de Beckett. (Graver, Lawrence. Homage to the Dark Lady. III seen Ill Said. In: Ben-Zvi, Linda (Ed.) Women in Beckett: performance and critical perspectives. Illinois: University of Illinois Press, 1992.)
} 
fato dela estar vivendo seus últimos dias, ou seja, ela está muito próxima de alcançar o fim tão almejado pelos personagens beckettianos.

Ainda que a escolha de Beckett tenha sido a de uma protagonista feminina, o texto a insere na mesma linhagem de todos os outros protagonistas de sua prosa. Em determinado momento, a mulher se cobre com um casaco masculino preto. Ao olhar seu refúgio mais de perto, o narrador salienta que a cortina da janela também é um casaco masculino preto: "Under on closer inspection a long greatcoat. A man's by the buttons. The buttonholes. Eyes closed does she sees him?" [...] "The curtain. Seen closer thanks to his hiatus it reveals itself a last for what it is. A black greatcoat"112.

Apesar da interpretação mais lógica de que o casaco seria do marido - afinal ela se dirige frequentemente a uma espécie de túmulo, dando a entender que houve a perda de um ente querido - a vestimenta também pode simbolizar o próprio pertencimento da mulher a esta linhagem. Sua situação é muito parecida com a de outros personagens. Em alguns momentos, a idosa isolada em sua casa lembra o protagonista de Solo, a mulher de Rockaby e também o personagem central de Film - sujeito que não quer ser observado nem pelas pessoas, nem pelos animais de sua casa, além de fugir da própria câmera, também representação de um olhar ${ }^{113}$.

\footnotetext{
112 Ill Seen Ill Said, parágrafos 40 e 45, p. 464 e 467. "Examinada de mais perto é um grande casaco. De homem segundo o abotoamento. Com os olhos fechados ela o vê?"; "A cortina. Examinada de mais perto aproveitando esse tempo morto ela acaba revelando o que é. Um casaco preto semelhante àquele surpreendido fazendo as vezes de coberta". (Mal Visto Mal Dito, op. cit., p. 58 e 61)

${ }_{113}$ A respeito da semelhança entre a protagonista de Ill Seen IIl Said e a de Rockaby, mais uma vez apontando para a proximidade entre prosa e drama, vale a pena mencionar que, em um dos rascunhos iniciais de Mal Vu Mal Dit, há a referência a uma cadeira de balanço na qual a mulher se senta. Beckett a substitui por uma cadeira comum na versão publicada, provavelmente para evitar uma semelhança tão explícita. (A referência à cadeira de balanço pode ser encontrada no manuscrito MS 2206 dos arquivos de Beckett na Universidade de Reading, exatamente no primeiro parágrafo da obra)
} 
As semelhanças com Film não param por aí. A presença do olhar também é marcante no curta-metragem. O homem interpretado por Buster Keaton passa todo o tempo escapando de qualquer tipo de olhar, esgueirando-se pelas paredes e escondendo-se para não ser visto $^{114}$. O roteiro escrito por Beckett inicia-se com a frase do Bispo de Berkeley - Esse est percipi (Ser é ser percebido) - situação que o protagonista tenta evitar a qualquer custo. Além da questão da percepção, o filme de 1964 adianta um tema que se tornará fundamental em uma obra como Ill Seen IIl Said - o papel do olhar, da observação.

O olho também tem uma função narrativa, é uma segunda instância observadora sujeita ao narrador, já que este último também narra as atividades do olho. Podemos apontar aqui um sistema parecido com o de Company. Nesse recuo do narrador da prosa final para o interior da mente, a narração ocorre em uma espécie de cadeia. A desconfiança multiplica as instâncias narrativas. Se em Company há a referência ao criador na própria obra, aqui a narração é dividida com o olho.

O objetivo do olho é apreender as imagens da mulher. É como se ele fosse um órgão personificado que age e reage como um personagem qualquer da história. Essa impressão se confirma logo em sua primeira aparição: "The eye glued to one or the other window has nothing but black drapes for its pains. Motionless against the door he listens long. No sound. Knocks. No answer. Watches all night in vain for the least glimmer. Returns at last to his own and avows, No one. ${ }^{115}$ Sua tarefa é perseguir incansavelmente as imagens. Mais adiante, o olho ainda se encherá de lágrimas, se desesperará, se apressará para captar a cena, tentará se fechar, ou seja, todas as

\footnotetext{
${ }^{114}$ Ver Film (1965), roteiro Beckett, dir. Alan Schneider.

${ }^{115}$ Ill Seen IIl Said, p. 453. "O olho colado numa e noutra janela só vê cortinas pretas. Demoradamente imóvel contra a porta ele escuta. Nada. Bate. Ninguém. Espreita em vão à noite o menor lampejo. Volta enfim para sua terra e confessa, Ninguém". (Mal Visto Mal Dito, op. cit., p. 40-1)
} 
suas ações correm paralelas às cenas envolvendo a mulher e ambas são de igual importância no contexto da obra. Ele é o vigia da mulher, assim como a câmera é o vigia do protagonista de Film. Na tentativa de apanhar as cenas, sua ação oscila entre uma aparente serenidade e a aflição, o pânico.

Várias imagens na obra são associadas ao campo da visão - as janelas das quais se tenta ver a mulher, as cortinas que se abrem e fecham, as duas claraboias que nos remetem ao papel desempenhado pelos olhos. Aparecer e desaparecer são duas constantes no texto. Nesse sentido, é significativo o início do parágrafo 17, no qual um muro sobe repentinamente entre as sombras, atrapalhando a visão da cena que se apresenta ao olho:

Next to emerge from the shadows an inner wall. Only slowly to dissolve in favour of a single space. East the bed. West the chair. A place divided by her use of it alone. How more desirable in every way an interior of a piece. The eye breathes again but not for long. For slowly it emerges again. Rises from the floor and slowly up to lose itself in the gloom ${ }^{116}$.

As imagens se formam e se dissipam sem que o narrador as controle. No parágrafo 11, após uma das desaparições da mulher, o narrador diz: "But she can gone at any time. From one moment of the year to the next suddenly no longer there. No longer anywhere to be seen. Nor by the eye of flesh nor by the other"117. Além dos olhos de carne, há também os olhos que funcionam por trás deles - os

\footnotetext{
${ }^{116}$ Idem, p. 456. "Emerge em seguida da sombra uma parede interposta. Para aos poucos desaparecer em prol de um espaço contínuo. A leste o leito. A oeste a cadeira. Lugar portanto só dividido pelo uso que ela faz dele. Quão mais preferível em todos os sentidos um interior de um só cômodo. Aliviado o olho respira mas não por muito tempo. Pois lentamente a parede se recompõe. Lentamente sai do chão e sobe para se perder na sombra" (Mal Visto Mal Dito, op. cit., p. 45-6).

${ }^{117}$ Ibidem, p.43 "De qualquer momento do ano a outro ela pode não mais estar ali. Subitamente não mais em lugar algum para ver. Nem com o olho de carne nem com o outro" (Mal Visto Mal Dito, p. 43)
} 
olhos responsáveis pela imaginação ${ }^{118}$. A imaginação é a fonte de origem mais poderosa do texto. A narração constantemente chama a atenção a ela, enfatizando que o quê o olho vê não é externo. A mulher não está "à vista" e sim na imaginação de quem narra, o processo é totalmente interior e subjetivo, como aponta o final do sétimo parágrafo: "But little by little she began to appear. Within her walls. Darkly. Time truth to tell still current. Though she within them no more. This long time"119

Captar a imagem e transformá-la em linguagem é o objetivo principal do texto. É no desenvolvimento dessas duas linhas que III Seen IIl Said transcorre. O propósito buscado traz mais uma vez a marca da falha, tão comum no universo beckettiano. As tentativas do olho são intensas, assim como seus momentos de desespero diante da fugacidade das imagens. Nada é nítido a ele. O narrador também tateia no escuro. Sob este aspecto, gostaria de chamar a atenção para o parágrafo 46 da obra, no qual a bruma toma conta do espaço e, consequentemente, da narração:

\begin{abstract}
She is vanishing. With the rest. The already ill seen bedimmed and ill seen again annulled. The mind betrays the treacherous eyes and the treacherous word their treacheries. Haze sole certitude. The same that reigns beyond the pastures. It gains them already. It will gain the zone of stones. Then the dwelling through all its chinks. The eye will close in vain. To see but haze. Not even. Be itself but haze. How can it ever be said? Quick how ever ill said before it submerges all. Light. In one treacherous word. Dazzling haze. Light in its might at last. Where no more to be seen. To be said. Gently gently ${ }^{120}$.
\end{abstract}

\footnotetext{
$118 \mathrm{Na}$ biografia do autor, James Knowlson comenta que na época de escrita de Mal Vu Mal Dit Beckett estava relendo O Rei Lear, de Shakespeare, e também O Livro de Jó. Ele associa os termos usados por Beckett para se referir ao olho a essas obras. O "olho de carne" ecoaria o texto bíblico e a "vil geleia", termo que surge no parágrafo 51, seria uma alusão ao olho de Gloucester, em O Rei Lear. (Knowlson, J., op.cit., )

${ }^{119}$ Ill Seen IIl Said, p. 454. "Mas pouco a pouco ela começou a aparecer ali. Obscuramente. Na verdade esse tempo ainda perdura. Embora ela já não esteja ali. Há muito tempo". (Mal Visto Mal Dito, op. cit., p. 41)

120 Idem, p. 466. "Ela se perde. Com o resto. O já mal visto se ameniza ou mal revisto se anula. A cabeça trai os traidores olhos e a traidora palavra suas traições. Única certeza a bruma. Aquela de além dos campos. Ela já os ganha. Ganhará o pedregal. Em seguida o refúgio por todas as suas frestas. Por mais que o olho se
} 
A imagem da mulher esvai-se e a bruma começa a avançar. 0 trecho enfatiza a visão anuviada, sem clareza, "por mais que o olho se feche", ou seja, por mais que tente imaginar. Essa capacidade de dispersão da imagem radicaliza-se e atinge o próprio olho observador, também transformado em bruma. Nesta passagem, a dificuldade em apreender alia-se à dificuldade em dizer, uma vez que a palavra é considerada traidora. No entanto, as imagens nunca deixam de surgir, impelindo o narrador a continuar. A "bruma luz", a "grande enfim" pode ser associada à morte, a um momento de estagnação das imagens, ao silêncio.

O primado da imagem, já ressaltado em Company, continua aqui. A diferença é que em IIl Seen IIl Said há comentários diretamente relacionados à dificuldade de se representar a imagem em palavras. Além dos pedidos de "calma", "atenção" e "cuidado", o texto é repleto de perguntas, que geralmente surgem no final dos parágrafos. Elas desvelam as dúvidas a respeito do que acabou de ser dito e também reflexões do narrador - "O que faz uma cabana num lugar desses? O que foi fazer ali?; E o homem? Livre dele enfim totalmente?; De quem de que a culpa?; Com os olhos fechados ela o vê?"121 Há também as perguntas que retomam o próprio título da obra - "Como dizer? Como mal dizer?"122.

O mal dizer simboliza a tentativa de corromper uma linguagem já falha, na busca de transformá-la. Sobre esse assunto, é interessante mencionar o que Alain Badiou diz a respeito do processo pelo qual passa a linguagem em Mal Vu Mal Dit. Para o filósofo

feche. Ele só verá bruma. Nem mesmo. Ele próprio não será senão bruma. Como dizê-la. Depressa como mal dizê-la antes que submerja tudo. Luz. Numa traidora palavra. Bruma luz. A grande enfim. Onde nada mais para ver. Para dizer. Calma (Idem, p. 61)

${ }^{121}$ As perguntas aparecem respectivamente nos parágrafos 2, 3, 29 e 40.

122 Refiro-me aqui à Mal Vu Mal Dit que, neste momento, retoma mais claramente seu próprio título: "Comment dire? Comment mal dire?"(Beckett, S. Mal Vu Mal Dit. Paris: Les Éditions de Minuit, 1981, p. 20) Em inglês, ver parágrafo 11: "What is the word? What the wrong word?"( IIl Seen IIl Said, p. 455) 
francês, o "mal dizer" seria uma composição poética realizada a partir do "mal ver", sendo este último representativo de algo que está fora dos padrões comuns da visibilidade. Beckett teria criado uma nova linguagem para representar essa outra forma de "ver", fora das leis já estabelecidas pelo uso comum, aproximando-se assim de uma linguagem poética ${ }^{123}$.

Como já se observa em uma primeira leitura, a linguagem utilizada por Beckett nesta segunda trilogia é bastante diferente daquela empregada nas fases anteriores. Nesta etapa parece haver uma preocupação maior com a sonoridade, a música que emana do texto. Destacamos alguns trechos de Company para exemplificar essa característica. Em Ill Seen IIl Said, os jogos sonoros também estão presentes. É só atentarmos para a frase de abertura do texto - "From where she lies she sees Venus rise" - repleta de aliterações ou ainda para outros exemplos como "The mind betrays the treacherous eyes and the treacherous word their treacheries"124, "On centennial leave from where tears freeze"125. Há também o uso freqüente da repetição, o que transforma algumas frases em uma espécie de refrão que se alterna ao longo da obra - "As she had the misfortune to be still of this world", "Especially at night when the skies are clear", "When not evening night".

As frases recorrentes também chamam a atenção para a ambientação noturna do texto. Antes de dar-lhe o título de Mal Vu Mal Dit, Beckett trabalhou na obra chamando-a de "Soir et nuit". Outros títulos ainda foram considerados pelo autor, como "Mal Vu et Dit", "Brume", "C'est le soir", "Ombres", "Soit soir soit nuit",

123 Ver Badiou, Alain. L'événement et son nom. In: Beckett. L'incrévable désir. Paris: Hachette, 1995.

124 IIl Seen Ill Said, p. 466. "De seu leito ela vê se levantar Vênus"; "A cabeça trai os traidores olhos e a traidora palavra suas traições". (Mal Visto Mal Dito, op. cit., p. 37 e 61)

${ }_{125}$ Idem, p.458. "Afastado há séculos de onde gelam as lágrimas". (Mal Visto Mal Dito, op. cit., 48) 
"Traces"126. Na escolha do título final, a questão da representação, do "mal dizer" a linguagem, prevaleceu sobre o cenário em que se passa a história. No entanto, "tarde e noite" são palavras essenciais para estabelecer o clima da obra, de ocaso, finitude. Há diversas referências à Lua, às estrelas, ao entardecer. Apesar da obra se abrir com o aparecimento de Vênus, astro associado ao dia, o que se ressalta neste início é o desconforto que a mulher sente pela manhã, vingando-se de Vênus quando a noite chega.

Aliado ao ambiente noturno está o próprio vestuário utilizado por ela, sempre roupas negras, assim como as cortinas da casa e sua coberta. Mencionamos anteriormente o jogo de claro/escuro presente na obra, algo marcante também em Company. Há uma cena em que a mulher caminha na neve sem ser atingida por nenhum floco, mantendo-se segundo o texto "imaculadamente negra"127. O trecho nos remete à caminhada citada no parágrafo 38 de Company. Ali a voz dirige-se ao personagem para lembrá-lo de que estava nevando na última vez em que ele saiu de casa. Ela também ressalta o contraste entre a neve e o aspecto sombrio do personagem: "By the time you open your eyes your feet have disappeared and the skirts of your greatcoat come to rest on the surface of the snow. The dark scene seems lit from below" ${ }^{128}$.

Já vimos que a utilização da luz é um aspecto essencial nesses três textos. James Knowlson possui um estudo sobre a presença da luz e da escuridão no teatro de Beckett. Em determinado momento, ele associa a escuridão ao silêncio almejado pelos personagens beckettianos, ou seja, ele faz uma relação entre a escuridão e a situação de fim, de imobilidade total. No entanto, Knowlson ressalta

\footnotetext{
126 Os possíveis títulos estão nos manuscritos MS 2203, MS 2207/1 e MS 2207/2 dos arquivos de Beckett em Reading.

${ }^{127}$ IIl seen IIl said, p. 461.

${ }^{128}$ Company, p. 438-9. "Quando você abre os olhos seus pés desapareceram e as abas do sobretudo repousam na superfície da neve. A cena escura parece iluminada de baixo". (Companhia, op. cit., p. 45)
} 
que este fim é tanto desejado como temido, uma vez que também significaria uma impossibilidade de se continuar criando e narrando, algo que não ocorre na obra beckettiana ${ }^{129}$. Nesta prosa final, parece haver uma relação ainda mais forte entre luz/vida e escuridão/morte, pensando especificamente em Company e III Seen III Said. Tanto o sujeito deitado no escuro como a mulher estão muito próximos de situações-limite, numa espécie de limiar entre vida e morte. Não é à toa que a voz é acompanhada de luz para trazer ao sujeito de Company suas supostas lembranças de vida. Ele está sozinho no escuro. Em III Seen III Said, o contraste entre branco e preto faz parte não apenas da própria figura da protagonista, como também de seu entorno. Os dois textos também trazem o tema do tempo estagnado, recorrente na obra de Beckett.

Em Ill seen Ill said, assim como em Company, há um trecho descrevendo o funcionamento de um relógio:

Close up of a dial. Nothing else. White disc divided in minutes. Unless it be in seconds. Sixty black dots. No figure. One hand only. Finest of fine black darts. It advances by fits and starts. No tick. Leaps from dot to dot with so lightning a leap that but for its new position it had not stirred. Whole nights may pass as may but a fraction of a second or any intermediate lapse of time soever before it flings itself from one degree to the next ${ }^{130 " .}$.

Além de marcar a passagem do tempo, o destaque dado ao relógio também traz mais uma demonstração da fixação do homem

129 O livro de Knowlson é de 1972 e trata, portanto, da obra beckettiana até essa data. Seu estudo baseia-se em romances como Murphy e peças como Krapp's Last Tape, Happy Days, Fin de partie e Play. (Ver Knowlson, James. Light and darkness in the Theatre of Samuel Beckett. London: Turret Books, 1972, p. 33-5.)

130 Ill Seen Ill Said, p. 465. "Primeiro plano de um quadrante. Nada mais. Disco branco dividido em minutos. A menos que seja em segundos. Sessenta pontos pretos. Nenhum número. Uma única agulha. Fina flechinha preta. Ela avança sem tique-taque aos solavancos. Lança-se de um grau ao seguinte com um salto tão instantâneo que só seu novo lugar indica que mudou. Pode passar noites inteiras como apenas uma fração de segundo ou qualquer fração intermediária antes de se precipitar de um ponto a outro. (Mal Visto Mal Dito, p. 60) 
beckettiano pela contagem, pela enumeração. Essa obsessão fica mais evidente em Company, uma vez que nessa obra acompanhamos em detalhes a movimentação dos ponteiros e a sombra que esse movimento causa no mostrador do relógio:

Numb with the woes of your kind you raise none the less your head from off your hand and open your eyes. You turn on without moving from your place the light above you. Your eyes light on the watch lying beneath it [..] At 60 seconds and 30 seconds shadow hidden by hand. From 60 to 30 shadow precedes hand at a distance increasing from zero at 60 to maximum at 15 and thence decreasing to new zero at 30 . From 30 to 60 shadow follows hand at a distance increasing from zero at 30 to maximum at 45 and thence decreasing to to new zero at 60.[.. $]^{131}$

Momentos como esse trazem certa ordem e precisão em um universo marcado pela incerteza, como se o narrador quisesse se agarrar a algo. No entanto, a obsessão rapidamente se dispersa e voltamos ao universo atemporal da obra. O trecho nos remete a outros momentos da prosa beckettiana nos quais acompanhamos em detalhes uma espécie de fixação por cálculos, o que muitas vezes gera um efeito cômico. Podemos citar o episódio em que Molloy cria um método para chupar as dezesseis pedras que carrega consigo:

Je les distribuai avec équite entre mes quatres poches et je les suçais à tour de rôle. Cela posait um problème que je résolus d'abord de la façon suivante. J'avais mettons seize pierres, dont quatre dans chacune de mes quatres poches qui étaient les deux poches de mon pantalon et les deux poches de mon manteau. Prenant une pierre dans la poche droite de mon manteau, et la mettant dans ma bouche, je la remplaçait dans la poche droite de mon manteau par une pierre

131 Company, p. 448. "Entorpecido pelas desgraças de sua espécie você levanta todavia a cabeça das mãos e abre os olhos. Você acende sem se mexer do lugar a luz acima de sua cabeça. Seus olhos pousam no relógio embaixo deles. Mas em vez de ler a hora da noite eles seguem as rotações do ponteiro de segundos ora seguido ora precedido pela sua sombra. Horas depois parece a você o seguinte. Aos 60 segundos e aos 30 segundos a sombra fica escondida pelo ponteiro. De 60 a 30 a sombra precede o ponteiro a uma distância crescente de zero em 60 à máxima em 15 e daí decresce até novo zero em 30. De 30 a 60 a sombra segue o ponteiro a uma distância crescente de zero em 30 à máxima em 45 e daí decresce até novo zero em 60" (Companhia, p. 59) 
de la poche droite de mon pantalon, que je remplaçais par une pierre de la poche gauche de mon pantalon, que je remplaçais par une pierre de la poche gauche de mon manteau, que je remplaçais par la pierre qui était dans ma bouche, dès que j'avais fini de la sucer ${ }^{132}$.

A descrição de todas as possíveis combinações segue por mais 5 páginas até que, finalmente, Molloy decide "mandar as pedras pelos ares", fica com apenas uma e retoma sua narrativa.

Em sua análise de Company, Wayne Booth considera o parágrafo correspondente à movimentação do relógio um momento tedioso da narrativa, uma falha da obra, responsável por desconectar o leitor ${ }^{133}$. Assim como o trecho das pedras em Molloy, esses momentos trazem uma espécie de suspensão da leitura, levando o leitor a se conectar com outro tipo de discurso, o dos cálculos e das combinações. Essa obsessão sempre acompanhou os narradores beckettianos. O trecho se insere dentro desse contexto mais amplo. Pensando apenas em Company, podemos associar a observação minuciosa dos ponteiros a uma reflexão sobre a própria passagem do tempo trazida pelas incursões da voz. As supostas memórias do ouvinte vão da infância à velhice, abrangendo toda uma trajetória de vida $^{134}$.

\footnotetext{
132 Beckett, S. Molloy. Paris: Les Éditions de Minuit, 1982. "Eu as distribuí com equidade entre os meus quatro bolsos e as chupava uma de cada vez. Isso colocava um problema que primeiro resolvi da seguinte forma. Tinha digamos dezesseis pedras, donde quatro em cada um dos meus quatro bolsos, que eram os dois bolsos das minhas calças e os dois bolsos do meu casaco. Pegando uma pedra do bolso direito do meu casaco, e metendo-a na boca, eu a substituía no bolso direito do meu casaco por uma pedra do bolso direito das minhas calças, que substituía por uma pedra do bolso esquerdo das minhas calças, que substituía por uma pedra do bolso esquerdo do meu casaco, que substituía pela pedra que estava na minha boca, logo que tivesse terminado de chupá-la". (Beckett, S. Molloy. Trad. Ana Helena Souza. São Paulo: 2007, p. 101-2)

133 Booth, Wayne. Beckett's Company as Example. In: The Rhetoric of Fiction (second edition). Chicago: The University of Chicago Press, 1983, p. 451-2.

${ }^{134}$ As reflexões em torno da passagem do relógio em Company foram pensadas a partir de questões sobre o mesmo trecho, levantadas por Ana Helena Souza no I Colóquio do Grupo de Estudos Samuel Beckett. (outubro de 2013, SP, FFLCH-USP)
} 
Em IIl seen Ill said os ponteiros saltam de um ponto a outro, às vezes ficam parados, o que acaba por colocar em suspenso a própria marcação desse tempo. O tempo em suspenso é uma marca típica do autor, característica facilmente observada em peças como En attendant Godot, Fin de partie, e também na circularidade de um romance como Molloy, no tempo infernal da máquina de palavras a que está sujeito o personagem de L'innommable e mesmo no cilindro habitado pelos personagens de Le dépeupleur.

Em um ensaio sobre Ill Seen IIl Said, Monique Nagem chama a atenção para o caráter marcadamente circular dessa obra, destacando inclusive a vasta presença de palavras escritas com a letra $o$. A letra está tanto na característica preposição on do texto como também em moon, gloom, door, roof, floor, spoon, too soon, ballon, buttonhook, entre muitas outras. A autora reúne uma série de exemplos para mostrar que a imagem do círculo é essencial nessa obra, tanto no nível verbal como no da própria narrativa. Nagem ainda lembra que os limites do terreno por onde a mulher caminha também são definidos por um círculo, da mesma forma que muitos de seus objetos são redondos. Isso sem falar na forma arredondada do olho e no próprio relógio ${ }^{135}$. A autora ressalta a recorrência do tema da circularidade na obra beckettiana, presente inclusive na escolha das próprias palavras que compõem o texto. Aqui, apesar de evocar uma passagem temporal suscitada pela imagem do relógio, 0 que se tem é um funcionamento "torto" desse mecanismo. Não há uma progressão temporal aparente nas cenas envolvendo a mulher. Ela some e desaparece como se estivesse presa àquele universo e só pudesse ser observada daquela forma, assim como as pedras, os astros, os animais ${ }^{136}$.

135 Nagem, Monique. Know Happiness: Irony in Ill Seen Ill Said. In: Davis, Robin J \& Butler, Lance St. J. Make sense who may. Essays on Samuel Beckett's Later Works. Totowa, New Jersey: Barnes \& Noble Books, 1989, p. 80-1.

${ }^{136}$ Vale mencionar que Beckett começou a escrever o texto no passado, passando-o inteiramente para o tempo presente antes de publicá-lo. A sensação de algo que 
A paralisia temporal também pode ser observada em algumas expressões de movimento que se anulam - "She still without stopping. On her way without starting. Gone without going. Back without returning"137. Tais trechos tanto provocam a sensação de impasse como a de um curto-circuito no desejo de apreensão da imagem.

Em alguns momentos as cenas narradas passam a impressão de estarmos diante de um quadro, de uma pintura que se utiliza intensamente do contraste entre o claro e o escuro. O detalhismo na descrição de algumas imagens da mulher faz com que o leitor tenha uma visão pictórica do que é narrado, como por exemplo no final do segundo parágrafo:

Chalkstones of striking effet in the light of the moon. Let it be in opposition when the skies are clear. Quick then still under the spell of Venus quick to the other window to see the other marvel rise. How wither and wither as it climbs it whitens more and more the stones. Rigid with face and hands against the pane she stands and marvels long ${ }^{138}$.

Temos a mesma impressão de sua figura de costas:

Seated on the stones she is seen from behind. From the waist up. Trunk black rectangle. Nape under frill or black lace. White half halo

acontece naquele momento e que sempre ocorrerá assim, sem progressão, parece ter sido buscada intencionalmente. (Ver Krance, Charles. Introduction. In: Samuel Beckett's Mal Vu Mal Dit/ IIl Seen IIl Said. A Bilingual Evolutionary and Synoptic Variorum Edition. New York and London: Garland Publishing, Inc., 1996)

137 IIl Seen IIl Said, p. 456, par.14. "Ela paralisada sem parar. A caminho sem caminhar. Indo sem ir embora. Sem voltar de volta". (Mal Visto Mal Dito, op. cit., p. 44)

138 Idem, p. 452, par.2. "Pedras gredosas de um efeito impressionante sob a lua. Supondo que ela esteja com céu claro em oposição. Depressa então a velha mal feita do ocaso de Vênus depressa para a outra janela ver surgir a outra maravilha. Como cada vez mais branca à medida que se levanta ela embranquece as pedras cada vez mais. Rígida de pé rosto e mãos apoiados contra a vidraça demoradamente ela se maravilha". (Idem, p. 38) 
of hair. Face to the north. The tomb. Eyes on the horizon perhaps. Or closed to see the headstone" ${ }^{\prime 139}$.

Sobre a relação da obra com as artes plásticas há um artigo muito interessante de David Read comparando algumas imagens de Ill Seen IIl Said aos desenhos e pinturas de Avigdor Arikha. Como sabemos, o artista israelense era um grande amigo de Beckett tendo inclusive ilustrado algumas edições de trabalhos do autor.

Segundo Read, alguns trechos da obra, como por exemplo a imagem da abotoadeira no parágrafo 13 - "the buttonhook larger than life [...] It trembles faintly without cease"140 - e do casaco preto pendurado no parágrafo 45 - "A black greatcoat. Hooked by its tails from the rod it hangs sprawling inside out like a carcass in a butcher's stall"141 - assemelham-se às gravuras "Coat" e "Stick" desenhadas pelo artista para uma publicação de Au Loin un Oiseau (1973), ficção breve de Beckett. Para Read, Arikha retrata esses objetos em sua instabilidade, assim como faz o "olho de carne" de IIl Seen IIl Said:

Viewed from an appropriate distance, the paintings confront one with a recognizable fragment of the real world, just as in Beckett's work the eye of flesh strives to present a clear image of reality. But, in both cases, closer inspection reveals the essential instability of apparently solid objects ${ }^{142}$.

\footnotetext{
139 Ibidem, p. 459, par.26. "Sentada sobre as pedras ela é vista de costas. A partir da bacia. O tronco retângulo preto. A nuca sob o babado da renda preta. O branco seminimbo dos cabelos. Face para o norte. Para a tumba. Ela fita o horizonte talvez. Ou com os olhos fechados vê a pedra. (Ibidem, p. 50)

140 III Seen IIl Said, p. 455. " ... eis maior que o natural a abotoadeira...mal oscila sem cessar" ( Mal Visto Mal Dito, op. cit., p. 43)

${ }^{141}$ Idem, p. 466. " Um casaco preto semelhante àquele surpreendido fazendo as vezes de coberta. Preso no trilho de cabeça para baixo ele se desfralda do lado avesso tal qual a carcaça no talho". (Idem, p. 61)

142 Read, David. Beckett's Search for Unseeable and Unmakeable: Company and III Seen IIl Said. In: Modern Fiction Studies, Vol. 29, n.1, Spring 1983, p. 116. "Vistas de uma distância apropriada, as pinturas nos confrontam com um fragmento reconhecível do mundo real, assim como o "olho de carne" na obra de Beckett se esforça para apresentar uma imagem nítida da realidade. Contudo, em ambos os casos, uma inspeção mais próxima revela a essencial instabilidade de objetos aparentemente sólidos".
} 
A oposição entre branco e preto, escuridão e luminosidade será bastante desenvolvida em IIl Seen IIl Said, o que reforça o apelo imagético da obra. O narrador salienta logo no primeiro parágrafo o contraste entre os cabelos, a face, as mãos brancas da mulher e todo o resto negro. As abundantes pedras do local são brancas, assim como os animais que surgem em seu caminho - cordeiros, ovelhas. Neste jogo de claro/escuro há uma espécie de fusão entre a mulher e o espaço.

O narrador compara constantemente a mulher à pedra, como se ela fosse uma rocha negra no meio daquele universo branco. A comparação tem a ver com a dureza de seu velho corpo - "And the old body itself. When it seems of stone"143. Além de dureza e resistência, a imagem da pedra também sugere imobilidade. Assumir a condição de pedra significaria a fusão total entre a mulher e seu entorno e também o fim de sua existência humana. A associação entre o corpo de um personagem e a pedra aparece ainda em outras obras de Beckett do período, sempre evocando a situação de imobilidade e a proximidade do fim $^{144}$. Além disso, voltando a uma aproximação com as artes plásticas, alguns estudiosos já apontaram como o conhecimento de Beckett sobre esse universo aparece em sua obra. A "qualidade de pedra" também sugere a ideia de uma escultura ${ }^{145}$.

\footnotetext{
${ }^{143}$ IIl Seen IIl Said, p. 459. "E o próprio velho corpo. Quando parece de pedra". (Mal Visto Mal Dito, op. cit., p. 50)

${ }^{144}$ Como por exemplo em Ohio Improptu e Rockaby.

145 Em um capítulo de Samuel Beckett's German Diaries(1936-1937) dedicado às artes plásticas, Mark Nixon menciona a "qualidade de pedra" de algumas figuras beckettianas, comentando as análises que Beckett fez em seus diários sobre certas esculturas eclesiásticas vistas durante a viagem pela Alemanha. Apesar de Nixon ligar essa imagem escultural às posições dos personagens Joe em Eh Joe e da Figura Masculina em Ghost Trio, além de mencionar a rigidez da cena principal de Ohio Improptu, a mesma qualidade também poderia ser apontada na protagonista de IIl Seen IIl Said. (Ver Nixon, Mark. Talking Pictures: Beckett and the Visual Arts. In: Samuel Beckett's German Diaries (1936-1937). London: Continuum, 2011). Vale lembrar que a pedra em si faz parte do universo beckettiano. Molloy carrega pedras no bolso e uma das histórias que Malone se propõe a contar é justamente sobre uma pedra.
} 
Há um grande destaque no texto para o corpo da mulher - seus gestos, movimentos, as expressões de seu rosto. Quando este tema surge ressalta-se sua rigidez, seus movimentos precisos para tomar a sopa, o paralelo entre seu rosto e uma máscara antiga, as mãos que se apertam e soltam em movimentos de sístole e diástole, atividade cara a Beckett e já mencionada em outros de seus textos. As relações feitas nessas descrições acabam por trazer o tema da morte, aproximando-a da protagonista. A máscara antiga é comparada ao rosto dos mortos, os movimentos das mãos ao "ritmo de um coração que pena"146. A proximidade da morte é ainda reforçada pelos momentos nos quais as doze figuras aparecem circundando a mulher. A cena tem um aspecto sombrio e ao mesmo tempo solene. Eles tanto a observam como parecem anunciar algo, prepará-la para algo, como se cumprissem uma espécie de ritual no qual ela está incluída sem saber $^{147}$.

Se "imaginar" é o mote de Company, "observar" é o mote de III Seen IIl Said. É o que fazem os doze que a circundam, é o que ela faz na janela, é a tarefa incessante do olho, é o que faz o narrador em relação ao olho, e, em última instância, o próprio leitor.

A tensão gerada pelo esforço em apanhar as cenas é crescente no decorrer da obra e se alivia nos parágrafos finais. Após um aparente sumiço das imagens o narrador se despede e experimenta

\footnotetext{
${ }^{146}$ Utilizo a expressão retirada da tradução de Eloísa Araújo Ribeiro a partir de Mal Vu Mal Dit - "Rythme d'un coeur qui peine". (Beckett, S. O despovoador. Mal Visto Mal Dito. Trad. Eloísa Araújo Ribeiro. São Paulo: Martins Fontes, 2008, p.51) Em III Seen IIl Said, o trecho guarda o mesmo sentido-"Rhythm of a labouring heart". (III Seen IIl Said, p. 460)

${ }^{147} \mathrm{Em}$ The drama in the text, Enoch Brater interpreta a presença dessas doze figuras, associando-as tanto a um ritual druida do qual Beckett teria conhecimento como aos doze apóstolos católicos. No entanto, ele salienta que o ritual mais importante em III Seen IIl Said seriam "os rituais da escrita, os complexos ritos de ver, dizer e ouvir". (Brater, E. The drama in the text. Beckett's late fiction. New York: Oxford University Press, 1994, p. 124-6). Em um artigo já citado, Brater também fala do uso do ritual nesta obra como uma maneira de chamar a atenção para questões em torno de acessibilidade e comunicação. (Ver Brater, E. Voyelles, Cromlechs and the Special (W) rites of Worstward Ho. In: Acheson, James \& Arthur, Kateryna. Beckett's Later Fiction and Drama. Texts for Company. London: Macmillan Press, 1987).
} 
um raro prazer ao pensar que está diante de um espaço desabitado. Para ele, conhecer a felicidade é aspirar esse vazio. Entretanto, este momento de felicidade se contradiz pela sonoridade das últimas palavras do texto - Know happiness equivale foneticamente a No happiness. Fica implícito no texto que qualquer prazer é momentâneo. As cenas retornarão à sua mente e ele voltará a "mal dizê-las". Se esse trabalho se deu por encerrado em IIl Seen Ill Said, a obra Worstward Ho o trará de volta em uma de suas formas mais radicais.

\subsection{Worstward Ho - Mente incansável}

Try again. Fail again. Fail better.

Add? Never.

De difícil absorção, Worstward Ho é o texto que apresenta mais dificuldades ao leitor desavisado. Aquele que segue a trajetória em prosa de Beckett reconhecerá o radicalismo no tratamento dado a velhas questões, como a busca pelo mínimo e a falência da linguagem aliadas à necessidade de seguir adiante, continuar. $\mathrm{O}$ texto se abre com a familiar preposição on, referência marcante na prosa de Beckett desde L'innommable: "On. Say on. Be said on. Somehow on. Till nohow on. Said nohow on"148. O "seguir em frente" deste começo aponta para mais um esforço do incansável narrador beckettiano, que não se cala nunca.

\footnotetext{
${ }^{148}$ Worstward Ho, p. 471. "Adiante. Dizer adiante. Ser dito adiante. De algum modo adiante. Até que de nenhum modo adiante. Dito de nenhum modo adiante". (Pra frente o pior. In: Companhia e outros textos, op. cit., p. 65)
} 
O título escolhido tanto alude a um romance do século XIX Westward Ho (1855), do romancista inglês Charles Kingsley - como ao grito dos marinheiros Land Ho! - "Terra à vista" ${ }^{149}$. A substituição de west por worst traduz bem o caminho que a obra vai trilhar - o pior avante, rumo ao pior. $O$ entusiasmo presente nas expressões que inspiraram Beckett pode ser lido ironicamente na escolha deste título. O narrador de Worstward Ho se mostra descontente no decorrer da obra, a direção buscada não o satisfaz, sua excitação é gerada pela frustração e não pelo entusiasmo de quem enxerga algo positivo adiante. A terra à vista está arrasada ou em processo de destruição.

Essa busca pelo piorar se dá através de uma série de ataques à linguagem, em um movimento intenso pelo "mal dizer", sempre no sentido de marcar a falha e a insatisfação em relação ao que acabou de ser dito - "Say for be said. Missaid. From now say for be missaid"150 - diz o segundo parágrafo da obra.

Na tentativa de sempre piorar o que diz - objetivo do texto - o narrador submete as palavras a um verdadeiro colapso. Em diversos momentos, o leitor chega a se perder entrando em uma espécie de vertigem lingüística provocada pela repetição de palavras articuladas e rearticuladas ao seu limite e também pela sonoridade encantatória, como neste exemplo: "So leastward on. So long as dim still. Dim undimmed. Or dimmed to dimmer still. To dimmost dim. Leastmost in dimmost dim. Utmost dim. Leastmost in utmost dim. Unworsenable worst." ${ }^{151}$

\footnotetext{
${ }^{149}$ Além dessas referências, Enoch Brater também aponta relações do título com algumas citações das peças King Lear, Othelo e Twelfth Night, de Shakespeare. Nesta última peça mencionada, por exemplo, a coragem da protagonista Viola "Westward Ho" é ressaltada. Brater ainda menciona uma peça renascentista chamada Westward Hoe (1607), de Webster e Dekker. (Brater, E. The drama in the text, p. 137.)

${ }^{150}$ Worstward Ho, p. 471. "Dizer por ser dito. Dito mal. Desde agora dizer por ser dito mal." (Pra frente o pior, op. cit., p. 65)

${ }^{151}$ Worstward Ho, p. 480. "Assim pro mínimo adiante. Até quando ainda penumbra. Penumbra desensombrada. Ou ensombrada para mais sombria ainda. Para a mais
} 
Além do trabalho sonoro, a exploração de um mesmo vocábulo ao extremo, como ocorre acima com as palavras dim e worst é freqüente na obra. No entanto, essa exploração se dá em chave negativa, já que a intenção é alcançar o mínimo valor da palavra, empobrecê-la, desconstruí-la, "descascá-la", propósito antigo do narrador beckettiano.

O interessante é que tal intuito acaba por construir um texto extremamente rico musicalmente que, assim como as duas obras anteriores, parece ganhar mais sentido se lido em voz alta ${ }^{152}$. Worstward Ho é o que mais depende dessa oralidade uma vez que sua construção está muito pautada pelo trabalho com o som. 0 próprio texto solicita a voz através da constante repetição do verbo to say: "Say a body, Say yes, Say no, Say only - ..." Tais trechos tanto incitam o próprio narrador a seguir seu trajeto como o leitor a "dizer" essas palavras.

As dificuldades em se escolher o que dizer também se traduzem nos momentos nos quais o narrador não dá continuidade ao texto, substituindo uma possível palavra por um travessão, como no caso acima. O momento fica em suspenso, a palavra não é encontrada e sim calada. Há também as recorrentes perguntas espalhadas por toda a obra que, como em IIl Seen IIl Said, revelam o caráter incerto do texto, a dúvida constante e o próprio impasse narrativo. O uso da exclamação mostra um narrador completamente envolvido com seu objetivo, expressando todo seu esforço no sentido de piorar o texto: "What room for worse! How almost true they sometimes almost ring!

sombria penumbra. Minimáximo na mais sombria penumbra. Penumbra máxima. Minimáximo na penumbra máxima. Impiorável pior." (Pra frente o pior, op. cit., p. 80)

152 No mesmo capítulo citado anteriormente, Brater comenta que o texto de Worstward Ho deveria ser lido em voz alta e também nos chama a atenção para a exploração das "texturas sonoras da linguagem", ponto alto da obra. (Brater, E. op. cit., p. 139) 
How wanting in inanity!"153 A exclamação ausente no título se faz presente nesses momentos nos quais o narrador expressa sua frustração.

O radicalismo formal é inerente ao próprio conteúdo do texto imagens que também se desconstroem e se transformam diante do narrador. Tanto em Company como em III Seen III Said acompanhamos fragmentos de narrativa, seja através das supostas recordações trazidas pela voz, seja seguindo o cotidiano da senhora. Em Worstward Ho, a experiência de desconstrução narrativa é mais intensa. A história só avança através do movimento de minar não só o que se diz mas também as três imagens que surgem inicialmente ao narrador - um homem visto de costas, um velho de mãos dadas com uma criança e uma cabeça apoiada em duas mãos. As imagens também são "mal vistas", no sentido de que não passam de sombras, estão imersas na mesma obscuridade característica dessas obras finais. A sensação de impasse e aprisionamento volta a ser destacada. Um bom exemplo neste caso seriam os parágrafos $14 \mathrm{e}$ 15 da obra nos quais, na tentativa de descrever o lugar em que se passam as imagens, o narrador cria um espaço sem saída:

A place. Where none. A time when try see. Try say. How small. How vast. How if not boundless bounded. Whence the dim. Not now. Know better now. Unknow better now. Know only no out of. No knowing how know only no out of. Into only. Hence another. Another place where none.

Whither once whence no return. No. No place but the one. None but the one where none. Whence never once in. Somehow in. Beyondless. Thenceless there. Thiterless there. Thenceless thitherless there ${ }^{154}$.

153 Worstward Ho, parágrafo 38, p. 476. "Que espaço para pior! Como quase verdade que elas às vezes quase ecoam!Quão deficientes em inanidade! (Pra frente o pior, op. cit., p.72)

${ }^{154}$ Idem, p. 472-3. "Um lugar. Onde nenhum. Um tempo quando tentar ver. Tentar dizer. Quão pequeno. Quão vasto. Quão senão sem confins confinado. Donde a penumbra. Não agora. Saber melhor agora. Não saber melhor agora. Saber somente não pra fora. Não se sabe como saber somente não pra fora. Pra dentro somente. Daí outro. Outro lugar onde nenhum. Aonde uma vez donde sem retorno. Não. Nenhum lugar exceto o único. Nenhum exceto o único onde nenhum. 
As três imagens vão se alterando, pois o narrador não se satisfaz com elas, questiona o que vê, tenta piorá-las seguindo seu objetivo. A primeira, por exemplo, começa com um conjunto de ossos que o narrador vê se levantar do chão. Antes, ele já havia tentado fixar a imagem desse corpo e do lugar em que o mesmo poderia estar:

Say a body. Where none. No mind. Where none. That at least. A place. Where none. For the body. To be in. Move in. Out of. Back into. No. No out. No back. Only in. Stay in. On in. Still.

All of old. Nothing else ever. Ever tried. Ever failed. No matter. Try again. Fail again. Fail better.

First the body. No. First the place. No. First both. Now either. Now the other. Sick of the either try the other. Sick of it back sick of the either. So on. Somehow on. Till sick of both. Throw up and go. Where neither. Till sick of there. Throw up and back. The body again. Where none. The place again. Where none. Try again. Fail again. Better again. Or better worse. Fail worse again. Still worse again. Till sick for good. Throw up for good. Go for good. Where neither for good. Good and all $^{155}$.

O trecho acima citado corresponde aos parágrafos 3,4 e 5 do texto, ou seja, logo na abertura da obra o que o leitor acompanha é a tentativa do narrador em configurar uma imagem e um local, dar início à sua obra. As frases curtas e as repetições criam a impressão de um texto que avança abruptamente e o ritmo imposto, se fizermos a leitura em voz alta, parece propor uma certa velocidade, fôlego

Donde nunca uma vez dentro. De algum modo dentro. Sem além. Lá sem de lá. Lá sem pra cá. Lá sem de lá sem pra cá". (Pra frente o pior, op. cit., p. 67-8)

155 Worstward Ho, p. 471. "Dizer um corpo. Onde nenhum. Nenhuma mente. Onde nenhuma. Isso pelo menos. Um lugar. Onde nenhum. Para o corpo. Estar nele. Mexer-se nele. Fora dele. De volta a ele. Não. Não fora. Não de volta. Somente nele. Ficar nele. Adiante nele. Parado.

Tudo de outrora. Nada mais nunca. Nunca tentado. Nunca falhado. Não importa. Tentar de novo. Falhar de novo. Falhar melhor.

Primeiro o corpo. Não. Primeiro o lugar. Não. Primeiro os dois. Ora um. Ora o outro. Farto do um tentar o outro. Farto deste de volta farto do um. Assim por diante. De algum modo adiante. Até farto dos dois. Vomitar e ir. Onde nenhum. Até farto de lá. Vomitar e de volta. O corpo de novo. Onde nenhum. O lugar de novo. Onde nenhum. Tentar de novo. Falhar de novo. Melhor de novo. Ou melhor pior. Falhar pior de novo. Ainda pior de novo. Até farto de vez. Vomitar de vez. Ir de vez. Onde nenhum deles de vez. De uma vez por todas" (Pra frente o pior, p. 65-6) 
curto, um fluxo contínuo do pensamento de quem cria algo naquele momento. Ao mesmo tempo em que tenta imaginar um corpo e um espaço para que ele ocupe, o narrador sente-se "farto" dessas imagens, precisa vomitá-las, aliviar-se. Elas não são suficientemente "falhas" em sua visão e isso faz com que ele persista.

O corpo se configurará posteriormente na visão de um homem de costas. Em seguida ele está vestido com um casaco preto e de joelhos. No final da obra, transforma-se em mulher, também de costas e de joelhos. Tanto essa imagem como a do adulto de mãos dadas com a criança são familiares ao universo de Beckett. No final do texto, o narrador vê uma imagem claramente associada à IIl Seen IIl Said: "Nothing and yet a woman. Old and yet old. On unseen knees. Stooped as loving memory some old gravestones stoop. In that old graveyard. Names gone and when to when. Stoop mute over the graves of none"156. É como se todo seu universo ficcional estivesse presente ali surgindo e sumindo a essa mente incansável. Estudiosos como o próprio Brater e também Alain Badiou citam Worstward Ho como um texto que se refere a toda obra anterior do autor. Brater menciona a exploração do vocabulário tipicamente beckettiano que ocorre no texto e Badiou fala, em termos gerais, da obra como "um balanço do conjunto do empreendimento" do pensamento de Beckett ${ }^{157}$. A referência ao vômito, ao sentir-se mal, exemplificam bem essa ideia de um universo que se revolve intensamente na cabeça do narrador e precisa ser expelido. Palavras e imagens reconhecíveis e transformadas habitam o mundo de Worstward Ho. No entanto, a ênfase na imagem da cabeça, do crânio propriamente, é a que terá mais relevância no contexto desta obra.

\footnotetext{
${ }^{156}$ Idem, p. 484. "Nada e todavia uma mulher. Velha e todavia velha. Sobre joelhos invisíveis. Inclinada como saudosa memória algumas lápides velhas se inclinam. Naquele cemitério velho. Nomes se foram e de quando em quando. Inclinada muda sobre os túmulos de ninguém". (Idem, p. 87)

${ }^{157}$ Brater, E., op. cit., e Badiou, A. Ser, existência, pensamento: prosa e conceito. In: Pequeno manual de inestética. São Paulo: Estação Liberdade, 2002.
} 
A imagem da mente já fascinava Beckett desde sua primeira ficção. É famoso o sexto capítulo de Murphy, no qual se descreve justamente o funcionamento da mente deste protagonista:

It is most unfortunate, but the point of this story has been reached where a justification of the expression "Murphy's mind" has to be attempted. [...]

There were the three zones, light, half light, dark, each with its speciality.

In the first were the forms with parallel, a radiant abstract of the dog's life, the elements of physical experience available for a new arrangement. Here the pleasure was reprisal, the pleasure of reversing the physical experience. [...]

In the second were the forms without parallel. Here the pleasure was contemplation. [...]

The third, the dark, was a flux of forms, a perpetual coming together and falling asunder of forms ${ }^{158}$.

Tal exemplo se notabiliza se pensarmos em como a mesma imagem aparece em Worstward Ho. O "narrar de fora" mais distanciado e paródico lentamente caminha para um "narrar de dentro", sombrio e quase desesperado, marcado pela própria tentativa dessa mente em criar e mal dizer o que criou, seguindo a proposta dessa obra.

De toda a minuciosa divisão da mente de Murphy em três zonas com suas respectivas características chegamos ao que restou de um crânio em Worstward Ho - "What where skull to go? As good as go.

\footnotetext{
158 Beckett, S. Murphy, op. cit., p. 67 e 69-70. Na tradução brasileira optou-se pela expressão "espírito de Murphy". "Infelizmente é chegado o momento nesta história em que é preciso tentar justificar a expressão o "espírito de Murphy"[...] Havia três zonas - a claridade, a penumbra, a escuridão, cada uma com sua particularidade. $\mathrm{Na}$ primeira, havia as formas com paralelo, uma síntese radiosa da vida de cachorro, os elementos da experiência física disponíveis para novos arranjos. Aqui, o prazer era ativo, o prazer de reverter a experiência física [...]

$\mathrm{Na}$ segunda, havia as formas sem paralelo. Aqui, o prazer era contemplativo [...] A terceira, a escuridão, era um fluxo de formas, uma perpétua confusão e diferenciação das formas" (Beckett, S. Murphy. Trad. Fábio de Souza Andrade. São Paulo: Cosac Naify, 2013, p. 85 e 88 )
} 
Into what then black whole? From out what then? What why of all? Better worse so? No. Skull better worse. What left of skull"159.

A diferença na abordagem de uma mesma imagem também traduz e reforça a trajetória do narrador beckettiano pelo desnudamento, pelo "cavar buracos na linguagem", expressão bastante apropriada para Worstward Ho, apesar de pronunciada pelo autor quase 50 anos antes da escrita do texto. Não sobra quase nada do crânio retratado aqui. Ele se esfuma juntamente com as palavras. Se em Murphy e na prosa inicial havia uma expansão narrativa, Worstward Ho é o símbolo máximo da retração que acomete estes textos finais. O texto se volta sobre si próprio. Não é a toa que a outra vertente deste período trata do confinamento e das posições humanas no interior dos espaços fechados. Todo o movimento da obra final beckettiana ocorre para dentro, seja do espaço, seja da mente. A retração, entretanto, não significa intimidação narrativa, uma vez que a narração dessas obras explora diversas possibilidades.

Desde a trilogia do pós-guerra, observamos a evolutiva perda de movimento dos protagonistas beckettianos. Da errância característica das novelas em francês para a cama de Malone ou o vaso habitado pelo protagonista de L'innommable há uma notável progressão para a imobilidade corporal. Em contrapartida, as vozes da mente, a capacidade de criar e principalmente, a de imaginar, saltam ao primeiro plano. $O$ foco não está mais naquele narrador que conta sua história e sim, no trabalho da mente que cria. Os personagens são transformados em imagens e, como tais, são passivos, não tomam mais a palavra. O homem deitado em Company não esboça qualquer reação, é apenas o ouvinte, e a mulher de III

${ }^{159}$ Worstward Ho, p. 484. "O quê se o crânio se fosse? Bem dizer se fosse. Pra dentro então de que buraco preto? Pra fora do que então? O quê por quê de tudo? Melhor pior assim? Não. Crânio melhor pior. O que sobrou do crânio". (Pra frente o pior, op. cit., p. 87) 
Seen Ill Said só pode ser observada. A figura do crânio passa a ser a personagem central desta segunda trilogia, especialmente em Worstward Ho. Não há mais um ouvinte a quem o narrador se dirija ou a mulher a quem ele observa. O foco no próprio trabalho da mente fica mais explícito aqui.

Do parágrafo 36 ao 44 o narrador se esforça e se angustia para tentar piorar essas três imagens que vieram se formando desde o início da obra. A partir do parágrafo 45 há uma concentração ainda maior na imagem do crânio: "Next the so-said seat and germ of all. Those hands! That head! That near true ring! Away. Full face from now. No hands. No face. Skull and stare alone. Scene and seer of all"160.

O parágrafo 46 , mais ou menos na metade da obra, representa uma espécie de retomada forçando a continuidade do texto. Ele recupera e transforma a frase de abertura: "On. Stare on. Say on. Be on. Somehow on. Anyhow on [...]"161. No entanto, o destaque a partir deste momento será a figura do crânio com os olhos estatelados. A imagem grotesca e até mesmo assustadora é fruto de um universo que tenta se reduzir ao máximo deixando aparente apenas o "germe de tudo", nas palavras do próprio narrador. O crânio isolado no espaço chama a atenção não só para o seu aspecto físico - o corpo se reduz a um órgão assim como a palavra ao seu mínimo - mas também para sua função, para o que acontece em seu interior, o lugar em que todo pensamento começa ${ }^{162}$. É ali que todas as imagens são formadas e pedem a configuração artística que o narrador tenta

160 Worstward Ho, p. 477. "Próximos os assim ditos sede e germe de tudo. Aquelas mãos! Aquela cabeça! Aquele quase verdadeiro eco! Fora. Rosto todo desde agora. Nenhuma mão. Nenhum rosto. Crânio e olhar fixo só. Espetáculo e espectador de tudo". (Pra frente o pior, op. cit., p. 74)

${ }^{161}$ Idem. "Adiante. Olhar fixo adiante. Dizer adiante. Estar adiante. De algum modo adiante. De qualquer modo adiante". (Idem)

${ }^{162}$ Apesar do destaque dado à imagem do crânio, vale dizer que o narrador o coloca no mesmo patamar das outras imagens - "shades with the other shades" o que parece "piorá-lo" ou mesmo diminuir sua importância. Entretanto sua função se notabiliza justamente porque ele concentra as capacidades de criar, imaginar e se expressar em palavras, temas relevantes para essa prosa final. 
encontrar, buscando tanto o "menos" quanto o pior. Esta empreitada negativa está apontada desde as primeiras linhas da obra nas quais, mais uma vez, o narrador beckettiano tenta criar uma narrativa. A investida, entretanto, traz a marca de um autor que, muitos anos antes, insatisfeito com nossa pobreza linguística, já perseguia uma literatura da despalavra. Worstward Ho, um de seus últimos textos, parece ser a experiência que mais se aproxima deste objetivo.

\section{4. "Falhando melhor". 0 embate com a palavra}

Que voulez-vous, Monsier? C'est les mots; on n'a rien d'autre. ${ }^{163}$

O que está em jogo na fase final da prosa beckettiana é um questionamento sobre os modos $\mathrm{e}$ as possibilidades de representação. Mais que isso, a investigação sobre a própria abolição da representação está em pauta. A idéia de "falhar melhor" traz em si a tentativa de se atingir o grau em que a "obrigação de expressar" seria finalmente vencida. Em Três Diálogos com Georges Duthuit (1949), Beckett defende uma arte que preferiria "a expressão de que não há nada a expressar". Mais precisamente: "a expressão de que não há nada a expressar, nada com que expressar, nada a partir do que expressar, nenhuma possibilidade de expressar, nenhum desejo de expressar, aliado à obrigação de expressar". Nesses diálogos sobre artes plásticas, Beckett acaba expondo o que enfrentava como

163 Resposta de Beckett a Niklaus Gessner ao ser questionado sobre a contradição entre sua escrita e a convicção a respeito da incapacidade de significação da linguagem (A frase é citada no livro de Martin Esslin, The Theatre of Absurd, apud Boxall, Peter (Ed.) Samuel Beckett. Waiting for Godot/Endgame. Cambridge: Icon Books, Ltd., 2000, p. 23). 
escritor $^{164}$. Sua prosa acabou por se construir dando forma a esse impasse. Seu projeto literário pressupunha desde cedo um tipo de arte que deixasse "o caos do mundo entrar". Essa ideia fica mais evidente em sua obra do pós-guerra, por motivos históricos que não poderiam ser negligenciados pelos artistas que vivenciaram esse período. Vimos que Beckett o vivenciou intensamente. A leitura já mencionada de Adorno sobre Fin de partie, vendo a peça como uma resposta à crise da cultura ocidental e à ascensão do capitalismo avançado marca bem a relevância de questões latentes na obra beckettiana do período.

Os clochards de En attendant Godot e também das novelas e primeiros romances são fruto de um mundo que se transforma posteriormente na obra do autor. O homem errante e solitário em busca de abrigo é substituído pelo homem aprisionado, vivo apenas através da observação de um outro. É este "outro", este novo narrador, que ganha destaque na prosa final. Sua capacidade de observação distanciada e ao mesmo tempo afetada pelo que vê ou diz caracterizam essa segunda trilogia. A angústia do narrador das novelas, da trilogia e dos Textes pour rien estava na sua insatisfação com 0 ato de narrar. Vimos que esse tema também está presente aqui, especialmente em Worstward Ho. É uma nova forma de angústia, intensificada pela admissão de que as palavras não são mecanismos confiáveis de representação. Daí o salto para outros recursos - imagéticos, sonoros, visuais - que, entretanto, continuam dependentes da gasta palavra para se concretizarem. É na tentativa de se desvencilhar dela que Beckett produz seus textos mais elaborados.

A carta a Axel Kaun volta a ganhar relevância aqui. Já em 1937, antes da escrita de suas principais obras, Beckett discutia o

\footnotetext{
${ }^{164}$ Ver Andrade, Fábio de Souza. Três Diálogos com Georges Duthuit, op. cit., p.
} 175. 
que considerava uma defasagem da literatura em relação a outras artes:

\begin{abstract}
Ou será que a literatura, solitária, deve permanecer atrasada em seus velhos caminhos preguiçosos que há tanto tempo foram abandonados pela música e pela pintura? Há alguma coisa paralisantemente sagrada na natureza viciosa da palavra que não se encontra nos elementos das outras artes? Há alguma razão pela qual a terrível e arbitrária materialidade da superfície da palavra não seria capaz de ser dissolvida, como pode, por exemplo, a superfície do som, rasgada pelas enormes pausas, da Sétima Sinfonia de Beethoven, de forma que, por páginas a fio, nós não podemos perceber nada a não ser um caminho de sons suspensos nas alturas vertiginosas, ligando insondáveis abismos de silêncio? Uma resposta faz-se necessária. ${ }^{165}$
\end{abstract}

Se pensarmos em Worstward Ho podemos ver que Beckett tentou encontrar essa resposta. A tensão à qual o autor submete cada palavra nessa obra evidencia essa tentativa de romper com sua materialidade, criar novas formas possíveis para seu emprego. No entanto, ao contrário da música e da pintura, a palavra sempre trará algum rastro de significação, tornando a tarefa da literatura mais problemática. Vale lembrar aqui da peça radiofônica Words and Music (1962), na qual Beckett apresenta um confronto entre a música e a palavra, transformando-as em personagens que se manifestam quando solicitadas. Nesta peça, um homem chamado Croak dita temas para que as palavras e a música improvisem e se expressem. Beckett teria dito a Adorno que a peça termina com a vitória inequívoca da música, reforçando mais uma vez sua insatisfação com a linguagem ${ }^{166}$.

Em seu ensaio sobre Proust, décadas antes, o autor diz que "o hábito é o lastro que acorrenta o cão a seu vômito" e que "a devoção

\footnotetext{
${ }^{165}$ Beckett, S. apud Andrade, Fábio de Souza, op. cit., p. 169.

${ }^{166}$ A frase de Beckett a Adorno é citada em um artigo de Jonathan Kalb (Ver Kalb, J. The mediated Quixote: the radio and television plays, and Film. In: Pilling, John (Ed) The Cambridge Companion to Beckett. Cambridge: The Cambridge University Press, 1994, p. 132)
} 
perniciosa ao hábito paralisa nossa atenção"167. As frases estão no contexto de uma análise de Em busca do tempo perdido, no entanto, chamam nossa atenção para uma reflexão do autor sobre as dificuldades em romper padrões. No campo literário, Beckett definitivamente os rompeu. Com sua prosa final, ele reivindica que 0 leitor também abandone seus antigos padrões, sua posição confortável, surpreenda-se com o que lê, busque referências e novas percepções do texto literário. Recorrendo novamente a Adorno, desta vez em um elogio sobre a arte de Paul Valèry, temos: "A obra de arte que exige o máximo de sua própria lógica e coerência, assim como o máximo de concentração de seus receptores é para ele (Valèry) uma analogia do sujeito consciente e mestre de si mesmo, que não capitula"168. A prosa final beckettiana exige essa postura ativa de seus receptores, forçando a uma reflexão constante na medida em que provoca o leitor com sua estranheza, seus enigmas e questionamentos narrativos.

O embate do autor com a palavra e a busca por novas formas de representação atingem seu auge nestes textos finais. A estranheza e as dificuldades que eles apresentam devem-se, a princípio, ao alto experimentalismo que Beckett se permitiu em sua ficção dos anos 80 , entrave para o leitor não familiarizado com o universo do escritor, mas também fonte de instigação e curiosidade para que se realize esse percurso.

${ }^{167}$ Beckett, S. Proust. Trad. Arthur Nestrovski. São Paulo: Cosac Naify, 2003, p. 17 e 19.

${ }^{168}$ Adorno, Th. W. O artista como representante. In: Notas de Literatura I. Trad. Jorge de Almeida. São Paulo: Ed. 34, 2003, p. 163. 


\title{
III - EM BUSCA DE COMPANHIA. "E VOCÊ COMO SEMPRE ESTEVE. SÓ."
}

\author{
Vladimir: É difícil conviver com você, Gogô. \\ Estragon: Seria melhor a gente se separar. \\ Vladimir: Você sempre diz isto. E sempre volta. \\ Samuel Beckett, Esperando Godot. \\ Clov: Por que você não me manda embora? \\ Hamm: Não tenho mais ninguém \\ Clov: Não tenho outro lugar. \\ Samuel Beckett, Fim de partida.
}

O tema da companhia perpassa toda a obra de Samuel Beckett. Os pares formados nas peças principais do autor - Vladimir e Estragon, Hamm e Clov, Winnie e Willie - já colocam em cena um dos motivos recorrentes em sua obra. Do conforto à dependência cruel, entretanto, são muitas as faces que a companhia adquire. Se nas peças citadas a existência de um personagem depende do ouvido ou da presença do outro como um contraponto fundamental, na prosa do autor, o próprio ato de narrar fornece a companhia buscada, ainda que sob intensos questionamentos.

O tema ganha mais força quando a obra Company é publicada. Escrita em 1979, o autor a teria definido como um romance para diferenciá-la de seus textos curtos escritos no período imediatamente anterior a ela ${ }^{169}$. No entanto, fica difícil enquadrá-la como tal. Além da particularidade de sua dicção e da própria estruturação do texto, a

169 Apud Souza, Ana Helena. A tradução como um outro original. Como é de Samuel Beckett. Rio de Janeiro: 7 Letras, 2006, p. 58 
obra flerta com o drama e com a lírica e está muito além da própria crise do gênero romanesco.

Diferentemente da trilogia do pós-guerra, na qual podemos ver um questionamento mais explícito sobre a forma do romance, especialmente em Molloy, os textos da fase final de Beckett adotam uma configuração muito particular, o que torna complicada a definição de acordo com um gênero específico. Um ponto comum entre os três textos da segunda trilogia, pensando em sua estrutura, é a opção do autor por narrativas mais breves. No caso de Company, também podemos apontar uma aproximação maior com o drama final do autor por conta da utilização semelhante da voz, das referências à luz e da presença do homem no escuro que ouve histórias.

A companhia, aqui, poderia ser vista como a própria obra companhia para o escritor que a escreve e para o leitor que a lê, assim como a voz é companhia para o sujeito deitado no escuro. Há um jogo de espelhos presente no texto no qual a situação do ouvinte reflete a do escritor e a do próprio leitor em uma espécie de "cadeia" em torno de uma narração que tenta se construir e na qual "o imaginador, imaginado, imagina". Voltaremos a essa questão quando comentarmos o penúltimo parágrafo da obra.

Dissemos que os textos da prosa final fazem constantes referências ao trabalho no interior da mente, mais especificamente ao momento da criação literária ou, no caso de Beckett, à tentativa de uma criação literária. Em sua análise de Worstward Ho, Pascale Casanova associa a imagem da cabeça e das mãos que aparecem mais de uma vez nesta obra a um autorretrato de Beckett, comparável ao autorretrato de Velázquez ao fundo de seu quadro As meninas ${ }^{170}$. A mesma imagem - cabeça e mãos - também dão início a Stirrings Still (1988), último texto em prosa escrito por Beckett, um

${ }^{170}$ Casanova, Pascale, op. cit., p. 25. 
ano antes de sua morte - "One night as he sat at his table head on hands he saw himself rise and go"171.

Stirrings Still apresenta muitas semelhanças com o universo da segunda trilogia beckettiana. Poderia até mesmo ser associado a esses três textos formando uma tetralogia. Há referências à passagem do tempo através das badaladas de um relógio que o narrador ouve, lembranças das caminhadas que ele costumava fazer por uma estrada erma, tentativas de piorar o texto e até mesmo uma menção à visão de Vênus, ou seja, há retomadas de situações das três obras anteriores. Em relação à IIl Seen IIl Said, este não seria o único ponto de contato. O narrador refere-se, por mais de uma vez, à sua própria figura sentada à mesa, que aparece e desaparece, algo que frequentemente ocorre com as imagens em IIl Seen IIl Said:

One night or day then as he sat at his table head on hands he saw himself rise and go [...] So slow that only change of place to show he went. As when he disappeared only to reappear later at another place. Then disappeared again only to reappear again later at another place again. So again and again disappeared again only to reappear again later at another place again. Another place in the place where he sat at his table head on hands ${ }^{172}$.

Nesse último texto, talvez até mais fortemente do que nos outros três, por conta da própria cena do homem sentado à mesa e da evocação de situações já presentes em textos anteriores, teríamos uma aproximação mais explícita com o ofício do escritor. O que une

\footnotetext{
${ }^{171}$ Beckett, S. Stirrings Still. In: Samuel Beckett. The Grove Centenary Edition. Vol. IV. Poems, Short Fiction, Criticism. New York: Grove Press, 2006., p. 487. " Uma noite enquanto estava sentado à sua mesa cabeça nas mãos viu-se levantar e partir". (Beckett, S. Sobressaltos. In: Companhia e outros textos. Trad. Ana Helena Souza. São Paulo: Globo, 2012, p. 89)

172 Idem, p. 487-8. "Uma noite ou dia então enquanto estava sentado à sua mesa cabeça nas mãos viu-se levantar e partir [...] Tão devagar que só a mudança de lugar para mostrar que ia. Como quando desaparecia só para reaparecer depois em outro lugar. Então desaparecia de novo só para reaparecer de novo depois em outro lugar de novo. Assim de novo e de novo desaparecia de novo só para reaparecer de novo depois em outro lugar de novo. Outro lugar no lugar onde se sentava à sua mesa cabeça nas mãos". (Beckett, S. Sobressaltos, op. cit., p. 90)
} 
essas quatro obras da fase final é justamente o processo da criação literária.

Voltando à Company, o sujeito deitado no escuro também pode ser associado à figura do escritor em uma postura reflexiva, imaginando, criando. Também já salientamos que a presença da reflexão sobre a obra dentro da própria obra é uma marca desses textos. Quais seriam, então, as especificidades de Company dentro desse universo final beckettiano? Em que medida ela se destaca?

O objetivo da terceira parte deste trabalho é buscar essa resposta, pensando sobre os significados do tema da companhia dentro da obra do autor e estudando alguns elementos constitutivos deste texto.

Em uma fase marcada pela fragmentação, Company ainda conjuga dois "estilos narrativos". De acordo com Gregory Johns: "What's clear about Company is that it veers between a traditional text, with its evocations of images and memories, and a postmodern revision of fiction, where every step in the naturalistic evocation process is questioned"173. De fato, o que primeiramente nos chama a atenção na obra é essa duplicidade da narração. Há as passagens atribuídas ao narrador propriamente e aquelas atribuídas à voz que, em Company, ocupa uma posição especial. Começaremos por ela.

173 Johns, Gregory. In the dim void. Samuel Beckett's late trilogy. Company, III Seen III Said and Worstward Ho. England: Crescent Moon Publishing, 1993, p. 23. "O que é claro sobre Company é que a obra se move entre um texto tradicional, com suas evocações de imagens e memórias, e uma revisão pós-moderna da ficção, na qual cada passo no processo de evocação naturalista é questionado". 


\subsection{O narrador-voz}

Mencionamos a presença da voz como uma característica marcante da ficção de Beckett principalmente a partir de L'innommable, mas é em Company que ela se sobressai.

A origem e o significado desta voz sempre foram alvos de investigação dos pesquisadores beckettianos. Gontarski a considera a "criação literária mais profunda" de Beckett, sendo o romance L'innommable o auge de sua exploração na prosa do autor. O crítico vê seu surgimento como uma derivação do conceito de "monólogo interior" reconfigurado pelo autor:

Beckett's exploration of these questions admittedly took a variety of forms: an early fascination first with echo, then with the schizophrenic voice; his need, expressed in the "German Letter of 1937 " to find some kind of Nominalist irony en route to the unword; his attempt in the fiction from Three Novels to Company to determine the nature and location of that impossible imperative, the need to express; and finally his representations in the theater of a dramatic voice beyond the constrictions and conventions of the interior monologue, beyond the coherence of ego and character, difficulties that dominated the so-called mature fiction as well ${ }^{174}$.

Na obra Transparent Minds. Narrative Modes for Presenting Consciousness in Fiction (1978), Dorrit Cohn cria uma tipologia para a narração da consciência em terceira e em primeira-pessoa. No capítulo intitulado "Autonomous Monologue", que teria o monólogo de Penélope em Ulisses como paradigma, Cohn comenta as possíveis

174 Gontarski, S.E. Beckett and the Unnamable Voice of (European) Modernism. In : Journal of Beckett Studies, vol. 13, number 2, Spring 2004, p.177. "A exploração de Beckett em torno dessas questões reconhecidamente tomou diversas formas: um fascínio inicial primeiramente com o eco, depois com a voz esquizofrênica; sua necessidade, expressa na "Carta Alemã de 1937", de encontrar algum tipo de ironia Nominalista em direção à despalavra; sua tentativa na ficção da Trilogia até Companhia em determinar a natureza e a localidade desse imperativo impossível, a necessidade de expressar; e finalmente suas representações no teatro de uma voz dramática para além das constrições e convenções do monólogo interior, para além da coerência do ego e personagem, dificuldades que também dominaram a chamada ficção madura". 
variações desse tipo de narração. Ela chama a atenção para o fato de que, em vários monólogos interiores, o falante se desdobra em ouvinte e refere-se a si mesmo como tal através do uso da segundapessoa narrativa. Um dos exemplos usados por Cohn é de Senhorita Else (1924), de Arthur Schnitzler:

Am I really as beautiful as I look in the mirror? Oh, won't you come closer, beautiful lady. I want to kiss your blood-red lips. I want to press your breasts to my breasts. What a pity that there is this glass between us, this cold glass. How well we would get on together. Don't you agree? We would need no one else ${ }^{175}$.

A ideia do personagem que se duplica e conversa consigo mesmo também apareceria em Company, se considerarmos a voz como uma manifestação da consciência do próprio ouvinte, algo que o final da obra parece comprovar. Nesse caso, o autor estaria, como reflete Gontarski, explorando os limites do monólogo interior. Entretanto, a insistência por definir as características físicas da voz altura do som, distância do ouvinte, tom monótono - parecem distanciá-la de algo inerente ao sujeito, dramatizando-a. Parece haver uma tentativa de torná-la visível e exterior. Sua manifestação assemelha-se àquela que ocorre em algumas peças do autor, como That Time e A piece of monologue.

Neste mesmo capítulo, Cohn comenta que uma das características do "monólogo autônomo" é a aproximação com outros gêneros - lírica e drama - justamente por essa modalidade conter menos elementos tipicamente narrativos. É a forma que mais se aproximaria da expressão pura de uma consciência. Ela aponta a

175 Schnitzler, Arthur. Fraülein Else apud Cohn, Dorrit. Transparent Minds. Narrative Modes for Presenting Consciousness in Fiction. Princeton, New Jersey: Princeton University Press, 1978 , p. 246. "Sou realmente tão bonita quanto pareço no espelho? Oh, venha mais perto moça bonita. Eu quero beijar seus lábios vermelhos como sangue. Quero apertar seus seios contra os meus seios. Que pena existir esse vidro entre nós, esse vidro frio. Como nos daríamos bem juntas. Você não concorda? Não precisaríamos de mais ninguém". 
qualidade dramática dos monólogos de Penélope e Senhorita Else, inclusive já levados ao palco. Sobre Not I e Krapp's Last Tape, Cohn diz: "Beckett is probably the playwright who comes closest to realizing monodrama in the theater, but even the single open mouth in Not I addresses a silent listener on stage, and Krapp carries on something of a dialogue with his last tape"176.

O foco de Cohn no trecho citado é refletir sobre que forma seria análoga ao monólogo autônomo no drama. No entanto, ela acaba chamando a atenção para uma característica do drama final de Beckett. Mesmo quando os personagens estão sozinhos em cena, a solidão não é completa. Há sempre um contraponto fornecendo companhia, conforme dissemos no início. Krapp conversa com suas fitas e a Boca conta com a presença do ouvinte em cena. Em A piece of monologue, cujo próprio título indica um monólogo, não é o ator em cena quem fala. Ele ouve uma voz assim como em Company.

Chris Ackerley vê a aparição do tema da voz como uma reflexão de Beckett a partir da famosa palestra de Jung que o autor assistiu em 1935, assunto que Gontarski também desenvolve em seu artigo. Na referida palestra, Jung fala sobre a origem das vozes ouvidas por pacientes esquizofrênicos. Ackerley ainda diz que o desenho da mente de Murphy, presente neste romance, é baseado em um desenho de Jung apresentado na mesma ocasião - esferas concêntricas representando gradações da mente, da luz da consciência rumo à escuridão do inconsciente coletivo ${ }^{177}$.

Em seu estudo sobre a voz performativa na obra de Beckett, Sarah West também persegue o tema, mostrando que a preocupação

\footnotetext{
176 Cohn, D., op. cit., p. 257. "Beckett é provavelmente o dramaturgo que chega mais perto de concretizar o monodrama no teatro, mas mesmo a boca solitária em Not I dirige-se a um ouvinte silencioso no palco, e Krapp mantém algo semelhante a um diálogo com sua última fita".

177 Ackerley, Chris. The Uncertainty of Self: Samuel Beckett and the Location of Voice. In: Uhlmann, Anthony, Houppermans, Sjef \& Clément, Bruno (Ed.) .Samuel Beckett Today/Aujourd' hui. After Beckett. D'après Beckett. Amsterdam/New York: Rodopi, 2004.
} 
com a voz estava presente desde "Assumption", primeiro conto publicado do autor. West chama a atenção para o fato de que, neste conto, há muitos detalhes referentes às descrições das vozes dos personagens, o que apontaria para um esforço de Beckett no sentido de descrever o que o leitor não poderia ouvir ${ }^{178}$.

Podemos citar ainda um depoimento de Pierre Chabert, ator e diretor de diversas peças do autor, para quem Beckett teria dito, antes de morrer: "A voz à qual me refiro tão obstinadamente em minha obra é realmente uma voz externa. Aquela voz está fora de mim". Beckett estaria, com esta declaração, criticando a decisão de Chabert de usar a própria voz do ator em cena para os parágrafos referentes à voz em sua adaptação de Company, em 1986. Beckett queria que Chabert usasse uma voz gravada na montagem ${ }^{179}$.

Especulações à parte, o que podemos afirmar é que, da mesma forma com a qual o narrador assume configurações distintas ao longo da trajetória em prosa beckettiana, também a voz sofre mutações até chegar ao ponto em que, ela mesma, se configura em narrador. É o que acontece em Company.

Vejamos o terceiro parágrafo da obra: "Use of the second person marks the voice. That of the third that cankerous other. Could he speak to and of whom the voice speaks there would be a first. But he cannot. He shall not. You cannot. You shall not"180. Aqui há uma explicação sobre a escolha da segunda-pessoa narrativa para definir esta voz. Não há mais espaço para a primeira-pessoa, uma vez que não existe aderência entre o sujeito e as memórias narradas pela voz; tampouco para a terceira, descrita como a voz do outro narrador

\footnotetext{
${ }^{178}$ Ver West, Sarah. Say it. The performative voice in the dramatic works of Samuel Beckett. Amsterdam/New York: Rodopi, 2010, p.37-9.

${ }^{179}$ Ver Oppenhein, Lois (Ed). Interviews. Pierre Chabert. In : Directing Beckett. Michigan: The University of Michigan Press, 1997, p. 71

${ }^{180}$ Company, p. 427. "O uso da segunda-pessoa marca a voz. O da terceira aquele outro pustulento. Se ele pudesse falar para e de quem a voz fala haveria uma primeira. Mas ele não pode. Ele não vai. Você não pode. Você não vai". (Companhia, op. cit., p. 28)
} 
- "that cankerous other". Podemos ler aqui tanto uma crítica à narração tradicional, ao típico narrador onisciente, estilo que Beckett veio combatendo desde cedo, como também ao uso da primeirapessoa tão explorada por ele nas obras de sua segunda fase. A voz caracteriza um novo tipo de narrador beckettiano. Mais uma vez, busca-se um caminho para continuar.

Os trechos finais do parágrafo chamam a atenção pela dubiedade - "But he cannot. He shall not. You cannot. You shall not". O narrador refere-se ao criador da obra (he), mas quando fala na segunda -pessoa (you) alcança tanto esse criador como também parece se dirigir ao leitor. O leitor também não pode e também não vai saber ao certo "de quem ou para quem a voz fala", uma vez que o texto salienta justamente esta incerteza.

Esse jogo narrativo é uma particularidade importante da narração de Company. O narrador central se manifesta na própria obra através da figura denominada "criador", mas comenta o que esse criador faz e imagina o que se passa como se estivesse de fora, mantendo um distanciamento. A proposta da obra condensa-se na abertura do quadragésimo-quarto parágrafo: "Devised deviser devising it all for company". A frase-chave de Company gira na cabeça do leitor. Há um inventor (escritor/narrador), inventado (o criador), inventando tudo para ter companhia.

A voz está fora desse esquema. Suas manifestações tem uma autonomia, apesar dela também ter sido imaginada pelo narrador central. Vamos, portanto, considerar que temos duas instâncias narrativas em Company, uma vez que as incursões da voz são realmente bastante típicas e diferentes dos comentários do narrador central. Em uma gravação radiofônica de Compagnie realizada por Roger Blin, a solução encontrada para marcar a independência da voz 
foi a inclusão de uma música com uma espécie de eco para caracterizar suas manifestações ${ }^{181}$.

A investigação sobre os recursos da voz também nos leva a refletir sobre as peças radiofônicas do autor. Everett Frost comenta que, com seu trabalho no rádio, Beckett explorou as possibilidades da verbalização sonora na ausência de elementos visuais. O meio radiofônico seria, dessa forma, ideal para representar as "vozes desencarnadas" e também explorar o monólogo interior. Seria uma alternativa ao impasse atingido com a escrita de L'innommable ${ }^{182}$.

As experiências realizadas no rádio devem ter influenciado a opção pelo ouvinte no escuro a quem as histórias chegam em Company. Se estar sozinho no escuro é a condição do espectador no teatro, a condição de quem ouve uma peça no rádio também sugere uma concentração solitária. Beckett migrava para outros meios em busca de alternativas para as mesmas questões, novos tratamentos para os mesmos temas. No entanto, vale salientar que ele explorava ao máximo os recursos de cada meio artístico em si. No caso do rádio e da parceria com a BBC, há diversos relatos mostrando a preocupação do autor com a caracterização do som, das vozes, da música, dos ruídos ${ }^{183}$. Ele criava levando em conta um meio específico. Daí decorrem as dificuldades de adaptação para os meios nos quais os trabalhos não foram originalmente pensados.

181 Ver Compagnie. In: Dimanche, Andre (Ed.) Samuel Beckett. Documents Sonores. Bry sur Marne, France: Institut National de I' Audiovisuel, 2007.

${ }^{182}$ Frost, Everett C. 'The sound is enough'. Beckett's Radio Plays. In: Gontarski, S. E. (Ed). The Edinburgh Companion to Samuel Beckett and the Arts. Edinburgh: Edinburgh University Press, 2014.

${ }^{183}$ Além dos artigos já citados de Everett Frost e Jonathan Kalb sobre o assunto "The sound is enough. Beckett's Radio Plays" e "The mediated Quixote: the radio and television plays, and Film" - podemos citar um artigo de Martin Esslin sobre as produções radiofônicas de Beckett (Ver Esslin, Martin. Samuel Beckett and the Art of radio. In: Gontarski, S.E. (Ed). On Beckett. Essays and Criticism. London: Anthem Press, 2014). O livro de Clas Zilliacus Beckett and broadcasting: a study of the works of Samuel Beckett for and in radio and television também é uma referência para os estudos das peças radiofônicas beckettianas. (Abo: Abo Akademi, 1976) 
$\mathrm{Na}$ própria trajetória das peças radiofônicas de Beckett, podemos observar esse caminho para o interior da mente que viemos descrevendo na prosa. Em All That Fall (1957), a primeira incursão de Beckett pelo rádio, acompanhamos o percurso da protagonista Maddy Rooney rumo a uma estação de trem, para a qual ela se dirige com o objetivo de buscar seu marido, Dan. Diversos personagens e vozes cruzam com Maddy pelo caminho, entretanto, é a partir de sua visão e de sua voz que nós, transformados em ouvintes, seguimos a peça. $\mathrm{Na}$ gravação realizada e veiculada pela BBC, a atriz Mary O'Farrel aproxima-se mais do microfone do que os outros atores, justamente para reforçar a impressão de que acompanhamos a história através de sua consciência ${ }^{184}$.

All That Fall apresenta uma caracterização palpável dos personagens e uma situação narrativa definida. Toda a ação transcorre no período em que Maddy vai até a estação de trem e retorna com seu marido. Há um mistério envolvendo o atraso do trem em que Dan viaja, o clímax da história, e a revelação do ocorrido no final. Essa estrutura mais tradicional já não aparece em Embers (1959), peça radiofônica escrita na sequência, totalmente centrada nas divagações da mente de Henry. A linguagem do protagonista de Embers é bem mais confusa que a de Maddy e os personagens que surgem não chegam a se configurar concretamente, são apenas lembranças do protagonista. As rubricas para as falas de Ada, esposa de Henry, marcam essa condição espectral. Sua voz deve ser baixa e remota. A indicação sugere uma presença distante, não física. Billie Whitelaw teria questionado Beckett sobre o papel, quando preparavase para interpretá-lo em uma produção dirigida pelo próprio Frost. $\mathrm{O}$ escritor insistiu na ambiguidade relativa à fisicalidade de Ada dizendo: "Digamos que você não está completamente lá", instrução que ele também teria dado a Whitelaw na ocasião em que a atriz

\footnotetext{
184 Tais detalhes da gravação são mencionados no texto já citado de Jonathan Kalb.
} (Ver Kalb, J. The Cambridge Companion to Beckett, p. 127) 
representou May, em Footfalls ${ }^{185}$. Dois anos após a escrita de All That Fall, sua próxima experiência radiofônica já se encaminha para uma interiorização maior no "manicômio do crânio", aproximando-se dos textos em prosa de sua fase final.

Saindo das explorações da voz no rádio e voltando para a prosa, podemos dizer que em obras como L'innommable e Textes pour rien, a voz funcionava com um caráter negativo e tirânico - era ela que não permitia que o narrador alcançasse o silêncio. Em Company, ela desempenha uma função distinta. Essa distinção talvez tenha levado Beckett a mudar a forma com a qual ela se manifesta, retirando-a da possível associação com uma voz interna do narrador através de sua externalização na própria estrutura do texto. Company é a única obra em prosa em que isso acontece. Outro traço de diferenciação da voz nesta obra é sua musicalidade monótona e repetitiva. Tais características não são apontadas em outros textos. Poderíamos, ainda assim, encontrar um caráter tirânico dissimulado em sua musicalidade monótona. A insistência em fazer com que o sujeito se recorde do que é dito e o uso do pronome você para se referir a ele trazem um tom autoritário ao seu discurso. A voz se impõe sobre o sujeito e se destaca como narrador.

Ana Helena Souza comenta as ocorrências da voz na obra beckettiana chamando a atenção para a disputa que gradativamente se constroi entre ela e o narrador das histórias:

É notável a diferença em relação à presença de vozes em Watt, por exemplo. Neste romance, elas surgiam e desapareciam de maneira esparsa, como um sintoma da loucura do protagonista, sem nem de longe se desenvolverem em um elemento a partir do qual a própria narrativa se formava. Em $O$ Inominável, referências a vozes indeterminadas tornam-se não apenas constantes, mas integram o próprio texto, como um dos elementos de elaboração da enunciação. Ou seja, essas vozes indeterminadas irão cada vez mais disputar o

${ }^{185}$ Ver Frost, op cit., p. 257-8. 
lugar do narrador até passarem a problematizar a sua autoridade enquanto narrador único, tanto em Como é, quanto em Companhia $(1980)^{186}$.

A voz qua qua presente em Como é, na análise de Ana Helena Souza, cumpre a função de fornecer ao texto uma espécie de onisciência, uma "ampliação de visão" que o narrador-personagem da obra não poderia ter ${ }^{187}$. Já em Como é, haveria, portanto, uma tentativa de externalizar essa voz e atribuir a ela uma função própria, expediente mais difícil de se apontar em obras anteriores do autor que também fazem uso deste recurso.

Além de problematizar a autoridade da narração, o que parece ocorrer é uma escolha do autor pela cisão narrativa, fragmentando as origens do discurso. No caso de Company ela é ainda mais radical, a voz está separada do resto do texto, tem não apenas autonomia, como um objetivo próprio - evocar as supostas memórias do sujeito e fazer com que ele se lembre delas. Sob este aspecto é interessante pensar na opção do autor pela exteriorização da voz na obra. Fica sob a responsabilidade dela o que para o típico narrador beckettiano seria impossível - narrar linearmente e claramente, sem nenhuma angústia narrativa. Os parágrafos referentes à voz trazem essa marca. Temos, portanto, dentro da complexa estrutura da obra, um retorno de elementos narrativos mais tradicionais na tentativa de composição de uma história de vida, sempre negada pela ausência de lembrança do sujeito no escuro.

Vale, contudo, reparar que a angústia não aparente na narração desses trechos acaba surgindo no conteúdo das supostas memórias. As histórias que a voz traz são, em sua quase totalidade, marcadas por momentos desconfortáveis, indo da infância à velhice do sujeito. A resposta áspera da mãe (parágrafo 7 ) deixa o menino sozinho em

\footnotetext{
${ }^{186}$ Souza, Ana Helena. A tradução como um outro original. Como é de Samuel Beckett. Rio de Janeiro: 7letras, 2006, p. 43.

${ }^{187}$ Idem, p. 91-2.
} 
sua confusão, sem entender o que a irritou. A descrição do dia de seu nascimento (parágrafo 9) ressalta o incômodo de seu pai no momento do parto. O medo do menino quando o pai pede para que ele mergulhe do trampolim marca o parágrafo 16 . Suas brincadeiras solitárias - os saltos da árvore e as tentativas de enxergar ao longe aparecem nos parágrafos 24 e 29. Duas das lembranças associadas à infância ressaltam o desejo da criança em ser útil e fazer uma boa ação - a cena em que ele abre o portão para uma velha mendiga (parágrafo 13) e o momento no qual ele decide proteger o ouriço (parágrafo 33). Especificamente no trecho referente ao ouriço temos um efeito inverso à boa intenção do menino. Após resgatá-lo do frio e arranjar-Ihe um lar confortável, ele acaba sentindo-se responsável pela morte do animal:

You take pity on a hedgehog out in the cold and put it in an old hatbox with some worms. This box with the hog inside you then place in a disused hutch wedging the door open for the poor creature to come and go at will. To go in search of food and having eaten to regain the warmth and security of its box in the hutch. There then is the hedgehog in its box in the hutch with enough worms to tide it over. A last look to make sure all is as it should be before taking yourself off to look for something else to pass the time heavy already on your hands at that tender age. The glow at your good deed is slower than usual to cool and fade [...] Now the next morning not only was the glow spent but a great uneasiness had taken its place. A suspicion that all was perhaps not as it should be. That rather than do as you did you had perhaps better let good alone and the hedgehog pursue its way. Days if not weeks passed before you could bring yourself to return to the hutch. You have never forgotten what you found then. You are on your back in the dark and have never forgotten what you found then. The mush. The stench ${ }^{188}$.

${ }^{188}$ Company, p. 436-7. "Você tem pena de um ouriço- cacheiro no frio lá fora e o coloca numa velha caixa de chapéu com algumas minhocas. Essa caixa com o ouriço dentro você põe então num viveiro de coelhos abandonado calçando a porta para que a pobre criatura vá e venha à vontade. Para ir em busca de alimento e tendo comido recobrar o calor e a segurança de sua caixa no viveiro. Então lá está o ouriço em sua caixa no viveiro com minhocas bastantes para provê-lo. Uma última olhada para se certificar de que tudo está como deveria antes de se mandar à procura de outra coisa com que passar o tempo já pesando em suas mãos naquela tenra idade. O entusiasmo com o seu belo feito demora mais que de costume para esfriar e perder o brilho. [...] Agora na manhã seguinte não só o entusiasmo se extinguira mas uma grande inquietação tinha tomado o seu lugar. Uma suspeita de que tudo não fora como deveria ter sido. Que em vez de ter feito 
O trecho é significativo pois é a última passagem referente à infância do sujeito e traz uma recordação ruim, que ele jamais teria esquecido. O propósito da boa ação se esvai, o tom é de desencanto e a voz ressalta que o tempo já pesava a ele "naquela tenra idade", motivo que o levava a procurar por passatempos. O último deles, a "adoção" do ouriço, termina com o enfrentamento da morte e a consequente reflexão do menino sobre seu papel nesse desenlace.

As manifestações da voz referentes à infância aparecem em maior número na obra, mas há ainda os parágrafos referentes à juventude (40 e 48) e aqueles que mostram o sujeito em idade avançada (10, 27, 39 e 53). Em relação à velhice, os três primeiros trechos referem-se às caminhadas que o sujeito costumava fazer e à lembrança do pai, além de também tratarem de sua necessidade de calcular a distância do caminho, contar seus passos, mais um passatempo e obsessão beckettiana já apontados.

Dentre os trechos associados à velhice, gostaria de chamar a atenção para o parágrafo 53. Ele traz a imagem do sujeito na praia, apoiado em seu cajado, enquanto ouve o barulho do mar. Neste trecho, encontramos uma consonância entre o som do marulho (cena do suposto passado) e o som da voz (cena do presente da narração) como se os dois tipos de narração se fundissem. Vejamos:

A strand. Evening. Light dying. Soon none left to die. No. No such
thing then as no light. Died on to dawn and never died. You stand
with your back to the wash. No sound but its. Ever fainter as it slowly
ebbs. Till it slowly flows again. You lean on a long staff. Your hands
rest on the knob and on them your head. Were your eyes to open
they would first see far below in the last rays the skirt of your
greatcoat and the uppers of your boots emerging from the sand.
Then and it alone till it vanishes the shadow of the staff on the sand.

o que fez teria sido melhor deixar o bem em paz e o ouriço-cacheiro seguir seu caminho. Dias se não semanas se passaram antes que você conseguisse se convencer a voltar ao viveiro. Você nunca esqueceu o que encontrou então. Você está deitado de costas no escuro e nunca esqueceu o que encontrou então. A papa. O fedor". (Companhia, p. 41-2) 
Vanishes from your sight. Moonless starless night. Were your eyes to open dark would lighten ${ }^{189}$.

Temos aqui, logo no início, uma descrição da luz do entardecer e do som do marulho. O trecho evoca as descrições da manifestação da voz mencionadas nos parágrafos 14 e 18 e as respectivas mudanças de luz que a acompanham. Além disso, o parágrafo 18 também menciona a diferença no tom da escuridão quando os olhos do sujeito deitado no escuro se abrem:

A faint voice at loudest. It slowly ebbs till almost out of hearing. Then slowly back to faint full. At each slow ebb hope slowly dawns that it is dying. He must know it will flow again. And yet at each slow ebb hope slowly dawns that it is dying ${ }^{190}$.

By the voice a faint light is shed. Dark lightens while it sounds. Deepens when it ebbs. Lightens with flow back to faint full. Is whole again when it ceases. You are on your back in the dark. Had the eyes been open then they would have marked a change ${ }^{191}$.

No parágrafo 53 , portanto, na própria descrição da cena na praia, percebemos uma fusão entre as duas instâncias narrativas, como se $o$ narrador central se inserisse sorrateiramente na

189 Company, p. 446. "Uma praia. Entardecer. Luz morrendo. Logo nenhuma de sobra para morrer. Não. Nada assim então como nenhuma luz. Ia morrendo até a madrugada e nunca morria. Você está em pé de costas para o marulho. Nenhum som só o dele. Cada vez mais fraco à medida que reflui. Até lentamente fluir de novo. Você se apoia num cajado comprido. Suas mãos descansam no cabo e nelas sua cabeça. Se os seus olhos se abrissem veriam primeiro lá embaixo nos últimos raios a aba de seu casaco e as gáspeas de suas botinas emergindo da areia. Então e somente ela até ela desaparecer a sombra do cajado na areia. Desaparecer da sua vista. Noite sem lua nem estrelas. Se os seus olhos se abrissem o escuro clarearia". (Companhia, p. 57)

${ }^{190}$ Company, p. 431. "Uma voz fraca na altura máxima. Ela reflui devagar até ficar quase inaudível. Então volta devagar para o seu máximo fraco. A cada refluxo lento a esperança desponta lentamente de que ela esteja morrendo. Ele deve saber que ela fluirá outra vez. E entretanto a cada refluxo lento a esperança desponta lentamente de que ela esteja morrendo" (Companhia, p. 33).

${ }^{191}$ Company, p. 432. "Pela voz uma luz fraca é emitida. A escuridão clareia enquanto soa. Aprofunda-se quando reflui. Clareia com o refluxo até o fraco total. É completa outra vez quando ela cessa. Você está deitado de costas no escuro. Estivessem os olhos abertos então teriam notado uma mudança". (Companhia, p. 34-5) 
manifestação da voz fazendo com que o leitor perceba esse eco através da repetição dos termos.

Em The ideal real. Beckett's Fiction and Imagination (1994), Paul Davies comenta essa fusão de tons em alguns trechos de Company ${ }^{192}$. Ele estende essa mescla para outros dois parágrafos da obra (25 e 47). Davies menciona que, em alguns momentos, a voz é bastante específica e inclusive nomeia lugares e objetos, algo raro na obra de Beckett. Seria o caso da menção às lojas Connolly (parágrafo 7), ao carro De Dion Bouton (parágrafo 9) e ao atlas Longman (parágrafo 29). No entanto, em outros momentos há essa fusão entre o tempo do passado e o do presente da narração, o que torna certos trechos mais evasivos e misteriosos, caso da cena na praia. Sobre este trecho, Davies diz:

\begin{abstract}
This is interpretable as one of the autobiographical scenes, but the mystery of it - its sound and its lack of specifying objects - makes it generically different from the paragraphs in which Connolly's Stores and "wafer-thin bread and butter" feature so easily, and so appropriately to autobiography. This passage is more timeless, and it was obviously important enough to Beckett for him also to include it - from "Light dying" to "never died" - in his short play A Piece of Monologue. In one sense it may be as abstract as the "narrativepresent" passages describing the crawling and devising, but it is connected in sound, reference and style with something much larger than everyday world, its objects and "the common light of day"193.
\end{abstract}

Davies está chamando a atenção para as sutilezas narrativas de alguns trechos, nos quais a separação entre os dois tipos de narração

192 Refiro-me especificamente ao capítulo 8 da obra. Ver Davies, Paul. The Imagination of Youth (Company). In: The Ideal Real. Beckett's Fiction and Imagination. London and Toronto: Associated Universities Presses, 1994.

193 Idem, p. tal. "Ela é interpretável como uma das cenas autobiográficas, mas seu mistério - sua sonoridade e a falta de objetos específicos - torna-a genericamente diferente dos parágrafos nos quais as lojas Connoly e as "fatias de pão com manteiga finas feito hóstias" caracterizam tão facilmente e apropriadamente uma autobiografia. Essa passagem é mais atemporal, e obviamente era bastante importante para Beckett para que ele também a incluísse - de "Luz morrendo" a "nunca morria" - em sua peça curta A Piece of monologue. Em um sentido pode ser tão abstrata como as passagens da "narrativa no presente" descrevendo o rastejamento e a imaginação, mas está conectada em som, referência e estilo com algo bem maior do que o mundo cotidiano, seus objetos e "a luz comum do dia". 
não é tão clara, como se um adentrasse no modo de narrar do outro. Ele também menciona o parágrafo 25 como um exemplo dessa fusão entre dois tons. Se analisarmos a passagem detidamente, podemos observar que o comentário do narrador central parece dialogar com a manifestação da voz do parágrafo imediatamente anterior. Para ficar mais claro, vejamos a sequência referente aos parágrafos 24 e 25:

\begin{abstract}
You are alone in the garden. Your mother is in the kitchen making ready for afternoon tea with Mrs. Coote. Making the wafer-thin bread and butter. From behind a bush you watch Mrs. Coote arrive. A small thin sour woman. Your mother answers her saying, $\mathrm{He}$ is playing in the garden. You climb to near the top of a great fir. You sit a little listening to all the sounds. Then throw yourself off. The great boughs break your fall. The needles. You lie a little with your face to the ground. Then climb the tree again. Your mother answers Mrs. Coote saying, He has been a very naughty boy.

What with what feeling remains does he feel about now as compared to then? When with what judgement remained he judged his condition final. As well enquire what he felt then about then as compared to before. When he still moved or tarried in remains of light. As then there was no then so there is none now ${ }^{194}$.
\end{abstract}

A diferença entre os dois trechos é notável. Se no primeiro parágrafo citado, uma nítida manifestação da voz, lemos essa narração do dia a dia, vemos ou imaginamos o menino brincando e subindo na árvore enquanto a mãe toma chá com a amiga, o segundo parágrafo nos transporta para uma reflexão do narrador sobre os sentimentos do ouvinte em uma linguagem totalmente distinta da do

${ }^{194}$ Company, p. 433. "Você está sozinho no jardim. A sua mãe está na cozinha se preparando para o chá da tarde com Mrs. Coote. Preparando as fatias de pão com manteiga finas feito hóstias. Detrás de um arbusto você vê Mrs. Coote chegar. Uma mulher pequena magra amarga. Sua mãe responde a ela dizendo, Ele está brincando no jardim. Você sobe quase até o topo de um grande abeto. Você se senta um pouco ouvindo todos os sons. Então se joga. Os grandes galhos interrompem a sua queda. As agulhas. Você fica deitado um pouco com o rosto no chão. Então sobe na árvore outra vez. Sua mãe responde a Mrs Coote outra vez dizendo, Ele tem sido um menino muito levado.

O que com o tanto de sentimento que resta ele sente sobre o agora comparado ao então? Quando com o tanto de juízo que restava ele julgava a sua condição final. Assim como inquirir o que ele sentia então sobre o então comparado ao antes. Quando ainda se movia ou se detinha em restos de luz. Como então não havia então também não há nenhum agora". (Companhia, p. 36) 
parágrafo anterior. Enquanto que no primeiro trecho, o discurso é mais corriqueiro e segue uma linearidade mais próxima da prosa, no segundo, encontramos as características que viemos definindo como próximas da linguagem lírica, inversões gramaticais, elipses e forte musicalidade. No entanto, diferentemente dos parágrafos nos quais o narrador discute a própria feitura de seu texto, marca deste narrador central, aqui ele se refere ao sentimento do ouvinte associado à memória trazida pelo trecho anterior - "O que com o tanto de sentimento que resta ele sente sobre o agora comparado ao então?" - associando os dois trechos de uma forma que não ocorre no restante da obra. Essa característica traria uma peculiaridade para o parágrafo 25 pois, apesar de ser um comentário do narrador, ele surge diretamente ligado à manifestação da voz, causando essa espécie de fusão que Davies menciona.

No caso do parágrafo 47, o último mencionado por Davies, o narrador central reflete sobre qual seria a melhor posição para o repouso da voz. Vejamos: "Arm's lenght. Force? Low. A mother stooping over cradle from behind. She moves aside to let the father look. In his turn he murmurs to the newborn. Flat tone unchanged. No trace of love"195. O que temos aqui é mais uma mescla entre passado e presente em um mesmo trecho. O narrador associa o tom da voz que narra ao tom da voz do pai debruçado sobre o berço do recém-nascido - "Tom monocórdio inalterado. Nenhum traço de amor". Teríamos, dessa forma, além das manifestações clássicas do narrador-voz, nas quais claramente percebemos as passagens da vida do sujeito, trechos híbridos, nos quais os dois tipos de narração parecem se fundir e dialogar.

195 Company, p. 444. "Ao alcance do braço. Força? Fraca. Uma mãe curvando-se sobre o berço por trás. Ela se afasta para que o pai possa olhar. Por sua vez ele murmura para o recém-nascido. Tom monocórdio inalterado. Nenhum traço de amor." (Companhia, p. 53) 
A voz se manifesta através de um discurso mais acessível e próximo de uma narração tradicional. Esses trechos proporcionam um respiro em meio às elucubrações e investigações do narrador, trazendo o leitor para o centro de uma história de vida, ou partes dela. Ela tenta atingir seu objetivo através dessa contação de histórias - "Para melhor erodir o pingo deve bater sem se desviar. No que está embaixo"196. Curiosamente, esses trechos mais próximos de uma narração tradicional não convencem o ouvinte, não são entendidos por ele.

A voz que chega a alguém deitado no escuro também coloca em discussão a percepção de mundo do sujeito através de sua audição e também de seu tato, uma vez que a consciência de sua situação se dá pela sensação da parte posterior de seu corpo no chão: "To one on his back in the dark. This he can tell by the pressure on his hinds parts and by how the dark changes when he shuts his eyes and again when he opens them again" ${ }^{197}$. Entretanto, o sentido que se destaca aqui é o da audição.

A importância do papel da audição em Company também se compara à da peça Ohio Improptu (1982). Escritas no mesmo período, ambas trazem o tema da narrativa como companhia indispensável.

\footnotetext{
196 Companhia, p. 44.

197 Company, p. 427. "A alguém deitado de costas no escuro. Isso ele pode dizer pela pressão nas partes traseiras e pela mudança do escuro quando ele fecha os olhos e de novo quando os abre de novo". (Companhia, op. cit., p. 27)
} 


\title{
3.2. "Alone together" - ficção como companhia
}

O papel da ficção como companhia sempre esteve presente na prosa de Beckett. Se voltarmos às novelas escritas em francês, podemos citar um exemplo de Le calmant (1955), na qual o narrador-protagonista menciona a história de Joe Breen, narrativa que gostava de ouvir seu pai contar e sem a qual não conseguia dormir:

\begin{abstract}
Oui, il faut ce soir que ce soit comme dans le conte que mon père me lisait, soir après soir, quand j'étais petit, et lui en bonne santé, pour me calmer, soir après soir, pendant des années il me semble ce soir, et dont je n'ai pas retenu grand'chose, sauf qu'il s'agissait des aventures d'un nommé Joe Breem, ou Breen, fils d'un gardien de phare, jeune gaillard de quinze ans fort et musclé, c'est la phrase exacte, qui nagea pendant des milles, la nuit, un couteau entre les dents, à la poursuite d'un requin, je ne sais plus pourquoi, par simple héroïsme. Ce conte, il aurait pu simplement me le conter, il le savait par coeur, moi aussi, mais cela ne m'aurait pas calmé, il devait me le lire, soir après soir, ou faire semblant de me le lire, en tournant les pages et en m'expliquant les images, qui étaient moi déjà, soir après soir les mêmes images, jusqu'a à ce que je m'assoupisse contre son épaule ${ }^{198}$.
\end{abstract}

Em Malone Meurt (1951), também o narrador decide se contar histórias enquanto aguarda pela sua morte, mais uma forma de ter alguma companhia: "D'ici là je vais me raconter des histoires, si je peux. Ce ne sera pas les même genre d'histoires qu'autrefois, c'est

198 Beckett, S. Le calmant. In: Nouvelles et Textes pour rien. Paris: Les Éditions de Minuit, 1958 , p. 44. "Sim, esta noite tem de ser como no conto que meu pai costumava ler para mim, noite após noite. quando eu era pequeno, e ele tinha boa saúde, para me acalmar, noite após noite, durante anos, me parece esta noite, e do qual não guardei grande coisa, a não ser que se tratava das aventuras de um tal de Joe Breem, ou Breen, filho de um faroleiro, rapaz de quinze anos, forte e musculoso, é a frase exata, que nadou milhas, de noite, com uma faca entre os dentes, perseguindo um tubarão, já não sei por quê, por simples heroísmo. Ele poderia simplesmente ter-me contado a história, ele a sabia de cor, eu também, mas isso não me teria acalmado, tinha de lê-la para mim, noite após noite, ou fingir que a lia para mim, virando as páginas e me explicando as figuras, que já eram parte de mim, noite após noite as mesmas figuras, até que eu adormecesse em seu ombro". (Beckett, S. O calmante. In: Novelas. São Paulo: Martins Fontes, 2006, p. 31) 
tout" $^{\prime 199}$. Na peça radiofônica Embers, o protagonista Henry também tem o hábito de contar uma história a si mesmo. Trata-se da história de Bolton e Holloway. O primeiro personagem recebe o segundo em uma noite de inverno e apesar da história nunca ser finalizada por Henry, a visita de Holloway tem a ver com o desejo que Bolton tem de morrer e a ajuda que o amigo, um médico, poderia oferecer.

Esses personagens parecem encontrar na ficção a companhia que rejeitam em seus semelhantes. Em toda prosa de Beckett, desde Murphy, é notável a predileção dos protagonistas pelo isolamento social. Mesmo quando existe a possibilidade de contato ou amizade, o personagem opta por se isolar. Murphy, por exemplo, identifica-se e começa uma amizade com o Sr. Endon, paciente de um hospital psiquiátrico que tem por hábito jogar xadrez sozinho, ou seja, há uma espécie de espelhamento entre os dois. A própria estrutura do romance Murphy gira em torno de uma série de personagens que perseguem o protagonista sem conseguir encontrá-lo. A fuga dos laços com essas pessoas direciona Murphy ao isolamento. $O$ protagonista de Premier Amour oscila entre a vontade de estar com Lulu e o desejo de voltar às ruas e, ao final da novela, opta por retomar a vida andarilha e solitária. Molloy e Malone encontram-se isolados em seus quartos contando suas histórias. Nas novelas, o narrador está sempre fugindo daqueles que buscam ajudá-lo e sentese, inclusive, incomodado com a generosidade alheia. Além da necessidade de isolamento, o desconforto também se relaciona com a dificuldade em comunicar-se. Em L'expulsé, o narrador salienta a incomunicabilidade existente entre ele e o cocheiro que o guia pela cidade:

199 Beckett, S. Malone Meurt. Paris: Les Éditions de Minuit, 2004, p. 8. "Enquanto espero, vou tentar me contar histórias, se puder. Não o mesmo tipo de histórias que antigamente, sem dúvida. (Beckett, S. Malone Morre. Trad. Paulo Leminski. São Paulo: Códex, 2004, p. 10) 
Je lui décrivis ma situation, ce que j'avais perdu et ce que je cherchais. Nous faisions notre possible tous les deux, pour comprendre, pour expliquer. Il comprenait que j'avais perdu ma chambre et qu'il m'en fallait une autre, mais tout le reste lui échappait ${ }^{200}$.

Em Le calmant, o protagonista envergonha-se ao tentar, sem sucesso, conversar com um menino: "Je préparai donc ma phrase et ouvris la bouche, croyant que j'allais l'entendre, mais je n'entendis qu'une sorte de râle, inintelligible même pour moi qui connaissais mes intentions"201.

O tema da linguagem falha aparece nessas histórias e intensifica-se na prosa final do autor. Há um progressivo abandono das tentativas de relação com os outros e um movimento para dentro de si. $O$ ato de narrar, contudo, adquire grande importância nesse mundo solipsista pois passa a ser, justamente, a única companhia possível.

Em Ohio Improptu, o personagem do leitor encarna uma função semelhante à da voz de Company. A função do "enviado do ente querido" é ler a um outro passagens significativas da vida deste contidas em um livro. Os trechos evocam os momentos vividos por ele e este ente querido, sendo este último o responsável por enviá-lo o leitor. Novamente aqui temos essa "cadeia" em torno da narração. Além disso, a peça dramatiza a situação da leitura chamando a atenção para seu caráter de companhia. Também o tema do livro que

\footnotetext{
200 Beckett, S. L'expulsé. In: Nouvelles et Textes pour rien. Paris: Les Éditions de Minuit, 1958, p. 30. "Descrevi minha situação, o que tinha perdido e o que procurava. Fazíamos o possível, ambos, para compreender, para explicar. Ele compreendeu que eu perdera meu quarto e precisava de outro, mas todo o resto Ihe escapou". (Beckett, S. O expulso. In: Novelas. Trad. Eloísa Araújo Ribeiro. São Paulo: Martins Fontes, 2006, p. 18-9)

${ }^{201}$ Beckett, S. Le calmant. In: Nouvelles et Textes pour rien. Paris: Les Éditions de Minuit, 1958, p. 49-50. "Preparei portanto minha frase e abri a boca, achando que a ouviria, mas ouvi apenas uma espécie de chiado, ininteligível até mesmo para mim, que sabia quais eram as minhas intenções". (Beckett, S. O calmante. In: Novelas. Trad. Eloísa Araújo Ribeiro. São Paulo: Martins Fontes, 2006, p. 35).
} 
é lido tem a ver com a companhia que estes dois sujeitos se fizeram

- "alone together so much shared" - agora substituída pela leitura:

One night as he sat trembling head in hands from head to foot a man appeared to him and said, I have been sent by - and here he named the dear name - to comfort you. Then drawing a worn volume from the pocket of his long black coat he sat and read till dawn. Then disappeared without a word. ${ }^{202}$

A leitura e a narrativa confortam o personagem beckettiano. $\mathrm{Na}$ prosa, as histórias apontam para uma dificuldade cada vez mais intensa com o ato de narrar, por um questionamento da linguagem e das formas de representação, entretanto, elas são indispensáveis para o narrador beckettiano, independentemente da configuração que adquirem. É a história de Joe Breen que faz o menino de "Le calmant" adormecer. A voz que chega ao sujeito de Company também pode ter um caráter apaziguador, como se o personagem ali deitado estivesse ouvindo aqueles fragmentos de história antes de adormecer para sempre, uma última berceuse que, no mundo beckettiano, nunca é a última. A existência do sujeito está ligada à escuta da voz. Esta dependência também aparece em outras obras, como veremos a seguir. Ao mesmo tempo em que parece apaziguar, a voz mantém o ouvinte prisioneiro daquela contação de histórias.

A aliança entre fiç̧ão e companhia também se vale de elementos autobiográficos identificáveis em ambas as obras. Assim

202 Beckett, Samuel. Ohio Improptu. In : Samuel Beckett. The complete dramatic works. London: Faber \& Faber, p. 447. "Uma noite quando ele sentou com a cabeça trêmula nas mãos da cabeça aos pés um homem apareceu a ele e disse - fui enviado por - e aqui ele nomeou o nome querido - para confortá-lo. Então retirando um gasto volume do bolso de seu longo casaco preto ele sentou e leu até o amanhecer. Depois desapareceu sem uma palavra". 
como as cenas apresentadas pela voz em Company, também a forte amizade descrita em Ohio Improptu refere-se a um momento, devidamente ficcionalizado, da vida do autor. Os passeios pelo Quartier Latin em Paris são entendidos pela crítica beckettiana como uma referência aos passeios que ele costumava fazer na cidade com James Joyce, na ocasião em que ambos estavam na França. Também é sabido que Beckett lia para Joyce quando este começou a perder a visão, cena que a peça também evoca. A imagem do sujeito que presta atenção na leitura valendo-se apenas da audição assemelha-se à do indivíduo de Company ${ }^{203}$.

Longe de tentar fazer um uso inocente da biografia de Beckett, buscando correspondências imediatas entre vida e obra, é interessante observar as formas criadas pelo autor para ficcionalizar o real. O próprio conceito de "realidade" é posto à prova nestes textos finais, daí o destaque para os órgãos da percepção humana. Se nossa própria percepção é falha e se a linguagem falseia o mundo, a saída encontrada por Beckett foi trazer esses temas para o centro de sua ficção final, questionando fortemente o papel da linguagem - afinal, o que é real e o que é ficção? Há diferença entre eles? Ou nas palavras do narrador de Mal Vu Mal Dit - "Já que na verdade real e - como dizer o contrário?... Não importa. Nada mais importa. Já que na verdade ambos são mentiras. Real e - como mal dizer o contrário? 0 contra-veneno" ${ }^{204}$. A ideia que se tem aqui é a de que o antídoto para a mentira do real é justamente a fiç̧ão.

A utilização de material autobiográfico nessas obras está a serviço do esfumaçamento entre as fronteiras do real e da ficção ambas fantasiosas. É claro que Beckett não é o primeiro escritor a trabalhar nesse limite. Recentemente diversos escritores têm

203 Há uma diferença considerável, porém, entre as atitudes dos ouvintes das duas obras. A inércia do ouvinte de Company não está presente em Ohio Improptu. Nesta peça, apesar de não usar palavras, o ouvinte se manifesta através do ato de bater na mesa.

${ }^{204}$ Beckett, S. Mal Visto Mal Dito, p. 56. 
trabalhado no limiar entre ficção e biografia, cunhando tanto novas formas narrativas como duplos ou alter-egos de si próprios. É o caso de Enrique Vila- Matas em Dublinesca, de Philip Roth e seu Nathan Zuckerman, das falsas biografias de J.M. Coetzee e das narrativas do escritor alemão W.G. Sebald, apenas para mencionar alguns romancistas contemporâneos.

O traço distintivo de Beckett, entretanto, é a abordagem radical e fragmentada desse tipo de experiência pessoal, incrementada também pela sua atividade de dramaturgo. Há uma proximidade entre obras como Company, Ohio Improptu, That Time e inclusive Krapp's Last Tape. Apesar de mais distante temporalmente das anteriores, toda a ação de Krapp está voltada para a escuta de suas fitas, antecipando o papel essencial que essa atividade terá em Company.

A contaminação mútua entre prosa e teatro é muito presente nesta fase final da obra de Beckett. Além dos temas comuns, há ainda um tensionamento dos gêneros trabalhados. Se a mulher de Rockaby nos lembra da personagem de Mal Vu Mal Dit, a linguagem desta peça também se assemelha a um poema. Também aqui, temos mais uma vez o destaque dado à escuta. A atenção do espectador de uma peça como essa pende muito para a sonoridade do que é dito, da mesma forma com a qual precisamos ler um poema em voz alta para captar os jogos entre as palavras, a cadência e o ritmo que se estabelecem pela escolha do autor: "till in the end/ the day came/in the end came/ close of a long day/ when she said/to herself/ whom else ..."205

A ação da peça é mínima, restringindo-se ao movimento da cadeira e ao abrir e fechar de olhos da mulher. Mas ao contrário do passivo ouvinte de Company e mais próxima do ouvinte de Ohio

\footnotetext{
${ }^{205}$ Beckett, S. "Rockaby". In : The complete dramatic works, op. cit., p. 435. "até que no fim/ o dia veio/no fim veio/no fim de um longo dia/quando ela disse/ para ela mesma/ para quem mais...".
} 
Improptu, a mulher de Rockaby solicita a continuidade da voz gravada através de seus pedidos - "More". A voz se associa ao movimento da cadeira de balanço e estará presente até os minutos finais da vida da protagonista. Mais uma vez aqui, a voz é companhia, mas também dependência. A existência da mulher está ligada à escuta daquela gravação.

Além de cindir a narração, o recurso à voz também cinde o próprio sujeito dessas histórias. A voz exterioriza algo muito próprio desses protagonistas - seus momentos de vida. No entanto, esses momentos nunca estão na boca deles próprios. É a mesma dificuldade que a protagonista de Not I tem em dizer "eu", ainda que nas fitas de Krapp e na gravação de Rockaby estejam as próprias vozes dos personagens.

A fragmentação do universo final beckettiano reforça a ideia desse sujeito cindido. É interessante notar como a voz ganha corpo no decorrer da obra do autor, tornando-se uma instância muito presente. A configuração dada a ela em Company aproxima-se mais das peças mencionadas - That Time, Rockaby - do que dos textos em prosa anteriores nos quais o mesmo recurso é utilizado L'innommable, Textes pour rien, Comment C'est. Sua utilização mais "teatralizada" é fundamental para marcar essa ruptura do sujeito. A voz refere-se a ele, mas ao mesmo tempo está fora dele. Mesmo em Ohio Improptu, a leitura daqueles momentos de vida é realizada por um outro, ainda que fortemente associado àquele que ouve, pela semelhança física e vestuário comuns.

A cisão do sujeito está sempre em evidência. Talvez esse seja um dos motivos pelos quais o ouvinte de Company não consiga pronunciar o "Sim, eu me lembro" e confirmar que aquelas cenas narradas fizeram parte de sua história de vida. Se pensarmos ainda que as cenas trazidas pela voz referem-se à vida do próprio Beckett vemos que as fronteiras entre ficção e biografia receberam um 
tratamento muito original em sua prosa, marcando fortemente a fragmentação do indivíduo e de sua história de vida. Ao contrário dos autores citados anteriormente, nos quais vida e obra se misturam no universo ficcionalizado do romance, em Beckett o que se destaca é a solução formal escolhida para trabalhar com esses temas - a aliança entre cisão narrativa, recursos cênicos, mescla de gêneros e metaficção.

Além das histórias em si, o destaque para a escuta em Company e para a visão em Mal Vu Mal Dit ressaltam a discussão já levantada em torno da percepção humana. A capacidade de criar e representar é posta em pauta também em Worstward Ho através da atividade intensa da mente que vê imagens e tenta configurar uma narrativa. A prosa final recua e configura a origem da criação artística.

Apesar de sempre constatar a falha - seja na percepção humana, na linguagem ou no próprio narrar - deixar de escrever, de fazer ficção, nunca foi uma opção para Beckett. Esses temas tornaram-se seu próprio material.

A voz vem dar forma original a uma divisão que já havia brotado na prosa de Beckett, tanto do ponto de vista narrativo como daquele que aponta para a cisão do indivíduo. No drama, é só pensarmos na cabeça e na boca soltas no espaço em That Time e Not I. Não se trata de um mero recurso cênico, nem nas peças mencionadas nem na utilização da voz em Company. A escolha do olho como parceiro do narrador de Mal Vu Mal Dit cumpre uma função semelhante abrindo mais um caminho para que a tentativa de narrar uma história se realize. No entanto, da mesma forma com a qual o narrador em primeira-pessoa se questionava sobre a história que contava, as questões levantadas pelos narradores dessas duas últimas obras colocam mais uma vez sob suspeita as novas 
configurações escolhidas, marca de uma obra que nunca deixou de se questionar.

\title{
3.3 "Confusão também é companhia até certo ponto"
}

\author{
O penúltimo parágrafo de Company, imediatamente anterior ao \\ "sozinho" isolado que encerra a obra apresenta um desfecho \\ sugerindo uma conexão entre o ouvinte, o criador/escritor e até \\ mesmo o leitor. É o momento no qual essas figuras parecem se unir \\ e terminamos com: "E você como você sempre esteve. Sozinho". O \\ trecho decisivo é:
}

[...] From time to time with unexpected grace you lie. Simultaneously the various parts set out. The arms unclasp the knees. The head lifts. The legs start to straighten. The trunk tilts backwards. And together these and countless others continue on their respective ways till they can go no further and together come to rest. Supine now you resume your fable where the act of lying cut it short. And persists till the converse operation cuts it short again. So in the dark now huddled and now supine you toil in vain. And just as from the former position to the latter the shift grows easier in time and more alacritous so from the latter to the former the reverse is true. Till from the occasional relief it was supineness becomes habitual and finally the rule. You now on your back in the dark shall not rise to your arse again to clasp your legs in your arms and bow down your head till it can bow down no further. But with face upturned for good labour in vain at your fable. Till finally you hear how words are coming to an end. With every inane word a little nearer to the last. And how the fable too. The fable of one with you in the dark. The fable of one fabling of one with you in the dark. And how better in the end labour lost and silence. And you as you always were.

Alone ${ }^{206}$.

206 Beckett, S. Company, p. 449-50. "De tempos em tempos com uma graça inesperada você se deita. Simultaneamente as várias partes se separam. Os braços desapertam os joelhos. A cabeça se ergue. As pernas começam a se esticar. $O$ tronco pende para trás. E juntas essas e inúmeras outras continuam nos seus respectivos caminhos até não poderem ir mais longe e juntas repousam. De costas agora você retoma sua fábula onde o ato de deitar-se a interrompeu. E persiste até 
Depois de acompanharmos o jogo entre narrador e voz ao longo da obra, o que temos aqui é o que parece ser uma última manifestação da voz. Após trazer os fragmentos de vida do sujeito, ela agora ressalta sua condição atual de homem deitado no escuro. Ela descreve o movimento do sujeito se deitando e assumindo a postura com a qual ele inicia a obra. É nessa posição que ele vai "trabalhar em vão na sua fábula", a fábula que acabamos de ler, ou seja, o ouvinte seria o próprio autor da narrativa. Na sequência, temos - "a fábula de alguém com você no escuro" - seria essa uma referência ao criador que rasteja? A leitura nos leva a crer que sim. Logo depois, temos "a fábula de alguém fabulando de alguém com você no escuro". Acredito que aqui teríamos chegado à figura do próprio escritor que fabula sobre o criador e o ouvinte. No entanto, o trecho destacado anteriormente sugere que quem fabula é o ouvinte. Após a separação dessas instâncias, teríamos agora uma junção. A confusão é proposital e não se apreende facilmente do texto, mas a sugestão é evidente.

A ideia de definir mais precisamente a figura deste criador, entendido como uma manifestação do escritor em sua obra ,aparece pela primeira vez no parágrafo 31 :

In the same dark as his creature or in another not yet imagined. Nor in what position Whether standing or sitting or lying or in some other position in the dark. There are among the matters yet to be imagined. Matters of which as yet no inkling. The test is company.

que a operação inversa a interrompa de novo. Assim no escuro ora acocorado ora de costas você labuta em vão. E exatamente como da primeira posição para a segunda a mudança se torna cada vez mais fácil com o tempo e mais lépida da segunda para a primeira o contrário é verdade. Até que o alívio ocasional que era deitar-se se torna habitual e finalmente a regra. Você agora deitado de costas no escuro não irá erguer-se de novo para apertar as pernas com os braços e abaixar a cabeça até não poder abaixá-la mais. Mas com o rosto voltado para cima de vez trabalhar em vão na sua fábula. Até finalmente ouvir como as palavras estão chegando ao fim. Com cada palavra inane um pouco mais perto da última. E como a fábula também. A fábula de alguém com você no escuro. A fábula de alguém fabulando de alguém com você no escuro. E como melhor no fim trabalho perdido e silêncio. E você como você sempre esteve.

Sozinho. (Beckett, S. Companhia, p. 62-3) 
Which of the two darks is the better company. Which of all imaginable positions has the most to offer in the way of company. And similarly for the other matters yet to be imagined. Such as if such decisions irreversible. Let him for example after due imagination decide in favour of the supine position or prone and this in practice prove less companionable than anticipated. May he then or may he not replace it by another? Such as huddled with his legs drawn up within the semicircle of his arms and his head on his knees. Or in motion. Crawling on all fours. Another in another dark or in the same crawling on all fours devising it all for company. Or some other form of motion. The possible encounters. A dead rat. What an addition to company that would be! A rat long dead ${ }^{207}$.

A configuração imaginada para o criador sempre se refere à sua posição e aos movimentos que ele pode executar. Enquanto o ouvinte é passivo e permanece na posição de costas no escuro, apenas como um receptor das histórias, o criador se move e rasteja na escuridão ${ }^{208}$. A ideia do rastejamento sugere uma busca, uma tentativa de sair do lugar e encontrar algo, ainda que seja a melhor posição para se ficar. A associação imediata que podemos fazer seria com uma busca pela obra, pela forma de contar essa história. No parágrafo 52, entretanto, há uma reflexão sobre a possibilidade do criador criar enquanto rasteja ao que o narrador conclui negativamente: "Crawling in the dark in the way described was too

\footnotetext{
207 Company, p. 435. "No mesmo escuro que a sua criatura ou num outro ainda não imaginado. Nem em qual posição. Se em pé ou sentado ou deitado ou em alguma outra posição no escuro. Estes estão entre os assuntos ainda a ser imaginados. Assuntos dos quais até agora nenhum esboço. O teste é companhia. Qual dos dois escuros é melhor companhia. Qual de todas as posições imagináveis tem mais a oferecer quanto a companhia. E similarmente para os outros assuntos ainda a ser imaginados. Tais como se tais decisões irreversíveis. Que decida por exemplo depois da devida imaginação a favor da posição de costas ou de bruços e isso na prática prove ser menos propenso a companhia que o antecipado. Ele pode ou não pode substituí-la por outra? Como acocorado com as pernas puxadas para dentro do semicírculo dos braços e a cabeça nos joelhos. Ou em movimento. Rastejando de quatro. Um outro num outro escuro ou no mesmo rastejando de quatro inventando isso tudo por companhia. Ou alguma outra forma de movimento. Os encontros possíveis. Um rato morto. Que acréscimo a companhia isso ia ser! Um rato morto há tempo. (Companhia, p. 39-40)

${ }^{208}$ A descrição do rastejamento do criador aparece nos parágrafos 49 e 50.
} 
serious a matter and too all-engrossing to permit of any other business were it only the conjuring of something out of nothing" 209 .

Teríamos, assim, um criador incapaz de criar colocado em cena ao lado do imóvel ouvinte. A situação traz novamente a ideia de impasse. Ao chegarmos ao parágrafo 54 vemos que, cansado de rastejar, o criador busca a melhor forma para se deitar e anseia pela presença da voz, que continua soberana na escuridão:

[...] For little by little as he lies the craving for company revives. In which to escape from his own. The need to hear that voice again. If only saying again, You are on your back in the dark. Or if only, You first saw the light and cried at the close of the day when in darkness Christ at the ninth hour cried and died. The need eyes closes the better to hear to see that glimmer shed. Or with addition of some human weakness to improve the hearer. For example an itch beyond reach of the hand or better still within while the hand immovable. An unscratchable itch. What an addition to company that would be! Or last if not least resort to ask himself what precisely he means when he speaks of himself loosely as lying $[\ldots]^{210}$.

Nesse trecho, ao colocar o criador sentindo a falta da manifestação da voz, acabamos associando sua figura à do ouvinte. Ao mesmo tempo, quando ele menciona a possibilidade de melhorar o ouvinte ou se questiona sobre sua posição dizendo que "fala de si mesmo imprecisamente como deitado" associamo-lo à figura do escritor, que se divide e dialoga consigo mesmo através da figura deste criador.

${ }^{209}$ Company, p. 446. "Rastejar no escuro da maneira descrita era uma coisa séria demais e totalmente absorvente demais para admitir qualquer outra ocupação nem que fosse só a de conjurar algo do nada". (Companhia, p. 56)

210 Company, p. 447. "Pois pouco a pouco enquanto está deitado a ânsia por companhia se reaviva. Na qual escapar da sua própria. A necessidade de ouvir aquela voz de novo. Que seja apenas a dizer de novo, Você está deitado de costas no escuro. Ou apenas, Você viu a luz primeiro e gritou no fim do dia em que na escuridão Cristo na nona hora gritou e morreu. A necessidade olhos fechados para melhor ouvir de ver aquele lampejo emitido. Ou com a adjunção de alguma fraqueza humana melhorar o ouvinte. Por exemplo uma coceira fora do alcance da mão ou melhor ainda dentro mas a mão inerte. Uma coceira incoçável. Que acréscimo a companhia isso ia ser! Ou como último senão máximo recurso perguntar-se o que exatamente ele quer dizer quando fala de si mesmo imprecisamente como deitado" (Companhia, p. 58) 
Nesses últimos parágrafos de Company, parece haver uma preparação para a fusão sugerida no penúltimo parágrafo. Voltando a este bloco (parágrafo 58 acima citado), podemos notar que a narração ressalta a movimentação do ouvinte até que ele assuma a postura de costas no escuro. Neste momento, acabamos lembrando também das movimentações do criador em sua tentativa de se deitar, descritas nos parágrafos anteriores. As passagens finais encaminham-se no sentido de embaralhar as figuras na cabeça do leitor. O trecho "De costas agora você retoma sua fábula onde o ato de deitar-se a interrompeu. E persiste até que a operação inversa a interrompa de novo. Assim no escuro ora acocorado ora de costas você labuta em vão" é um exemplo desse esfumaçamento, já que a posição acocorada e $o$ ato de deitar-se foram usados anteriormente em relação ao criador, mas a frase se refere ao ouvinte.

A expressão "em vão" e o trecho "E como melhor no fim trabalho perdido e silêncio" indicam mais uma vez a insatisfação com o que se narrou. As frases que fecham a obra - "E você como você sempre esteve. Sozinho" - trazem aquela sensação gerada pelo terceiro parágrafo no momento da definição das características da voz - "O uso da segunda-pessoa marca a voz. O da terceira aquele outro pustulento. Se ele pudesse falar para e de quem a voz fala haveria uma primeira. Mas ele não pode. Ele não vai. Você não pode. Você não vai"211.

O uso do pronome você atinge o ouvinte e o leitor. É como se nesse final o texto também evocasse a própria imagem do sujeito que, sozinho, lê a obra. Haveria, dessa forma, uma referência ao próprio ato da leitura como fonte de companhia. A palavra "sozinho" em destaque acaba reforçando o papel da imaginação, da fantasia, e da própria literatura. Elas tornam o sujeito menos sozinho do que 0 peso da palavra isolada no texto faz parecer. A obra encerra-se com

${ }^{211}$ Idem, p. 28 
essa ambiguidade. Há uma referência à solidão do sujeito aliada a tudo que sua própria imaginação pode criar para fornecer-lhe companhia.

\subsection{Conciliação ou novo impasse?}

Dentro do universo da prosa final de Beckett, Company pode ser considerada uma das obras mais acessíveis. Escritores contemporâneos conhecidos por serem grandes admiradores de Beckett, como Paul Auster e J.M. Coetzee, já declararam que a prosa final do autor não é o período do qual mais gostam. Auster, contudo, cita justamente Company como uma exceção à regra ${ }^{212}$.

A predileção pela obra pode estar ligada a essa acessibilidade e à mescla de narrações sobre a qual a obra se estrutura. Company se move em um terreno entre a narrativa tradicional e a fragmentação característica de Beckett. Se a compararmos com Ill Seen IIl Said, Worstward Ho ou mesmo Stirrings Still veremos que, ao contrário das outras três, os fragmentos de história trazidos pela voz acabam dando a impressão de que, em Company, Beckett volta a "contar uma história", o que poderia sugerir uma conciliação com o ato de narrar. Isso se deve à utilização do narrador-voz. Suas manifestações trazem ecos de um mundo distante da prosa final do autor. Tal

\footnotetext{
212 Refiro-me a uma declaração de Auster em um evento de maio de 2013, em Nova York, no qual o escritor e o dramaturgo Edward Albee discutem a obra de Beckett. Auster cita Company como uma das obras "menos duras" da prosa final do autor e demonstra apreço por ela. (Ver Edward Albee and Paul Auster Discuss Samuel Beckett. A public event recorded at New York's Strand Books, disponível no site www.apieceofmonologue.com). Já Coetzee declara em entrevista que a prosa final de Beckett é muito desencarnada e nunca captou muito a sua atenção (Ver Attwell, David (Ed) Doubling the Point. Essays and Interviews/ J.M. Coetzee. Cambridge/Massachusetts; London/England: Harvard University Press, 1992, p. 23)
} 
recurso, entretanto, não foi escolhido de forma ingênua por um escritor tão atento e cuidadoso e não significa uma mera volta ao passado. Beckett parece trazer, novamente, para o centro da roda, a discussão sobre de que forma continuar fazendo literatura. A aparente recuperação das formas vem imersa em um jogo narrativo que se questiona intensamente.

Vimos que, desde cedo, Beckett se orientou pelo projeto da falha. Em IIl Seen IIl Said e Worstward Ho o ataque à palavra e à capacidade de representação literária é mais explícito. Na primeira obra, temos a imagem que se esfumaça, as dificuldades do olho em absorver o que vê, as perguntas do narrador; na segunda, o próprio jogo linguístico com a materialidade da palavra, de forma a piorá-la e chegar ao que estaria por trás dela, mas como se daria o projeto da falha em Company?

Vejamos o seguinte trecho:

Impending for some time the following. Need for company not continuous. Moments when his own unrelieved a relief. Intrusion of voice at such. Similarly image of hearer. Similarly his own. Regret then at having brought them about and problem how dispel then. Finally what meant by his own unrelieved? What possible relief? Leave it at that for the moment ${ }^{213}$.

Este parágrafo (34) localiza-se logo após o trecho referente ao ouriço e questiona a necessidade da ficção como companhia, chamando a atenção para a companhia que o próprio sujeito pode oferecer a si mesmo - "Necessidade de companhia não contínua. Momentos quando a sua própria sem alívio um alívio". A companhia que, sem alívio é alívio, forma uma contradição, demonstra esse

213 Company, p. 437. "Iminente há algum tempo o seguinte. Necessidade de companhia não contínua. Momentos quando a sua própria sem alívio um alívio. Intrusão da voz nesses. Similarmente imagem do ouvinte. Similarmente a sua própria. Arrependimento então de tê-las suscitado e problema como dispersá-las. Finalmente o que significa a sua própria sem alívio? Que alívio possível? Deixar assim por enquanto". (Companhia, p. 42) 
"entre-lugar" no qual o narrador se encontra e configura, mais uma vez, um impasse. Em um trecho citado anteriormente, o narrador deseja uma "coceira incoçável" para o ouvinte. Mais uma vez, há essa ideia de paralisia, cria-se uma imagem que traduz um impasse. 0 trecho também parece reforçar a ideia de dependência da narrativa que observamos em outras obras. Sua própria companhia não lhe é suficiente. É preciso ficcionalizá-la, tematizá-la. Paralelamente, o narrador arrepende-se de ter suscitado a própria imagem e a do ouvinte, ou seja, de ter dado início à sua fiç̧ão. É nesse beco sem saída em que se encontra o narrador que a obra se constrói.

O projeto da falha se apresenta em Company através dessa incapacidade de completude do narrador, da ambiguidade que permeia a obra, da incapacidade do ouvinte em acolher as manifestações da voz e dar-lhe credibilidade, do caráter fluido do texto. "Deixar assim por enquanto" encerra o trecho. Nada é conclusivo. A capacidade da obra em fornecer companhia, entretanto, continua válida e em Company, o tema é alçado ao primeiro plano. A ficção é, certamente, companhia, mas uma companhia extremamente conflituosa nas mãos de um autor que sempre duvidou da linguagem e de sua capacidade de comunicar.

Em Company, encontramos a configuração mais acabada de um processo que permeia toda a prosa de Beckett - a tematização da necessidade da ficção apesar de todas as desconfianças que a linguagem pode suscitar. A duplicidade que se estabelece entre narrador e voz é a própria problematização deste grande tema - um confronto entre a tentativa de articular uma história e a impossibilidade de fazê-lo. É no processo de tentar que o narrador beckettiano cria e se sustenta. 
A prosa final de Beckett chama a atenção para o ato de narrar como fonte de companhia e também como uma obsessão. Fail again. Fail better. É através do questionamento em torno da linguagem e da percepção humana que se busca acessar algum significado ou criar outras formas de comunicação. Para isso, é necessário "descascar" a gasta palavra, empregá-la de novas formas e atacar conhecidas formas de narrar em busca de algo novo. Desde as novelas em francês, o processo do narrador beckettiano está centrado nesta tentativa. Company, III Seen III Said e Worstward Ho são três configurações distintas criadas para apresentar os problemas de representação literária que este narrador enfrenta.

Company se destaca nesta fase pois, através de sua duplicidade narrativa, deixa bastante aparente a luta entre uma história de vida que tenta se formar e ser narrada e a resistência em acolhê-la. A voz que chega ao sujeito no escuro incomoda, pois tenta convencê-lo a reconstruir sua memória espelhando a tentativa do escritor em compor uma obra de forma inteligível, valendo-se de uma linguagem mais próxima do cotidiano. A organização e a recuperação da memória sempre foram um dos temas centrais do romance, proporcionando a composição de uma história de vida e a busca por um significado a partir dela. Tal intenção não pode ser concretizada no mundo beckettiano cujo cerne está justamente em colocar em xeque esta possibilidade. Restos de memória compartilhados entre os personagens perpassam diversos trabalhos do autor e nunca chegam a uma configuração coesa, não fornecem a ideia de totalidade, nem de sentido. Surgem para atormentar o sujeito, para reforçar o caráter fragmentário dessas lembranças e da própria experiência vivida.

A voz que chega a alguém no escuro também representa a própria voz da imaginação que impele o artista a criar. Seu aspecto positivo é possibilitar a criação literária, o "seguir adiante". Seu lado 
negativo está no tom autoritário, naquilo que "vem de cima" e tortura o sujeito, obriga-o a ouvir, a "seguir adiante", torna-o prisioneiro do ato de narrar.

Solidão, memória e angústia, temas que atravessam toda a obra de Beckett, recebem um tratamento muito inovador e também perturbador na prosa final do autor, especialmente em Company que, por conta da ideia da ficção como companhia, pode dar a impressão da literatura como algo reconfortante para o sujeito beckettiano. Como pudemos observar, esta ideia não é dispensada, mas surge para ser questionada.

O narrador está em trânsito permanente, sempre reconfigurando suas narrativas. Sua trajetória é marcada por essa disponibilidade incessante, motor da prosa beckettiana, que se constrói através de suas próprias ruínas. O ataque à linguagem, as dúvidas, o hermetismo e a fragmentação das histórias apontam para a impossibilidade de narrar. Em alguns momentos, a própria comunicação com o leitor parece ruir, caso de Worstward Ho, texto no qual o ato de revirar a palavra constantemente, voltar, seguir, desconstruir, desconcentra o leitor, deixa a leitura por um fio. No entanto, mesmo em uma obra radical como essa, percebemos que o narrador está em busca de algo, ele persiste e luta com a linguagem. Seu objetivo não é apenas arrasar e destruir.

Os restos de memória que chegam ao ouvinte em Company indicam que a acessibilidade a uma história de vida através da escrita não foi totalmente rompida, mas de que forma narrá-la? Usando a linguagem que o narrador tanto despreza? Ele nunca chega a um consenso, configura seus próprios questionamentos em obra literária. Sua busca não se conclui. O aprisionamento no interior da mente é o destino final do narrador beckettiano. Ali, a imaginação, a palavra e as vozes voltam a enfrentar-se. Revolving it all. 


\section{BIBLIOGRAFIA}

\section{1) Bibliografia do autor}

BECKETT, S. Samuel Beckett. The Grove Centenary Edition. Volume I. Novels. New York: Grove Press, 2006.

. Samuel Beckett. The Grove Centenary Edition. Volume IV. Poems, Short Fiction, Criticism. New York: Grove Press, 2006.

- Samuel Beckett. The Complete Dramatic Works. London: Faber \& Faber, 2006.

- Comment C'est. Paris: Les Éditions de Minuit, 1999.

. Como é. Trad. Ana Helena Souza. São Paulo:

Iluminuras, 2003.

. Companhia e outros textos. Trad. Ana Helena Souza. São Paulo: Globo, 2012.

- Dias Felizes. Trad. Fábio de Souza Andrade. São Paulo: Cosac Naify, 2010.

- Disjecta. Miscellaneous Writings and a Dramatic Fragment. New York: Grove Press, 1984.

. Dream of fair to middling women. Edited by Eoin O'Brien and Edith Fournier. New York: Arcade Pub. in association with Riverrun Press, 1993.

. Esperando Godot. Trad. Fábio de Souza Andrade.

São Paulo: Cosac Naify, 2005.

. Fim de partida. Trad. Fábio de Souza Andrade. São

Paulo: Cosac Naify, 2002.

. Le dépeupleur. Paris: Les Éditions de Minuit, 1970. 
. L'innommable. Paris: Les Éditions de Minuit, 2004. . O inominável. Trad. Ana Helena Souza. São Paulo:

Globo, 2009.

. O Despovoador/Mal Visto Mal Dito. Trad. Eloísa Araújo Ribeiro. São Paulo: Martins Fontes, 2008.

- Mal Vu Mal Dit. Paris: Les Éditions de Minuit, 1983.

- Malone Meurt. Paris: Les Éditions de Minuit, 2004.

. Malone Morre. Trad. Paulo Leminski. São Paulo:

Códex, 2004.

. Molloy. Paris: Les Éditions de Minuit, 1982.

- Molloy. Trad. Ana Helena Souza. São Paulo:

Globo, 2007.

- Murphy. Trad. Fábio de Souza Andrade. São

Paulo: Cosac Naify, 2013.

. Nouvelles et Textes pour rien. Paris : Les Éditions de Minuit, 1958.

. Novelas. Trad. Eloísa Araújo Ribeiro. São Paulo: Martins Fontes, 2006.

- Premier Amour. Paris: Les Éditions de Minuit, 1970.

- Primeiro Amor. Trad. Célia Euvaldo. São Paulo: Cosac Naify, 2004.

. Proust. Trad. Arthur Nestrovski. São Paulo: Cosac Naify, 2003.

. Watt. Ed. Chris Ackerley. London: Faber \& Faber, 2009. 
- Watt. Trad. Manuel Resende. Lisboa: Assírio \&

Alvim, 2005.

\section{2) Bibliografia geral}

ACKERLEY, C.J. Demented Particulars. The Annotated Murphy. Edinburgh: Edinburgh University Press, 2010.

- Obscure Locks. Simple Keys. The Annotated Watt. Edinburgh: Edinburgh University Press, 2010. . The Uncertainty of Self: Samuel Beckett and the

Location of Voice. In: Uhlmann, Anthony, Houppermans, Sjef \& Clément, Bruno (Ed.). Samuel Beckett Today/Aujourd' hui. After Beckett. D'après Beckett. Amsterdam/New York: Rodopi, 2004.

ABBOTT, Porter, H. Beckett and Autobiography. In: FRIEDMAN, Alan W. ROSSMAN, Charles \& SHERZER, Dina (Ed.). Beckett Translating/Translating Beckett. Pennsylvania: Pennsylvania State University Press, 1987.

. Beckett Writing Beckett. The author in the autograph. Ithaca/London: Cornell University Press, 1996.

ADORNO, Theodor W. O artista como representante. In: Notas de Literatura. Trad. Jorge de Almeida. São Paulo: Editora 34, 2003. . Trying to understand Endgame. In: Notes to

Literature. Vol I. New York: Columbia University Press, 1991.

ANDRADE, Fábio de Souza. Samuel Beckett. O silêncio possível. São Paulo: Ateliê Editorial, 2001. 
- Try again. Fail again. Fail better. In:

Beckett, S. O despovoador/Mal Visto Mal Dito. Trad. Eloísa Araújo Ribeiro. São Paulo: Martins Fontes, 2008.

Facing other windows: Beckett in South

America. In: GONTARSKI, S.E. (Ed.) The Edinburgh Companion to Samuel Beckett and the Arts. Edinburgh: Edinburgh University Press, 2014.

ATTWELL, David (Ed) Doubling the Point. Essays and Interviews/ J.M. Coetzee. Cambridge/Massachusetts; London/England: Harvard University Press, 1992.

BADIOU, Alain. Beckett. L'incrévable désir. Paris: Hachette, 1995. . Ser, existência, pensamento: prosa e conceito. In: Pequeno manual de inestética. São Paulo: Estação Liberdade, 2002. BANFIELD, Ann. Mrs. Dalloway. In: MORETTI, Franco. A cultura do romance. Vol. I. Trad. Denise Bottmann. São Paulo: Cosac Naify, 2009.

BENETTI, Liliane. Ângulos de uma caminhada lenta: exercícios de contenção, reiteração e saturação na obra de Bruce Nauman. Tese apresentada ao Programa de Pós-Graduação em Artes Visuais da ECA/USP. São Paulo: 2013.

BERRETTINI, Célia. Samuel Beckett: Escritor Plural. São Paulo: Perspectiva, 2004.

BLANCHOT, Maurice. O livro por vir. Trad. Leyla Perrone- Moisés. São Paulo: Martins Fontes, 2005.

BOOTH, Wayne C. The Rhetoric of Fiction (Second Edition). Chicago: The University of Chicago Press, 1983.

BOXALL, Peter (Ed). Samuel Beckett. Waiting for Godot/Endgame. Cambridge: Icon Books Ltd., 2000. 
. Since Beckett. Contemporary Writing in the Wake of Modernism. London/New York: Continuum, 2009.

BRATER, Enoch. Beyond Minimalism. Beckett's late style in the theater. New York: Oxford University Press, 1987.

. The drama in the text. Beckett's late fiction. New

York: Oxford University Press, 1994.

. The Company Beckett Keeps: The Shape of Memory and One Fablist's Decay of Lying. In: Beja, Morris; Gontarski, S.E. \& Astier, Pierre (Ed). Samuel Beckett: Humanistic Perspectives. Ohio: Ohio State University Press, 1982.

.Voyelles, Cromlechs and the Special (W) rites of Worstward Ho. In: Acheson, James \& Arthur, Kateryna. Beckett's Later Fiction and Drama. Texts for Company. London: Macmillan Press, 1987

BRIENZA, Susan. Samuel Beckett's New Worlds. Style in Metafiction. Oklahoma: Oklahoma University Press, 1987.

BRYDEN, Mary; GARFORTH, Julian; MILLS, Peter. Beckett at Reading. Catalogue of the Beckett Manuscript Collection at The University of Reading. Reading: Whiteknights Press and the Beckett International Foundation, 1998.

CAMARGO, Robson Correa de. 50 Years of Beckett in the Brazilian Theatre. In: Journal of Beckett Studies, vol. 15, 2006.

CASANOVA, Pascale. Samuel Beckett. Anatomy of a Literary Revolution. London: Verso Books, 2006.

COHN, Dorrit. Transparent Minds. Narrative Modes for Presenting Consciousness in Fiction. Princeton, New Jersey: Princeton University Press, 1978. 
DAVIES, Paul. The Ideal Real. Beckett's Fiction and Imagination. London and Toronto: Associated Universities Presses, 1994.

DELEUZE, Gilles. Sobre o teatro: Um manifesto de menos; 0 esgotado. Trad. Fátima Saadi, Ovídio de Abreu, Roberto Machado. Rio de Janeiro: Jorge Zahar, 2010.

DIMANCHE, André (Ed). Samuel Beckett. Documents Sonores. Bry sur Marne, France: Institut National de I' Audiovisuel, 2007.

ESSLIN, Martin. O teatro do absurdo. Trad. Bárbara Heliodora. Rio de Janeiro: Zahar Editores, 1968.

- Samuel Beckett and The Art of Radio. In: GONTARSKI, S.E (Ed). On Beckett. Essays and Criticism. Londres: Anthem Press, 2014.

. Towards the zero of language. In: ACHESON, James

\& ARTHUR, Kateryna. Beckett's Later Fiction and Drama. Texts for Company. London: Macmillan Press, 1987.

FELDMAN, Matthew. Beckett's Books. A Cultural History of Samuel Beckett's Interwar Notes. New York/London: Continuum, 2006.

FINNEY, Brian. Still to Worstward Ho: Beckett's prose fiction since The Lost Ones. In: Acheson, James \& Arthur, Kateryna. Beckett's Later Fiction and Drama. Texts for Company. London: Macmillan Press, 1987.

FRIEDMAN, Alan W. ROSSMAN, Charles \& SHERZER, Dina (Ed.). Beckett Translating/Translating Beckett. Pennsylvania: Pennsylvania State University Press, 1987.

FROST, Everett C. 'The sound is enough'. Beckett's Radio Plays. In: GONTARSKI, S.E. (Ed). The Edinburgh Companion to Samuel Beckett and the Arts. Edinburgh: Edinburgh University Press, 2014. 
GONÇALVES, Lívia Bueloni. Um narrador no limite: O caminho da primeira-pessoa beckettiana das nouvelles aos Textes pour rien. Dissertação de mestrado. São Paulo: FFLCH/USP, 2009.

GONTARSKI, S.E. Company for Company: Androgyny and Theatricality in Samuel Beckett's prose. In: ACHESON, James \& ARTHUR, Kateryna. Beckett's Later Fiction and Drama. Texts for Company. London: Macmillan Press, 1987.

. The conjuring of something out of nothing:

Samuel Beckett's "closed spaces" novels. In: Beckett, S. Nohow on. Company, IIl seen IIl said, Worstward Ho. Three novels by Samuel Beckett with an Introduction of S.E. Gontarski. New York: Grove Press, 1996.

Beckett and the Unnamable Voice of (European) Modernism. In : Journal of Beckett Studies, vol. 13, number 2, Spring 2004.

GONTARSKI, S.E., FEHSENFELD, Martha, and MCMILLAN, Dougald. Interview with Rachel Burrows, Dublin, Bloomsday, 1982. In: Journal of Beckett Studies, n. 11 e 12, 1989, p. 6-15

GRAVER, Lawrence. Homage to the Dark Lady. Ill seen Ill Said. In: Ben-Zvi, Linda (Ed.) Women in Beckett: performance and critical perspectives. Illinois: University of Illinois Press, 1992.)

HULLE, Dirk Van \& NIXON, Mark. Samuel Beckett's Library. New York: Cambridge University Press, 2013.

JOHNS, Gregory. In the dim void. Samuel Beckett's Late Trilogy. Company, IIl Seen III Said and Worstward Ho. England: Crescent Moon Publishing, 1993.

JOYCE, James. Ulisses. Trad. Bernardina da Silveira Pinheiro. Rio de Janeiro: Alfaguara/Objetiva, 2007.

JULIET, Charles. Conversations with Samuel Beckett and Bram van Velde. Netherlands: Academic Press Leiden, 1995. 
KALB, Jonathan. The mediated Quixote: the radio and television plays, and Film. In: Pilling, John (Ed) The Cambridge Companion to Beckett. Cambridge: The Cambridge University Press, 1994.

. Beckett in performance. Cambridge: Cambridge University Press, 1989.

KNOWLSON, James. Damned to Fame. The Life of Samuel Beckett. New York: Grove Press, 1996.

. Light and Darkness in the Theatre of Samuel

Beckett. London: Turret Books, 1972.

KNOWLSON, James \& PILLING, John. Frescoes of the skull: the later prose and drama of Samuel Beckett. London: John Calder, 1979.

KRANCE, Charles. Samuel Beckett's Mal Vu Mal Dit/IIl Seen Ill Said. A Bilingual, Evolutionary, and Synoptic Variorum Edition. New York and London: Garland Publishing, Inc., 1996.

LE JUEZ, Brigitte. Beckett before Beckett. Samuel Beckett's lectures on French Literature. London: Souvenir Press, 2009.

LYDON, Mary. Beyond the criterion of genre: Samuel Beckett's Ars Poetica. In: ENGELBERTS, Matthijs (Ed.). Samuel Beckett Today/Aujourd'hui 8. Poetry and Other Prose/ Poésie et autres Proses. Amsterdam-Atlanta, GA: 1999.

LOCATELLI, Carla. Unwording the world. Samuel Beckett's prose works after the Nobel Prize. Philadelphia: University of Pennsylvania Press, 1990.

MORRISON, Kristin. Canters and Chronicles. The use of narrative in the plays of Samuel Beckett and Harold Pinter. Chicago: Chicago University Press, 1983

NAGEM, Monique. Know Happiness: Irony in Ill Seen Ill Said. In: Davis, Robin J \& Butler, Lance St. J. Make sense who may. Essays on 
Samuel Beckett's Later Works. Totowa, New Jersey: Barnes \& Noble Books, 1989.

NIXON, Mark. Samuel Beckett's German Diaries (1936-1937). London: Continuum, 2011.

NIXON, Mark \& FELDMAN, Matthew. The International Reception of Samuel Beckett. London/New York: Continuum, 2009.

OPPENHEIM, Lois. (Ed). Directing Beckett. Michigan: University of Michigan Press, 1997.

PERLOFF, Marjorie. Between Verse and Prose: Beckett and the New Poetry. In: Critical Inquiry. Vol. 9, n.2. Chicago: University of Chicago Press, dec 1982.

- Space of a Door: Beckett and the Poetry of Absense. In: Poetics of Indeterminacy. Rimbaud to Cage. Evanston, Illinois: Northwestern University Press, 1999.

. Une voix pas la mienne: French/English Beckett and the French/English reader. In: FRIEDMAN, Alan W. ROSSMAN, Charles \& SHERZER, Dina (Ed.) Beckett Translating/Translating Beckett. Pennsylvania State University Press, 1987.

PILLING, John. Samuel Beckett's More Pricks than Kicks: In a Strait of Two Wills. London: Bloomsbury, 2011.

RABINOVITZ, Rubin. The Self Contained: Beckett's fiction in the 1960s. In: ACHESON, James \& ARTHUR, Kateryna. Beckett's Later Fiction and Drama. Texts for Company. London: Macmillan Press, 1987.

READ, David. Beckett's Search for Unseeable and Unmakeable: Company and Ill Seen Ill Said. In: Modern Fiction Studies, Vol. 29, n.1, Spring 1983.

SMITH, Frederick N. Beckett's Eighteenth Century. Great Britain: Palgrave/Macmillan Press, 2002. 
SOUZA, Ana Helena. A tradução como um outro original. Como é de Samuel Beckett. Rio de Janeiro: 7letras, 2006.

SCHWARTZ, Adriano. A tendência autobiográfica do romance contemporâneo. Coetzee, Roth, Piglia. In: Novos Estudos Cebrap, n. 95, março 2013.

VILA-MATAS. Dublinesca. Trad. José Rubens Siqueira. São Paulo: Cosac Naify, 2011.

WEST, Sarah. Say it. The performative voice in the dramatic works of Samuel Beckett. Amsterdam/New York: Rodopi, 2010.

WOOLF, Virginia. Mr. Bennett and Mrs. Brown. Londres: Hogarth Press, 1924.

. Craftsmanship. In: The Death of the Moth and other essays. Orlando, Florida: Harcourt Brace \& Company, 1942.

ZILLIACUS, Clas. Beckett and broadcasting: a study of the works of Samuel Beckett for and in radio and television. Abo: Abo Akademi, 1976.

Sites:

www.apieceofmonologue.com

DVD:

Film (1965). Direção: Alan Schneider. Roteiro: Samuel Beckett. EUA, Magnus Opus. 